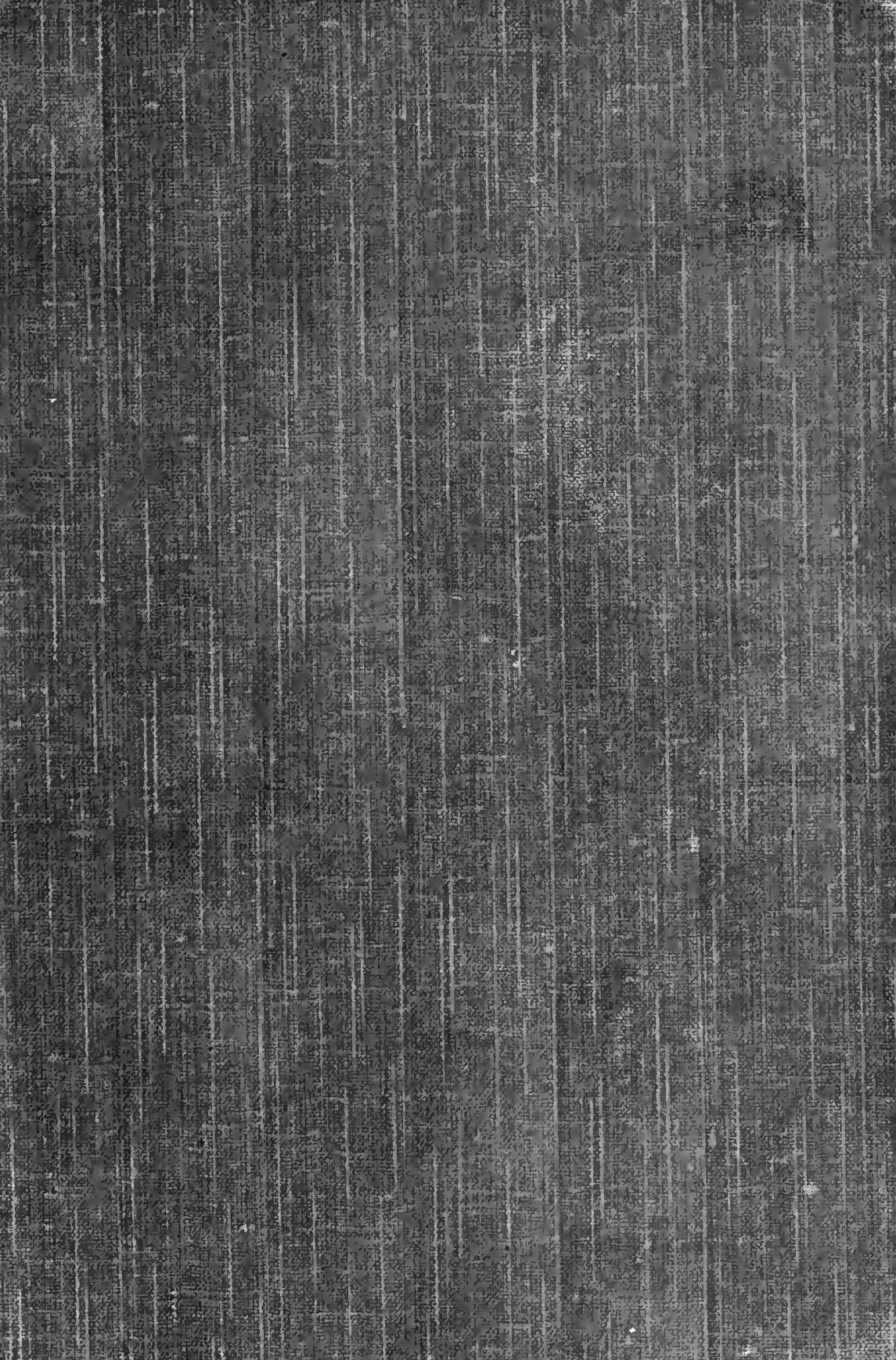



Mary Lascetles

* *... "fune ${ }^{3} 3 \%$.

- R.Sule

Novembur 1926 


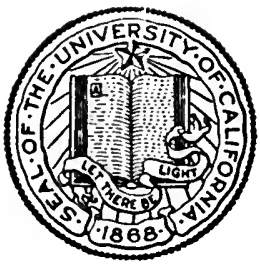

THE LIBRARY

OF

THE UNIVERSITY

OF CALIFORNIA

LOS ANGELES 
Mary Lascettes

* F fune ly3.

- R.Suale

Novembu 1926 


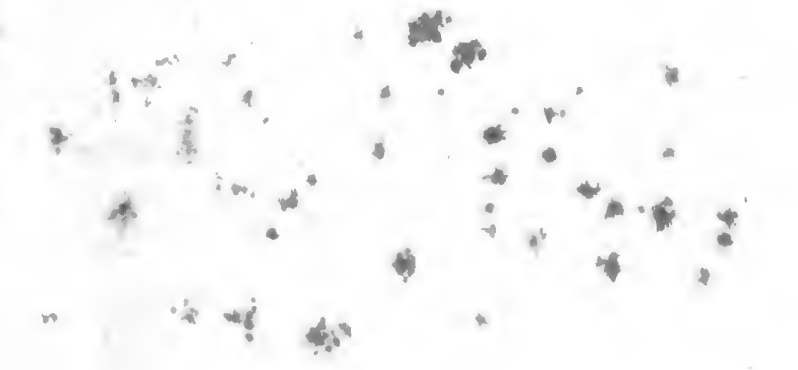

Digitized by the Internet Archive in 2007 with funding from. Microsoft Corporation
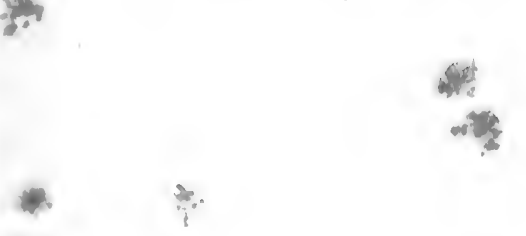

*
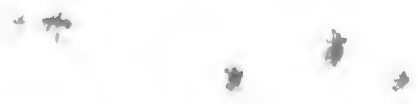

http://www.archive.org/details/poeticalworksofr01 bridiala 


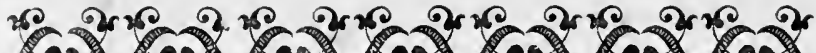
cos ev cos cos cos cos cos

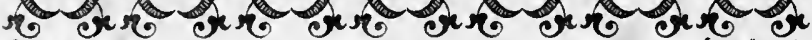
का. Q

c) के

(a)

(\$) c. क. (a) (8?

c. क. (6) 89 Volume I

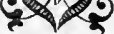
क. (8) ( 82 c.

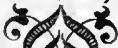
$(8)$ (S) \& 2 (2) (8) c. के (87) +2. (1) (Q⿻)

Poetical Works

ROBERT BRIDGES (8) (⿻) (\$2)

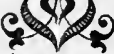

के

London

Smith, Elder \& Co I5 Waterloo Place 1898

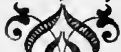

(s)

\%

(d)

(P)

$\%$

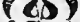

(8)

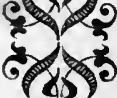

$(02$

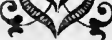
62

(8)

c. 128

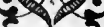

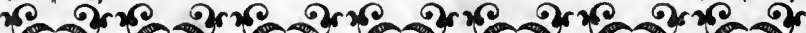

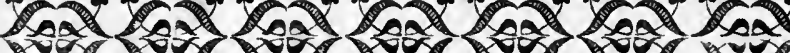

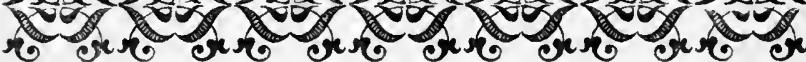


OXFORD: HORACE HART PRINTER TO THE UNIVERSITY 


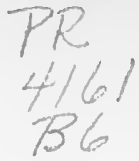

จ०.

$$
\begin{gathered}
\text { POETICAL WORKS OF } \\
\text { ROBERT BRIDGES }
\end{gathered}
$$

$$
\begin{gathered}
\text { VOLUME THE FIRST } \\
\text { CONT AINING }
\end{gathered}
$$

PROMETHEUS THE FIREGIVER • • p. I EROS AND PSTCHE . . . . . 7 I THE GROWTH OF LOVE . . . . 217 NOTES . . . . . . . $\quad . \quad 289$

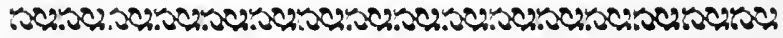




\section{LIST OF PREVIOUS EDITIONS}

\section{PROMETHEUS.}

I. Private Press of H. Daniel. Oxford, 1883.

2. Chiswick Press. Geo. Bell छ Sons, 1884 .

EROS AND PSYCHE.

I. Chiswick Press. Geo. Bell E Sons, 1885 .

2. Do. do. Revised, 1894 .

This last volume is still on sale.

\section{GROWTH OF LOVE.}

I. XXIV Sonnets. Ed. Bumpus, 1876 .

2. LXXIX Sonnets. Daniel Press, 1889 .

This edition was copied in America.

3. Do. do. Black letter. 1890. . 


\title{
PR OMETHEUS THE
}

FIR E G I E R

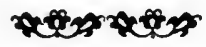

\author{
A MASK IN THE \\ GREEK MANNER
}

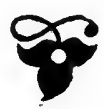




$$
\text { , }
$$




\section{ARGUMENT}

PROMETHEUS COMING ON EARTH TO GIVE FIRE TO MEN APPEARS BEFORE THE PALACE OF INACHUS IN ARGOS ON A FESTIVAL OF ZEUS - HE INTERRUPTS THE CEREMONY BY ANNOUNCING FIRE AND PERSUADES INACHUS TO DARE THE ANGER OF ZEUS AND ACCEPT THE GIFT - INACHUS FETCHING ARGEIA HIS WIFE FROM THE PALACE HAS IN TURN TO QUIET HER FEARS - HE ASKS A PROPHECY OF PROMETHEUS WHO FORETELLS THE FATE OF IO THEIR DAUGHTER - PROMETHEUS THEN SETTING FLAME TO THE ALTAR AND WRITING HIS OWN NAME THEREON IN THE PLACE OF ZEUS DISAPPEARS

THE CHORUS SING (I) A HYMN TO ZEUS WITH THE STORIES OF THE BIRTH OF ZEUS AND THE MARRIAGE OF HERA WITH THE DANCES OF THE CURETES AND THE HESPERIDES (2) THEIR ANTICIPATION OF FIRE WITH AN ODE ON WONDER (3) A TRAGIC HYMN ON THE LOT OF MAN (4) A FIRE-CHORUS (5) A FINAL CHORUS IN PRAISE OF PROMETHEUS

ALL THE CHARACTERS ARE GOOD - PROMETHEUS PROLOGIZES - HE CARRIES A LONG REED 


\title{
DRAMATIS PERSONÆ
}

\section{PROMETHEUS.}

\author{
INACHUS. \\ $A R G E I A$. \\ SERVANT. \\ IO (persona muta).
}

cHORUS: Youtbs and maidens of the bouse of

Inachus.

The SCENE is in ARGOS before the palace of Inachus.

An altar inscribed to Zeus is at the centre of the stage. 


\section{PROMETHEUS \\ THE FIREGIVER}

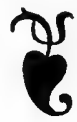

\section{PROMETHEUS.}

$F^{R O M}$ high Olympus and the ætherial courts,

Where mighty Zeus our angry king confirms

The Fates' decrees and bends the wills of the gods,

I come: and on the earth step with glad foot.

This variegated ocean-floor of the air,

The changeful circle of fair land, that lies

Heaven's dial, sisterly mirror of night and day :

The wide o'er-wandered plain, this nether world

My truant haunt is, when from jealous eyes

I steal, for hither 'tis I steal, and here

Unseen repair my joy: yet not unseen

Methinks, nor seen unguessed of him I seek.

Rather by swath or furrow, or where the path Is walled with corn I am found, by trellised vine 
Or olive set in banks or orchard trim :

I watch all toil and tilth, farm, field and fold, And taste the mortal joy; since not in heaven Among our easeful gods hath facile time A touch so keen, to wake such love of life As stirs the frail and careful being, who here,

The king of sorrows, melancholy man,

Bows at his labour, but in heart erect

A god stands, nor for any gift of god

Would barter his immortal-hearted prime.

Could I but win this world from Zeus for mine, With not a god to vex my happy rule, I would inhabit here and leave high heaven: So much I love it and its race of men, Even as he hates them, hates both them, and me For loving what he bates, and would destroy me, Outcast in the scorn of all his cringing crew, For daring but to save what he would slay: And me must first destroy. Thus he denieth My heart's wish, thus my counsel sets at naught, Which him saved once, when all at stake he stood Uprisen in rebellion to overthrow The elderseated Titans, for I that day Gave him the counsels which his foes despised. Unhappy they, who had still their blissful seats Preserved and their Olympian majesty, 
Had they been one with me. Alas, my kin!

But he, when he had taken the throne and chained His foes in wasteful Tartarus, said no more Where is Prometheus our wise counsellor? What saith Prometheus? tell us, O Prometheus, What Fate requires! but waxing confident And wanton, as a youth first tasting power, He wrecked the timeless monuments of heaven, The witness of the wisdom of the gods, And making all about him new, beyond Determined to destroy the race of men, And that create afresh or else have none.

Then his vain mind imagined a device, And at his bidding all the opposèd winds Blew, and the scattered clouds and furlèd snows, From every part of heaven together flying, He with brute hands in huge disorder heaped: They with the winds' weight and his angry breath Were thawed: in cataracts they fell, and earth In darkness deep and whelmèd tempest lay, 60 Drowned'neath the waters. Yet on the mountain-tops Some few escaped, and some, thus warned by me, Made shift to live in vessels which outrode The season and the fury of the flood.

And when his rain was spent and from clear skies Zeus looking down upon the watery world, 
Beheld these few, the remnant of mankind, Who yet stood up and breathed; he next withdrew The seeds of fire, that else had still Jain hid In withered branch and the blue flakes of fint 70 For man to exact and use, but these withdrawn, Man with the brutes degraded would be man No more; and so the tyrant was content.

But I, despised again, again upheld The weak, and pitying them sent sweet Hope, Bearer of dreams, enchantress fond and kind, From heaven descending on the unhindered rays Of every star, to cheer with visions fair Their unamending pains. And now this day Behold I come bearing the seal of all

Which Hope had promised : for within this reed

A prisoner I bring them stolen from heaven, The flash of mastering fire, and it have borne So swift to earth, that when yon noontide sun Rose from the sea at morning I was by, And unperceived of Hêlios plunged the point I' the burning axle, and withdrew a tongue Of breathing flame, which lives to leap on earth For man the father of all fire to come.

And hither have I brought it even to Argos

Unto king Inachus, him having chosen Above all mortals to receive my gift: 
For he is hopeful, careful, wise, and brave.

He first, when first the floods left bare the land,

Grew warm with enterprise, and gathered men Together, and disposed their various tasks

For common weal combined; for soon were seen The long straight channels dwindling on the plain, Which slow from stagnant pool and wide morass The pestilent waters to the rivers bore: Ion Then in the ruined dwellings and old tombs He dug, unbedding from the wormèd ooze Vessels and tools of trade and husbandry; Wherewith, all seasonable works restored, Oil made he and wine anew, and taught mankind To live not brutally though without fire, Tending their flocks and herds and weaving wool, Living on fruit and milk and shepherds' fare, Till time should bring back flame to smithy and hearth,

Or Zeus relent. Now at these gates I stand, I IO At this mid hour, when Inachus comes forth To offer sacrifice unto his foe.

For never hath his faithful zeal forborne To pay the power, though hard, that rules the world The smokeless sacrifice; which first today Shall smoke, and rise at heaven in flame to brave The baffled god. See here a servant bears 
For the cold altar ceremonial wood: My shepherd's cloak will serve me for disguise.

\section{SERVANT.}

With much toil have I hewn these sapless logs. I 20 Pr. But toil brings health, and health is happiness. Serv. Here's one I know not-nay, how came he here

Unseen by me? I pray thee, stranger, tell me What would'st thou at the house of Inachus?

Pr. Intruders, friend, and travellers have glib tongues,

Silence will question such.

Serv.

If 'tis a message,

To-day is not thy day-who sent thee hither?

Pr. 'The business of my leisure was well guessed: But he that sent me hither is I that come.

Serv. I smell the matter-thou would'st serve the house? 130

Pr. 'Twas for that very cause I fled my own. Serv. From cruelty or fear of punishment?

Pr. Cruel was my master, for he slew his father. His punishments thou speakest of are crimes.

Serv. Thou dost well flying one that slew his father. Pr. Thy lord, they say, is kind.

Serv.

Well, thou wilt see. 
Thou may'st at once begin-come, give a hand.

$\operatorname{Pr}$. A day of freedom is a day of pleasure;

And what thou doest have I never done,

And understanding not might mar thy work.

140

Serv. Ay true-there is a right way and a wrong In laying wood.

Pr. Then let me see thee lay it:

The sight of a skill'd hand will teach an art.

serv. Thou seest this faggot which I now unbind,

How it is packed within.

Pr. I see the cones

And needlcs of the fir, which by the wind

In melancholy places ceaselessly

Sighing are strewn upon the tufted floor.

Serv. These took I from a sheltered bank, whereon

The sun looks down at noon; for there is need

The things be dry. These first I spread; and then Small sticks that snap i' the hand.

Pr.

Such are enough

To burden the slow flight of labouring rooks,

When on the leafless tree-tops in young March

Their glossy herds assembling soothe the air

155

With cries of solemn joy and cawings loud.

And such the long-necked herons will bear to mend Their airy platform, when the loving spring 
Bids them take thought for their expected young.

Serv. See even so I cross them and cross them so:

Larger and by degrees a steady stack

Have built, whereon the heaviest logs may lie :

And all of sun-dried wood: and now 'tis done.

Pr. And now 'tis done, what means it now 'tis done?

Serv. Well, thus 'tis rightly done: but why 'tis so I cannot tell, nor any man here knows; Save that our master when he sacrificeth, As thou wilt hear anon, speaketh of fire; And fire he saith is good for gods and men; And the gods have it and men have it not: And then he prays the gods to send us fire; And we, against they send it, must have wood Laid ready thus as I have shewn thee here. Pr. To-day he sacrificeth? Serv. Ay, this noon.

Hark! hear'st thou not? they come. The solemn flutes Warn us away; we must not here be seen In these our soilèd habits, yet may stand Where we may hear and see and not be seen.

[Exeunt $R$. 
Enter CHORUS, and from the palace INACHUs bearing cakes: he comes to stand bebind the altar.

\section{CHORUS.}

God of Heaven!

We praise thee, Zeus most high, 180

To whom by eternal Fate was given

The range and rule of the sky;

When thy lot, first of three

Leapt out, as sages tell,

And won Olympus for thee,

Therein for ever to dwell :

But the next with the barren sea

To grave Poseidôn fell,

And left fierce Hades his doom, to be

The lord and terror of hell.

(2) Thou sittest for aye

Encircled in azure bright,

Regarding the path of the sun by day,

And the changeful moon by night:

Attending with tireless ears

To the song of adoring love,

With which the separate spheres

Are voicèd that turn above :

And all that is hidden under

The clouds thy footing has furl'd 
Fears the hand that holdeth the thunder, The eye that looks on the world.

Semichorus of youtbs.

Of all the isles of the sea

Is Crete most famed in story :

Above all mountains famous to me

Is Ida and crowned with glory.

There guarded of Heaven and Earth

Came Rhea at fall of night

To hide a wondrous birth

From the Sire's unfathering sight.

The halls of Cronos rang

With omens of coming ill,

And the mad Curêtes danced and sang

Adown the slopes of the hill.

Then all the peaks of Gnossus kindled red Beckoning afar unto the sinking sun, He thro' the vaporous west plunged to his bed, Sunk, and the day was done. But they, though he was fled,

Such light still held, as oft

Hanging in air aloft,

At eve from shadowed ship

The Egyptian sailor sees:

Or like the twofold tip 
That o'er the topmost trees

Flares on Parnassus, and the Theban dames

Quake at the ghostly flames.

Then friendly night arose

To succour Earth, and spread

Her mantle o'er the snows

And quenched their rosy red;

But in the east upsprings

Another light on them,

Selêné with white wings

And hueless diadem.

Little could she befriend

Her father's house and state,

Nor her weak beams defend

Hypérion from his fate.

Only where'er she shines,

In terror looking forth,

She sees the wailing pines

Stoop to the bitter North:

Or searching twice or thrice

Along the rocky walls,

She marks the columned ice

Of frozen waterfalls :

But still the darkened cave

Grew darker as she shone, 
Wherein was Rhea gone

s

Her child to bear and save.

[They dance.

Then danced the Dactyls and Curêtes wild, And drowned with yells the cries of mother and child;

Big-armed Damnámeneus gan prance and shout:

And burly Acmon struck the echoes out:

And Kermis leaped and howled : and Titias pranced: And broad Cyllenus tore the air and danced :

While deep within the shadowed cave at rest

Lay Rhea, with her babe upon her breast.

\section{IN ACHUS.}

If any here there be whose impure hands

Among pure hands, or guilty heart among

Our guiltless hearts be stained with blood or wrong, Let him depart!

If there be any here in whom high Zeus

Seeing impiety might turn away,

Now from our sacrifice and from his $\sin$

Let him depart!

\section{Semichorus of maidens.}

$I$ have chosen to praise

Hêra the wife, and bring

A hymn for the feast on marriage days 
To the wife of the gods' king.

How on her festival

The gods had loving strife,

Which should give of them all

The fairest gift to the wife. But Earth said, Fair to see Is mine and yields to none,

I have grown for her joy a sacred tree,

With apples of gold thereon.

Then Hêra, when she heard what Earth had given, Smiled for her joy, and longed and came to see :

On dovewings flying from the height of heaven,

Down to the golden tree :

As tired birds at even

Come flying straight to house

On their accustomed boughs.

'Twas where, on tortured hands

Bearing the mighty pole,

Devoted Atlas stands:

And round his bowed head roll

Day-light and night, and stars unmingled dance,

Nor can he raise his glance.

She saw the rocky coast

Whereon the azured waves 
Are laced in foam, or lost

In water-lighted caves;

The olive island where,

Amid the purple seas

Night unto Darkness bare

The four Hesperides:

And came into the shade

Of Atlas, where she found

The garden Earth had made

And fenced with groves around.

And in the midst it grew

Alone, the priceless stem,

As careful, clear and true

As graving on a gem.

Nature had kissèd Art

And borne a child to stir

With jealousy the heart

Of heaven's Artificer.

From crown to swelling root

It mocked the goddess' praise,

The green enamelled sprays

The emblazoned golden fruit.

[They dance.

And 'neath the tree, with hair and zone unbound, The fair Hesperides aye danced around, And Ægle danced and sang ' $O$ welcome, Queen!' 
And Erytheia sang ' The tree is green!'

And Hestia danced and sang 'The fruit is gold!'

And Arethusa sang 'Fair Queen, behold!'

And all joined hands and danced about the tree,

And sang ' $O$ Queen, we dance and sing for thee!'

In. If there be any here who has complaint Against our rule or claim or supplication,

Now in the name of Zeus let it appear,

Now let him speak!

\section{Prometbeus reenters.}

Pr. All hail, most worthy king, such claim have I. In. May grace be with thee, stranger; speak thy mind.

Pr. To Argos, king of Argos, at thy house I bring long journeying to an end this hour, Bearing no idle message for thine ears. For know that far thy fame has reached, and men That ne'er have seen thee tell that thou art set Upon the throne of virtue, that good-will And love thy servants are, that in thy land Joy, honour, trust and modesty abide And drink the air of peace, that kings must see Thy city, would they know their peoples' good $34^{\circ}$ And stablish them therein by wholesome laws. But one thing mars the tale, for o'er thy lands 
Travelling I have not seen from morn till eve, Either from house or farm or labourer's cot, In any village, nor this town of Argos

A blue-wreathed smoke arise: the hearths are cold, This altar cold: I see the wood and cakes Unbaken-O king, where is the fire?

In. If hither, stranger, thou wert come to find That which thou findest wanting, join with us Now in our sacrifice, take food within, And having learnt our simple way of life Return unto thy country whence thou camest. But hast thou skill or knowledge of this thing, How best it may be sought, or by what means Hope to be reached, O speak! I wait to hear.

$\operatorname{Pr}$. There is, $\mathrm{O}$ king, fire on the earth this day. In. On earth there is fire thou sayest!

Pr.

There is fire.

In. On earth this day!

Pr. There is fire on earth this day.

In. This is a sacred place, a solemn hour,

Thy speech is earnest : yet even if thou speak truth,

$\mathrm{O}$ welcome messenger of happy tidings, And though I hear aright, yet to believe Is hard: thou canst not know what words thou speakest

Into what ears : they never heard before 
This sound but in old tales of happier times, In sighs of prayer and faint unhearted hope: Maybe they heard not rightly, speak again!

$\mathrm{Pr}$. There is, $\mathrm{O}$ king, fire on the earth this day. In. Yes, yes, again. Now let sweet Music blab Her secret and give o'er; here is a trumpet 371 That mocks her method. Yet 'tis but the word. Maybe thy fire is not the fire I seek; Maybe though thou didst see it, now 'tis quenched, Or guarded out of reach : speak yet again And swear by heaven's truth is there fire or no; And if there be, what means may make it mine.

$\operatorname{Pr}$. There is, O king, fire on the earth this day: But not as thou dost seek it to be found.

In. How seeking wrongly shall I seek aright?

Pr. Thou prayest here to Zeus, and him thou callest

Almighty, knowing he could grant thy prayer : That if 'twere but his will, the journeying sun Might drop a spark into thine outstretched hand: That at his breath the splashing mountain brooks That fall from Ornex, and cold Lernè's pool Would change their element, and their chill streams Bend in their burning banks a molten flood: That at his word so many messengers Would bring thee fire from heaven, that not a hearth 
In all thy land but straight would have a god

To kneel and fan the flame : and yet to him,

It is to him thou prayest.

\section{In. Therefore to him.}

Pr. Is this thy wisdom, king, to sow thy seed Year after year in this unsprouting soil ? Hast thou not proved and found the will of Zeus A barren rock for man with prayer to plough?

In. His anger be averted! we judge not god Evil, because our wishes please him not. Oft our shortsighted prayers to heaven ascending Ask there our ruin, and are then denied 40 I In kindness above granting: were't not so, Scarce could we pray for fear to pluck our doom Out of the merciful withholding hands.

Pr. Why then provokest thou such great goodwill In long denial and kind silence shown?

In. Fie, fie! Thou lackest piety: the god's denial Being nought but kindness, there is hope that he Will make that good which is not:-or if indeed Good be withheld in punishment, 'tis well Still to seek on and pray that god relent.

Pr. O Sire of Argòs, Zeus will not relent.

In. Yet fire thou sayst is on the earth this day.

Pr. Not of his knowledge nor his gift, $\mathrm{O}$ king. In. By kindness of what god then has man fire? 
Pr. I say but on the earth unknown to Zeus.

In. How boastest thou to know, not of his knowledge?

Pr. I boast not: he that knoweth not may boast. In. Thy daring words bewilder sense with sound.

Pr. I thought to find thee ripe for daring deeds. In. And what the deed for which I prove unripe? Pr. To take of heaven's fire. In. And were I ripe, What should I dare, beseech you?

$\mathrm{Pr}$.

The wrath of Zeus.

In. Madman, pretending in one hand to hold The wrath of god and in the other fire.

$\mathrm{Pr}$. Thou meanest rather holding both in one.

In. Both impious art thou and incredible.

Pr. Yet impious only till thou dost believe.

In. And what believe? Ah, if I could believe!

It was but now thou saidst that there was fire,

And I was near believing; I believed:

Now to believe were to be mad as thou.

Chorus. He may be mad and yet say true-maybe The heat of prophecy like a strong wine Shameth his reason with exultant speech.

Pr. Thou say'st I am mad, and of my sober words Hast called those impious which thou fearest true, Those which thou knowest good, incredible. 
Consider ere thou judge: be first assured All is not good for man that seems god's will. See, on thy farming skill, thy country toil Which bends to aid the willing fruits of earth,

And would promote the seasonable year, The face of nature is not always kind: And if thou search the sum of visible being To find thy blessing featured, 'tis not there:

Her best gifts cannot brim the golden cup Of expectation which thine eager arms Lift to her mouthèd horn - what then is this Whose wide capacity outbids the scale Of prodigal beauty, so that the seeing eye And hearing ear, retiring unamazed Within their quiet chambers, sit to feast With dear imagination, nor look forth As once they did upon the varying air ? Whence is the fathering of this desire Which mocks at fated circumstance? nay though Obstruction lie as cumbrous as the mountains, Nor thy particular hap hath armed desire Against the brunt of evil, - yet not for this Faints man's desire : it is the unquenchable Original cause, the immortal breath of being : Nor is there any spirit on Earth astir, Nor 'neath the airy vault, nor yet beyond 
In any dweller in far-reaching space,

Nobler or dearer than the spirit of man :

That spirit which lives in each and will not die,

That wooeth beauty, and for all good things

Urgeth a voice, or in still passion sigheth,

And where he loveth draweth the heart with him.

Hast thou not heard him speaking oft and oft,

Prompting thy secret musing and now shooting

His feathered fancies, or in cloudy sleep

Piling his painted dreams? O hark to him!

For else if folly shut his joyous strength

To mope in her dark prison without praise,

The hidden tears with which he wails his wrong

Will sour the fount of life. O hark to him!

Him mayst thou trust beyond the things thou seest.

For many things there be upon this earth

Unblest and fallen from beauty, to mislead

Man's mind, and in a shadow justify

The evil thoughts and deeds that work his ill;

Fear, hatred, lust and strife, which, if man question

The heavenborn spirit within him, are not there.

Yet are they bold of face, and Zeus himself,

486

Seeing that Mischief held her head on high,

Lest she should go beyond his power to quell

And draw the inevitable Fate that waits

On utmost ill, himself preventing Fate 
Hasted to drown the world, and now would crush Thy little remnant: but among the gods

Is one whose love and courage stir for thee;

Who being of manlike spirit, by many shifts

Has stayed the hand of the enemy, who crieth

Thy world is not destroyed, thy good shall live :

Thou hast more power for good than Zeus for ill,

More courage, justice, more abundant art,

More love, more joy, more reason : though around thee Rank-rooting evil bloom with poisonous crown, Though wan and dolorous and crooked things $50 \mathrm{r}$ Have made their home with thee, thy good shall live.

Know thy desire: and know that if thou seek it, And seek, and seek, and fear not, thou shalt find.

Sem. (youtbs). Is this a god that speaketh thus?

sem. (maidens). He speaketh as a man

In love or great affliction yields his soul.

In. Thou, whencesoe'er thou comest, whoe'er thou art,

Who breakest on our solemn sacrifice

With solemn words, I pray thee not depart

Till thou hast told me more. This fire I seek 510 Not for myself, whose thin and silvery hair Tells that my toilsome age nears to its end, But for my children and the aftertime, 
For great the need thereof, wretched our state;

Nay, set by what has been, our happiness

Is very want, so that what now is not

Is but the measure of what yet may be.

And first are barest needs, which well I know

Fire would supply, but I have hope beyond,

That Nature in recovering her right

Would kinder prove to man who seeks to learn

Her secrets and unfold the cause of life.

So tell me, if thou knowest, what is fire?

Doth earth contain it? or, since from the sun

Fire reaches us, since in the glimmering stars

And pallid moon, in lightning, and the glance

Of tracking meteors that at nightfall show

How in the air a thousand sightless things

Travel, and ever on their windswift course

Flame when they list and into darkness go,- 530

Since in all these a fiery nature dwells,

Is fire an airy essence, a thing of heaven,

That, could we poise it, were an alien power

To make our wisdom less, our wonder more?

Pr. Thy wish to know is good, and happy is he

Who thus from chance and change has launched his mind

To dwell for ever with undisturbèd truth.

This high ambition doth not prompt his hand 
To crime, his right and pleasure are not wronged By folly of his fellows, nor his eye

Dimmed by the griefs that move the tears of men.

Son of the earth, and citizen may be

Of Argos or of Athens and her laws,

But still the eternal nature, where he looks,

O'errules him with the laws which laws obey,

And in her heavenly city enrols his heart.

In. Thus ever have I held of happiness,

The child of heavenly truth, and thus have found it

In prayer and meditation and still thought,

And thus my peace of mind based on a floor

That doth not quaver like the joys of sense :

Those I possess enough in seeing my slaves

And citizens enjoy, having myself

Tasted for once and put their sweets away.

But of that heavenly city, of which thou sayest

Her laws o'errule us, have I little learnt,

For when my wandering spirit hath dared alone

The unearthly terror of her voiceless halls,

She hath fallen from delight, and without guide

Turned back, and from her errand fled for fear. 560

Pr. Think not that thou canst all things know, nor deem

Such knowledge happiness: the all-knowing Fates

No pleasure have, who sit eternally 
Spinning the unnumbered threads that Time hath woven,

And weaves, upgathering in his furthest house To store from sight; but what 'tis joy to learn Or use to know, that may'st thou ask of right.

$I n$. Then tell me, for thou knowest, what is fire?

$\operatorname{Pr}$. Know then, O king, that this fair earth of men, The Olympus of the gods, and all the heavens Are lesser kingdoms of the boundless space 571 Wherein Fate rules; they have their several times, Their seasons and the limit of their thrones, And from the nature of eternal things Springing, themselves are changed; even as the trees Or birds or beasts of earth, which now arise To being, now in turn decay and die.

The heaven and earth thou seest, for long were held By Fire, a raging power, to whom the Fates Decreed a slow diminishing old age, 580 But to his daughter, who is that gentle goddess,

Queen of the clear and azure firmament, In heaven called Hygra, but by mortals Air, To her, the child of his slow doting years, Was given a beauteous youth, not long to outlast His life, but be the pride of his decay, And win to gentler sway his lost domains. And when the day of time arrived, when Air 
Took o'er from her decrepit sire the third Of the Sun's kingdoms, the one-moonèd earth, Straight came she down to her inheritance.

Gaze on the sun with thine unshaded eye And shrink from what she saw. Forests of fire Whose waving trunks, sucking their fuel, reared In branched flame roaring, and their torrid shades Aye underlit with fire. The mountains lifted And fell and followed like a running sea, And from their swelling flanks spumed froth of fire; Or, like awakening monsters, mighty mounds Rose on the plain awhile.

Sem. (maidens).

He discovers a foe. 600 Sem. (youths). An enemy he paints. Pr. These all she quenched,

Or charmed their fury into the dens and bowels Of earth to smoulder, there the vital heat To hold for her creation, which then-to her aid Summoning high Reason from his home in heaven,She wrought anew upon the temperate lands.

Sem. (maidens). 'Twas well Air won this kingdom of her sire.

Sem. (youtbs). Now say how made she green this home of fire.

Pr. The waters first she brought, that in their streams 
And pools and seas innumerable things

Brought forth, from whence she drew the fertile seeds

Of trees and plants, and last of footed life,

That wandered forth, and roaming to and fro,

The rejoicing earth peopled with living sound.

Reason advised, and Reason praised her toil;

Which when she had done she gave him thanks, and said,

'Fair comrade, since thou praisest what is done,

Grant me this favour ere thou part from me:

Make thou one fair thing for me, which shall suit

With what is made, and be the best of all.'

620

'Twas evening, and that night Reason made man.

Sem. (maidens). Children of Air are we, and live by fire.

Sem. (youtbs). The sons of Reason dwelling on the earth.

Sem. (maidens). Folk of a pleasant kingdom held between

Fire's reign of terror and the latter day

When dying, soon in turn his child must die.

Sem. (youtbs). Having a wise creator, above time Or youth or change, from whom our kind inherit The grace and pleasure of the eternal gods.

In. But how came gods to rule this earth of Air?

Pr. They also were her children who first ruled, 
Cronos, Iapetus, Hypérion,

Theia and Rhea, and other mighty names

That are but names-whom Zeus drave out from heaven,

And with his tribe sits on their injured thrones.

1n. There is no greater god in heaven than he.

Pr. Nor none more cruel nor more tyrannous.

In. But what can man against the power of god?

Pr. Doth not man strive with him? thyself dost pray.

In. That he may pardon our contrarious deeds.

Pr. Alas! alas! what more contrarious deed,

What greater miracle of wrong than this,

642

That man should know his good and take it not?

To what god wilt thou pray to pardon this?

In vain was reason given, if man therewith

Shame truth, and name it wisdom to cry down

The unschooled promptings of his best desire.

The beasts that have no speech nor argument

Confute him, and the wild hog in the wood

That feels his longing, hurries straight thereto, 650 And will not turn his head.

In.

How mean'st thou this?

$P r$. Thou hast desired the good, and now canst feel How hard it is to kill the heart's desire.

In. Shall Inachus rise against Zeus, as he 
Rose against Cronos and made war in heaven?

Pr. I say not so, yet, if thou didst rebel,

The tongue that counselled Zeus should counsel thee. Sem. (maidens). This is strange counsel.

Sem. (youtbs).

$\mathrm{He}$ is not

A counsellor for gods or men.

In. O that I knew where I might counsel find,

That one were sent, nay, were 't the least of all

The myriad messengers of heaven, to me!

662

One that should say ' This morn I stood with Zeus,

He hath heard thy prayer and sent me : ask a boon,

What thing thou wilt, it shall be given thee.'

Pr. What wouldst thou say to such a messenger?

In. No need to ask then what I now might ask,

How 'tis the gods, if they have care for mortals,

Slubber our worst necessities_-and the boon,

No need to tell him that.

Pr.

Now, king, thou seest

Zeus sends no messenger, but I am here.

In. Thy speech is hard, and even thy kindest words

Unkind. If fire thou hast, in thee 'tis kind

To proffer it : but thou art more unkind

Yoking heaven's wrath therewith. Nay, and how

knowest thou

675

Zeus will be angry if I take of it? 
Thou art a prophet : ay, but of the prophets Some have been taken in error, and honest time Has honoured many with forgetfulness.

I'll make this proof of thee; Show me thy fireNay, give't me now-if thou be true at all, Be true so far: for the rest there's none will lose, Nor blame thee being false-where is thy fire?

$\mathrm{Pr}$. O rather, had it thus been mine to give, I would have given it thus : not adding aught Of danger or diminishment or loss; So strong is my goodwill; nor less than this My knowledge, but in knowledge all my power. Yet since wise guidance with a little means Can more than force unminded, I have skill To conjure evil and outcompass strength. Now give I thee my best, a little gift To work a world of wonder; 'tis thine own Of long desire, and with it I will give The cunning of invention and all arts

In which thy hand instructed may command, Interpret, comfort, or ennoble nature; With all provision that in wisdom is, And what prevention in foreknowledge lies. In. Great is the gain. Pr.

O king, the gain is thine,

The penalty I more than share. 
In.

Enough,

I take thy gift; nor hast thou stood more firm To every point of thy strange chequered tale, Revealing, threatening, offering more and more, And never all, than I to this resolve.

Pr. I knew thy heart would fail not at the hour.

In. Nay, failed I now, what were my years of toil More than the endurance of a harnessed brute,

Flogged to his daily work, that cannot view The high design to which his labour steps? And I of all men were dishonoured most Shrinking in fear, who never shrank from toil, And found abjuring, thrusting stiffly back, The very gift for which I stretched my hands. What though I suffer? are these wintry years Of growing desolation to be held As cherishable as the suns of spring? Nay, only joyful can they be in seeing Long hopes accomplished, long desires fulfilled. And since thou hast touched ambition on the side Of nobleness, and stirred my proudest hope, And wilt fulfil this, shall I count the cost? Rather decay will triumph, and cold death Be lapped in glory, seeing strength arise From weakness, from the tomb go forth a flame. Pr. 'Tis well; thou art exalted now, the grace 
Becomes thy valiant spirit.

In.

Lo! on this day

Which hope despaired to see, hope manifests

A vision bright as were the dreams of youth;

When life was easy as a sleeper's faith

Who swims in the air and dances on the sea;

When all the good that scarce by toil is won,

Or not at all is won, is as a flower

Growing in plenty to be plucked at will :

Is it a dream again or is it truth,

This vision fair of Greece inhabited?

A fairer sight than all fair Iris sees,

Footing her airy arch of colours spun

From Ida to Olympus, when she stays

To look on Greece and thinks the sight is fair;

Far fairer now, clothed with the works of men.

$P r$. Ay, fairer far: for nature's varied pleasaunce Without man's life is but a desert wild,

Which most, where most she mocks him, needs his aid.

She knows her silence sweeter when it girds

745

His murmurous cities, her wide wasteful curves

Larger beside his economic line;

Or what can add a mystery to the dark,

As doth his measured music when it moves

With rhythmic sweetness through the void of night?

Nay, all her loveliest places are but grounds 
Of vantage, where with geometric hand,

True square and careful compass he may come

To plan and plant and spread abroad his towers,

His gardens, temples, palaces and tombs.

And yet not all thou seest, with trancèd eye Looking upon the beauty that shall be, The temple-crownèd heights, the wallèd towns, Farms and cool summer seats, nor the broad ways That bridge the rivers and subdue the mountains, Nor all that travels on them, pomp or war Or needful merchandise, nor all the sails Piloting over the wind-dappled blue Of the summer-soothed Ægean, to thy mind Can picture what shall be: these are the face And form of beauty, but her heart and life Shall they be who shall see it, born to shield A happier birthright with intrepid arms, To tread down tyranny and fashion forth A virgin wisdom to subdue the world, To build for passion an eternal song, To shape her dreams in marble, and so sweet Their speech, that envious Time hearkening shall stay In fear to snatch, and hide his rugged hand. Now is the birthday of thy conquering youth, O man, and lo! thy priest and prophet stand Beside the altar and have blessed the day. 
In. Ay, blessed be this day. Where is thy fire? Or is aught else to do, ere I may take?

$\mathrm{Pr}$. This was my message, speak and there is fire. In. There shall be fire. Await me here awhile. I go to acquaint my house, and bring them forth.

[Exit.

Cborus.

Hearken, O Argos, hearken!

There will be fire.

And thou, O Earth, give ear!

There will be fire.

Sem. (maidens). Who shall be sent to fetch this fire for the king?

Sem. (youtbs). Shall we put forth in boats to reap, And shall the waves for harvest yield The rootless flames that nimbly leap Upon their ever-shifting field?

sem. (maidens). Or we in olive-groves go shake And beat the fruiting sprays, till all The silv'ry glitter which they make Beneath into our baskets fall ?

Sem. (youtbs). To bind in sheaves and bear away The white unshafted darts of day?

Sem. (maidens). And from the shadow one by one Pick up the playful oes of sun? 
Sem. (youtbs). Or wouldst thou mine a passage deep Until the darksome fire is found, $80 \mathrm{I}$

Which prisoned long in seething sleep

Vexes the caverns underground?

Sem. (maidens). Or bid us join our palms perchance, To cup the slant and chinkèd beam, Which mounting morn hath sent to dance Across our chamber while we dream?

Sem. (youths). Say whence and how shall we fetch this fire for the king ?

Our hope is impatient of vain debating.

Sem. (maidens). My heart is stirred at the name of the wondrous thing, 810 And trembles awaiting.

\section{ODE.}

A coy inquisitive spirit, the spirit of wonder, Possesses the child in his cradle, when mortal things Are new, yet a varied surface and nothing under. It busies the mind on trifles and toys and brings Her grasp from nearer to further, from smaller to greater,

And slowly teaches flight to her fledgeling wings.

Where'er she flutters and falls surprises await her: She soars, and beauty's miracles open in sight, 
The flowers and trees and beasts of the earth; and later 820

The skies of day, the moon and the stars of night; 'Neath which she scarcely venturing goes demurely, With mystery clad, in the awe of depth and height.

O happy for still unconscious, for ah! how surely, How soon and surely will disenchantment come, When first to herself she boasts to walk securely, And drives the master spirit away from his home;

Seeing the marvellous things that make the morning Are marvels of every-day, familiar, and some Have lost with use, like earthly robes, their adorning, As earthly joys the charm of a first delight, $\quad 8_{3} \mathrm{I}$ And some are fallen from awe to neglect and scorning;

Until-

O tarry not long, dear needed sprite! Till thou, though uninvited, with fancy returnest To hallow beauty and make the dull heart bright: To inhabit again thy gladdened kingdom in earnest; Wherein-

from the smile of beauty afar forecasting The pleasure of god, thou livest at peace and yearnest With wonder everlasting. 


\section{SECOND PART.}

\section{Reenter from the palace INACHUs, with ARGEIA and Io.}

\section{IN ACHUS.}

THat but a small and easy thing now seems, Which from my house when I came forth at noon

A dream was and beyond the reach of man.

'Tis now a fancy of the will, a word,

Liberty's lightest prize. Yet still as one

Who loiters on the threshold of delight,

Delaying pleasure for the love of pleasure,

I dally-Come, Argeia, and share my triumph !

And set our daughter by thee; though her eyes

Are young, there are no eyes this day so young As shall forget this day-while one thing more I ask of thee; this evil, will it light

On me or on my house or on mankind?

Pr. Scarce on mankind, O Inachus, for Zeus A second time failing will not again Measure his spite against their better fate. And now the terror, which awhile o'er Earth 
Its black wings spread, shall up to Heaven ascend And gnaw the tyrant's heart: for there is whispered A word gone forth to scare the mighty gods;

How one must soon be born, and born of men, 860 Who shall drive out their impious host from heaven, And from their skyey dwellings rule mankind In truth and love. So scarce on man will fall This evil, nay, nor on thyself, $\mathrm{O}$ king;

Thy name shall live an honoured name in Greece. In. Then on my house 'twill be. Know'st thou no more?

Pr. Know I no more? Ay, if my purpose fail 'Tis not for lack of knowing: if I suffer, 'Tis not that poisonous fear hath slurred her task, Or let brave resolution walk unarmed. 870 My ears are callous to the threats of Zeus, The direful penalties his oath hath laid On every good that $I$ in heart and hand Am sworn to accomplish, and for all his threats, Lest their accomplishment should outrun mine, Am bound the more. Nay, nor his evil minions, Nor force, nor strength, shall bend me to his will.

\section{ARGEIA.}

Alas, alas, what heavy words are these, That in the place of joy forbid your tongue, 
That cloud and change his face, while desperate sorrow

880

Sighs in his heart? I came to share a triumph : All is dismay and terror. What is this?

In. True, wife, I spake of triumph, and I told thee The winter-withering hope of my whole life Has flower'd to-day in amaranth : what the hope Thou knowest, who hast shared; but the condition I told thee not and thou hast heard : this prophet, Who comes to bring us fire, hath said that Zeus Wills not the gift he brings, and will be wroth With us that take it.
Ar.
O doleful change, I came

In pious purpose, nay, I heard within

The hymn to glorious Zeus: I rose and said,

The mighty god now bends, he thrusts aside

His heavenly supplicants to hear the prayer

Of Inachus his servant; let him hear.

$O$ let him turn away now lest he hear.

Nay, frown not on me; though a woman's voice

That counsels is but heard impatiently,

Yet by thy love, and by the sons I bare thee,

By this our daughter, our last ripening fruit, $\quad 900$ By our long happiness and hope of more, Hear me and let me speak.

In.

Well, wife, speak on. 
Ar. Thy voice forbids more than thy words invite: Yet say whence comes this stranger. Know'st thou not?

Yet whencesoe'er, if he but wish us well, He will not bound his kindness in a day. Do nought in haste. Send now to Sicyon And fetch thy son Phorôneus, for his stake In this is more than thine, and he is wise. 'Twere well Phorôneus and Agialeus Were both here: maybe they would both refuse The strange conditions which this stranger brings. Were we not happy too before he came? Doth he not offer us unhappiness? Bid him depart, and at some other time, When you have well considered, then return.

In. 'Tis his conditions that we now shall hear.

$A r$. O hide them yet! Are there not tales enough Of what the wrathful gods have wrought on men? Nay, 'twas this very fire thou now would'st take, Which vain Salmoneus, son of Æolus, 921

Made boast to have, and from his rattling car Threw up at heaven to mock the lightning. Him The thunderer stayed not to deride, but sent One blinding fork, that in the vacant sky Shook like a serpent's tongue, which is but seen In memory, and he was not, or for burial 
Rode with the ashes of his royal city Upon the whirlwind of the riven air. And after him his brother Athamas, King of Orchomenos, in frenzy fell For Hera's wrath, and raving killed his son; And would have killed fair Ino, but that she fled Into the sea, preferring there to woo The choking waters, rather than that the arm Which had so oft embraced should do her wrong. For which old crimes the gods yet unappeased Demand a sacrifice, and the king's son Dreads the priest's knife, and all the city mourns. Or shall I say what shameful fury it was With which Poseidon smote Pasiphaë, But for neglect of a recorded vow : Or how Actæon fared of Artemis When he surprised her, most himself surprised: And even while he looked his boasted bow Fell from his hands, and through his veins there ran A strange oblivious trouble, darkening sense Till he knew nothing but a hideous fear Which bade him fly, and faster, as behind He heard his hounds give tongue, that through the wood 950 Were following, closing, caught him and tore him down. 
And many more thus perished in their prime; Lycaon and his fifty sons, whom Zeus In their own house spied on, and unawares Watching at hand, from his disguise arose, And overset the table where they sat Around their impious feast and slew them all : Alcyonè and Ceyx, queen and king, Who for their arrogance were changed to birds : And Cadmus now a serpent, once a king: $\quad 960$ And saddest Niobe, whom not the love Of Leto aught availed, when once her boast Went out, though all her crime was too much pride Of heaven's most precious gift, her children fair. Six daughters had she, and six stalwart sons; But Leto bade her two destroy the twelve. And somewhere now, among lone mountain rocks.

On Sipylus, where couch the nymphs at night Who dance all day by Achelous' stream, The once proud mother lies, herself a rock, 970 And in cold breast broods o'er the goddess' wrong.

In. Now hush thy fear. See how thou tremblest still. Or if thou fear, fear passion; for the freshes Of tenderness and motherly love will drown The eye of judgment : yet, since even excess Of the soft quality fits woman well, I praise thee; nor would ask thee less to aid 
With counsel, than in love to share my choice.

Tho' weak thy hands to poise, thine eye may mark

This balance, how the good of all outweighs 980

The good of one or two, though these be us.

Let not reluctance shame the sacrifice

Which in another thou wert first to praise.

$A r$. Alas for me, for thee and for our children,

Who, being our being, having all our having,

If they fare ill, our pride lies in the dust.

In. O deem not a man's children are but those

Out of his loins engendered-our spirit's love

Hath such prolific consequence, that Virtue

Cometh of ancestry more pure than blood,

And counts her seed as sand upon the shore.

Happy is he whose body's sons proclaim

Their father's honour, but more blest to whom

The world is dutiful, whose children spring

Out of all nations, and whose pride the proud

Rise to regenerate when they call him sire.

Ar. Thus, husband, ever have I bought and buy

Nobleness cheaply being linked with thee.

Forgive my weakness; see, I now am bold;

Tell me the worst, I'll hear and wish 'twere more.

In. Retire-thy tears perchance may stir again.

$A r$. Nay, I am full of wonder and would hear.

Pr. Bid me not tell if ye liave fear to hear; 
But have no fear. Knowledge of future things 1004 Can nothing change man's spirit: and though he seem To aim his passion darkly, like a shaft Shot toward some fearful sound in thickest night, He hath an owl's eye, and must blink at day. The springs of memory, that feed alike His thought and action, draw from furthest time Their constant source, and hardly brook constraint Of actual circumstance, far less attend On glassed futurity; nay, death itself, His fate unquestioned, his foretasted pain, The certainty foreknown of things unknown, Cannot discourage his habitual being 1016 In its appointed motions, to make waver His eager hand, nor loosen the desire Of the most feeble melancholy heart Even from the unhopefullest of all her dreams.

In. Since then I long to know, now something say Of what will come to mine when I am gone.

Pr. And let the maid too hear, for 'tis of her I speak, to tell her whither she should turn The day ye drive her forth from hearth and home. In. What sayst thou? drive her out? and we? from home? 1026

Banish the comfort of our eyes? Nay rather Believe that these obedient hands will tear 
The heart out of my breast, ere it do this.

Pr. When her wild cries arouse the house at night, And, running to her bed, ye see her sct

Upright in trancèd sleep, her starting hair

IO3 I

With deathly sweat bedewed, in horror shaking,

Her eyeballs fixed upon the unbodied dark,

Through which a draping mist of luminous gloom

Drifts from her couch away, - when, if asleep,

She walks as if awake, and if awake

Dreams, and as one who nothing hears or sees,

Lives in a sick and frantic mood, whose cause

She understands not or is loth to tell-

Ar. Ah, ah, my child, my child!-Dost thou feel aught?

I04I

Speak to me-nay, 'tis nothing-hearken not.

Pr. Ye then distraught with sorrow, neither knowing Whether to save were best or lose, will seek Apollo's oracle.

In. And what the answer?

Will it discover nought to avert this sorrow ?

Pr. Or else thy whole race perish root and branch. In. Alas! alas!

Pr. Yet shall she live though lost; from human form Changed, that thou wilt not know thy daughter more. In. Woe, woe! my thought was praying for her death.

IO5 I 
Pr. In Hera's temple shall her prison be At high Mycenæ, till from heaven be sent Hermes, with song to soothe and sword to slay The beast whose hundred eyes devour the door.

In. Enough, enough is told, unless indeed, The beast once slain, thou canst restore our child.

Pr. Nay, with her freedom will her wanderings Begin. Come hither, child-nay, let her come : What words remain to speak will not offend her, And shall in memory quicken, when she looks To learn where she should go;-for go she must, Stung by the venomous fly, whose angry flight She still will hear about her, till she come 1064 To lay her sevenfold-carried burden down Upon the Ethiop shore where he shall reign. In. But say-say first, what formPr. In snow-white hide Of those that feel the goad and wear the yoke. In. Round-hoofed, or such as tread with cloven foot?

Pr. Wide-horned, large-eyed, broad-fronted, and the feet I070

Cloven which carry her to her far goal.

In. Will that of all these evils be the term?

Pr. Ay, but the journey first which she must learn. Hear now, my child; the day when thou art free, 
Leaving the lion-gate, descend and strike The Trêtan road to Nemea, skirting wide The unhunted forest o'er the watered plain To walled Cleonæ, whence the traversed strcam To Corinth guides: there enter not, but pass To narrow Isthmus, where Poseidon won

A country from Apollo, and through the town

Of Crommyon, till along the robber's road Pacing, thy left eye meet the westcring sun O'er Geraneia, and thou reach the hill Of Megara, where Car thy brother's babe In time shall rule; next past Eleusis climb Stony Panactum and the pine-clad slopes Of Phyle; shun the left-hand way, and keep The rocks; the second day thy feet shall tread The plains of Græa, whence the roadway serves Aulis and Mycalessus to the point 109I Of vext Euripus : fcar not then the stream, Nor scenting think to taste, but plunging in Brcast its salt current to the further shore. For on this is'and mayst thou lose awhile Thy maddening pest, and rest and pasture find, And from the heafs of bold Macistus see The country left and sought: but when thou feel Thy torment urge, move down, recross the flood, And west by Harma's fencèd gap arrive 
At seven-gated Thebes : thy friendly goddess

Ongan Athenè has her seat without.

I 102

Chor. Now if she may not stay thy toilsome destined steps,

I pray that she may slay for thee the maddening fly.

Pr. Keep not her sanctuary long, but seek

Bootian Ascra, where the Muses' fount,

Famed Aganippè, wells: Ocalea

Pass, and Tilphusa's northern steeps descend

By Alalcomenæ, the goddess' town.

Guard now the lake's low shore, till thou have crossed Hyrcana and Cephissus, the last streams

I I I I

Which feed its reedy pools, when thou shalt come

Between two mountains that enclose the way

By peakèd $A b x$ to Hyampolis.

The right-hand path that thither parts the vale

Opes to Cyrtonè and the Locrian lands;

Toward Elateia thou, where o'er the marsh

A path with stones is laid; and thence beyond

To Thronium, Tarphè, and Thermopylæ,

Where rocky Lamia views the Maliac gulf.

Cbor. If further she should go, will she not see

That other Argos, the Dodonian land?

I 122

Pr. Crossing the Phthian hills thou next shalt reach Pharsalus, and Olympus' peakèd snows Shall guide thee o'er the green Pelasgic plains 
For many a day, but to Argissa come Let old Peneius thy slow pilot be Through Tempè, till they turn upon his left

Crowning the wooded slopes with splendours bare. Thence issuing forth on the Pierian shore Northward of Ossa thou shalt touch the lands Of Macedon.

Chor.

Alas, we wish thee speed,

But bid thee here farewell; for out of Greece Thou goest 'mongst the folk whose chattering speech Is like the voice of birds, nor home again Wilt thou return.

$\mathrm{Pr}$.

Thy way along the coast

Lies till it southward turn, when thou shalt seek Where wide on Strymon's plain the hindered flood Spreads like a lake; thy course to his oppose And face him to the mountain whence he comes: Which doubled, Thrace receives thee: barbarous names I I4I

Of mountain, town and river, and a people Strange to thine eyes and ears, the Agathyrsi, Of pictured skins, who owe no marriage law, And o'er whose gay-spun garments sprent with gold Their hanging hair is blue. Their torrent swim That measures Europe in two parts, and go Eastward along the sea, to mount the lands 
Beyond man's dwelling, and the rising steeps That face the sun untrodden and unnamed.- II 50

Know to earth's verge remote thou then art come, The Scythian tract and wilderness forlorn, Through whose rude rocks and frosty silences No path shall guide thee then, nor my words now: There as thou toilest o'er the treacherous snows, A sound then thou shalt hear to stop thy breath, And prick thy trembling ears; a far-off cry, Whose throat seems the white mountain and its passion The woe of earth. Flee not, nor turn not back : Let thine ears drink and guide thine eyes to see That sight whose terrors shall assuage thy terror, Whose pain shall kill thy pain. Stretched on the rock, Naked to scorching sun, to pinching frost, I $16_{3}$ To wind and storm and beaks of wingèd fiends From year to year he lies. Refrain to ask His name and crime-nay, haply when thou see him Thou wilt remember-'tis thy tyrant's foe, Man's friend, who pays his chosen penalty. Draw near, my child, for he will know thy need, And point from land to land thy further path.

\section{Cborus}

O miserable man, hear now the worst.

$O$ weak and tearful race, 
Born to unhappiness, see now thy cause

Doomed and accurst!

It surely were enough, the bad and good Together mingled, against chance and ill To strive, and prospering by turns,

Now these, now those, now folly and now skill,

Alike by means well understood

Or 'gainst all likelihood;

Loveliness slaving to the unlovely will

That overrides the right and laughs at law.

But always all in awe 1183

And imminent dread:

Because there is no mischief thought or said,

Imaginable or unguessed,

But it may come to be; nor home of rest,

Nor hour secure : but anywhere,

At any moment; in the air,

Or on the earth or sea,

Or in the fair

And tender body itself it lurks, creeps in,

Or seizes suddenly,

Torturing, burning, withering, devouring,

Shaking, destroying; till tormented life

Sides with the slayer, not to be, 
And from the cruel strife

Falls to fate overpowering.

Or if some patient heart,

In toilsome steps of duty tread apart,

1200

Thinking to win her peace within herself,

And thus awhile succeed:

She must see others bleed,

At others' misery moan,

And learn the common suffering is her own,

From which it is no freedom to be freed:

Nay, Nature, her best nurse,

Is tender but to breed a finer sense,

Which she may easier wound, with smart the worse

And torture more intense.'

And no strength for thee but the thought of duty,

Nor any solace but the love of beauty.

O Right's toil unrewarded!

O Love's prize unaccorded!

I say this might suffice,

$O$ tearful and unstable

And miserable man,

Were't but from day to day

Thy miserable lot, 
This might suffice, I say,

1220

To term thee miserable.

But thou of all thine ills too must take thought,

Must grow familiar till no curse astound thee,

With tears recall the past,

With tears the times forecast;

With tears, with tears thou hast

The scapeless net spread in thy sight around thee.

How then support thy fate,

O miserable man, if this befall,

That he who loves thee and would aid thee, daring

To raise an arm for thy deliverance,

1231

Must for his courage suffer worse than all?

In. Bravest deliverer, for thy prophecy

Has torn the veil which hid thee from my eyes,

If thyself art that spirit, of whom some things

Were darkly spoken,-nor can I doubt thou art,

Being that the heaven its fire withholds not from thee

Nor time his secrets,-tell me now thy name,

That I may praise thee rightly; and my late

Unwitting words pardon thou, and these who still

In blinded wonder kneel not to thy love.

I 24 I

Pr. Speak not of love. See, I am moved with hate, And fiercest anger, which will sometimes spur 
The heart to extremity, till it forget

That there is any joy save furious war.

Nay, were there now another deed to do,

Which more could hurt our enemy than this,

Which here I stand to venture, here would I leave thee

Conspiring at his altar, and fly off

To plunge the branding terror in his soul.

But now the rising passion of my will

Already jars his reaching sense, already

From heaven he bids his minion Hermes forth

To bring his only rebel to his feet.

Therefore no more delay, the time is short.

In. I take, I take. ' Tis but for thee to give.

Pr. O heavenly fire, life's life, the eye of day,

Whose nimble waves upon the starry night

Of boundless ether love to play,

Carrying commands to every gliding sprite

To feed all things with colour, from the ray

Of thy bright-glancing, white

And silver-spinning light :

Unweaving its thin tissue for the bow

Of Iris, separating countless hues

Of various splendour for the grateful flowers

To crown the hasting hours,

Changing their special garlands as they choose. 
$O$ spirit of rage and might,

Who canst unchain the links of winter stark, And bid earth's stubborn metals flow like oil,

Her porphyrous heart-veins boil;

Whose arrows pierce the cloudy shields of dark;

Let now this flame, which did to life awaken

Beyond the cold dew-gathering veils of morn,

And thence by me was taken,

And in this reed was borne,

A smothered theft and gift to man below,

Here with my breath revive,

Restore thy lapsèd realm, and be the sire

Of many an earthly fire.

O flame, flame bright and live, Appear upon the altar as I blow.

Chor. 'Twas in the marish reed.

See to his mouth he sets its hollow flute And breathes therein with heed,

As one who from a pipe with breathings mute Will music's voice evoke.-

See, the curl of a cloud.

In. The smoke, the smoke!

Semichorus. Thin clouds mounting higher.

In. 'Tis smoke, the smoke of fire. 
Semicborus. Thick they come and thicker,

Quick arise and quicker,

Higher still and higher.

Their wreaths the wood enfold.

-I see a spot of gold.

They spring from a spot of gold,

Red gold, deep among

The leaves: a golden tongue.

$\mathrm{O}$ behold, behold,

Dancing tongues of gold,

That leaping aloft flicker,

Higher still and higher.

In. 'Tis fire, the flame of fire!

Semicborus. The blue smoke overhead

Is turned to angry red.

The fire, the fire, it stirs.

Hark, a crackling sound,

As when all around

Ripened pods of furze

Split in the parching sun

Their dry caps one by one,

And shed their seeds on the ground.

-Ah! what clouds arise.

Away! O come away.

The wind-wafted smoke,

Blowing all astray, 
Blinds and pricks my eyes.

Ah! I choke, I choke.

-All the midst is rent :

See the twigs are all

[Prometheus, after writing his name on the altar, goes out unobserved.]

By the flaming spent

White and gold, and fall.

How they writhe, resist,

Blacken, flake, and twist,

Snap in gold and fall.

- See the stars that mount,

Momentary bright

Flitting specks of light

More than eye can count.

Insects of the air,

As in summer night

Show a fire in flying

Flickering here and there,

Waving past and dying.

-Look, a common cone

Of the mountain pine

Solid gold is grown;

Till its scales outshine,

Standing each alone

I 340

In the spiral rows

Of their fair design,

All the brightest shows 
Of the sun's decline.

-Hark, there came a hiss,

Like a startled snake

Sliding through the brake.

$\mathrm{Oh}$, and what is this?

Smaller flames that flee

Sidelong from the tree,

Hark, they hiss, they hiss.

- How the gay flames flicker,

Spurting, dancing, leaping

Quicker yet and quicker,

Higher yet and higher,

-Flaming, flaring, fuming,

Cracking, crackling, creeping,

Hissing and consuming :

Mighty is the fire.

In. Stay, stay, cease your rejoicings. Where is he, The prophet,-nay, what say $I$, - the god, the giver ?

chor. He is not here-he is gone.

In. Search, search around.

Search all, search well.

cbor. He is gone, -he is not here.

In. The palace gate lics open : go, Argeia, Maybe he went within : go seek him there.

[Exit Ar. 
Look down the sea road, down the ccuntry road: Follow him if ye see him.

chor.

$\mathrm{He}$ is not there.

In. Strain, strain your eyes: look well: search everywhere.

Look townwards-is he there?

Part of Chorus returning. He is not therc.Other part returning. $\mathrm{He}$ is not there.

Ar. re-entering. $\mathrm{He}$ is not there.

Chor. O see!

chor.

chor.

chor. What see ye on the altar?

Chor.

Here in front

Words newly writ.

chor. What words?

Chor.

In.
See where?

See on the altar-see! 
Prometheus-ay, Prometheus. Know ye, my children,

1382

This name we see was writ by him we seek.

'Tis his own name, his own heart-stirring name,

Feared and revered among the immortal gods;

Divine Prometheus: see how here the large

Cadmeian characters run, scoring out

The hated title of his ancient foe, -

To Zeus 'twas made, - and now 'tis to PrometheusWrit with the charrèd reed-theft upon theft.

He hath stolen from Zeus his altar, and with his fire Hath lit our sacrifice unto himself. 1392 Ió Prometheus, friend and firegiver,

For good or ill thy thefts and gifts are ours. We worshipped thee unknowing.

Chor.

But now where is he?

In. No need to search-we shall not see him more. We look in vain. The high gods when they choose Put on and off the solid visible shape Which more deceives our hasty sense, than when Seeing them not we judge they stand aloof. And he, he now is gone; his work is done: 'Tis ours to see it be not done in vain. 1402 Chor. What is to do? speak, bid, command, we fly. In. Go some and fetch more wood to feed the fire; And some into the city to proclaim 
That fire is ours : and send out messengers To Corinth, Sicyon, Megara and Athens And to Mycenæ, telling we have fire : And bid that in the temples they prepare Their altars, and send hither careful men To learn of me what things the time requires.

[Exit part of Chorus.

The rest remain to end our feast; and now Seeing this altar is no more to Zeus, 1413 But shall for ever be with smouldering heat Fed for the god who first set fire thereon, Change ye your hymns, which in the praise of Zeus Ye came to sing, and change the prayer for fire Which ye were wont to raise, to high thanksgiving, Praising aloud the giver and his gift.

Part of Chorus. Now our happy feast hath ending, While the sun in heaven descending

Sees us gathered round a light Born to cheer his vacant night. Praising him to-day who came Bearing far his heavenly flame: Came to crown our king's desire With his gift of golden fire.

Semicborus. My heart, my heart is freed. Now can I sing. I loose a shaft from my bow, 
A song from my heart to heaven, and watch it speed. It revels in the air, and straight to its goul doth go.

I have no fear: I praise distinguishing duly:

I praise the love that I love and I worship truly. Goodness I praise, not might,

Nor more will I speak of wrong,

But of lovingkindness and right;

And the god of my love shall rejoice at the sound of my song.

I praise him whom I have seen :

As a man he is beautiful, blending prime and youth, Of gentle and lovely mien,

With the step and the eyes of truth,

As a god,-O were I a god, but thus to be man!

As a god, I set him above

The rest of the gods; for his gifts are pledges of love,

The words of his mouth rare and precious,

His eyes' glance and the smile of his lips are love.

$\mathrm{He}$ is the one

I447

Alone of all the gods,

Of righteous Themis the lofty-spirited son,

Who hates the wrongs they have done.

$\mathrm{He}$ is the one $\mathrm{I}$ adore.

For if there be love in heaven with evil to cope,-

And he promised us more and more,-

For what may we not hope? 


\section{$O D E$}

My soul is drunk with joy, her new desire In far forbidden places wanders away.

Her hopes with free bright-coloured wings of fire Upon the gloom of thought

Are sailing out.

Awhile they rise, awhile to rest they softly fall,

Like butterflies, that flit

Across the mountains, or upon a wall

Winking their idle fans at pleasure sit.

\section{O my vague desires!}

Ye lambent flames of the soul, her offspring fires:

That are my soul herself in pangs sublime

Rising and flying to heaven before her time:

What doth tempt you forth

To melt in the south or shiver in the frosty north?

What seek ye or find ye in your random flying,

For ever soaring aloft, soaring and dying?

Joy, the joy of flight;

They hide in the sun, they flare and dance in the night.

Gone up, gone out of sight-and ever again

Follow fresh tongues of fire, fresh pangs of pain.

Ah! could I control

These vague desires, these leaping flames of the soul: 
Could I but quench the fire, ah! could I stay My soul that flieth, alas, and dieth away!

[Enter other part of Chorus.

Part of Chor. Here is wood to feed the fire-

Never let its flames expire.

Sing ye still while we advance

Round the fire in measured dance,

While the sun in heaven descending

Sees our happy feast have ending.

Weave ye still your joyous song,

While we bear the wood along.

Semichorus. But $\mathrm{O}$ return,

Return, thou flower of the gods!

Remember the limbs that toil and the hearts that yearn,

Remember, and soon return!

To prosper with peace and skill

Our hands in the works of pleasure, beauty and use.

Return, and be for us still

Our shield from the anger of Zeus.

And he, if he raise his arm in anger to smite thee, And think for the good thou hast done with pain to requite thee,

Vengeance I heard thee tell,

And the curse I take for my own, 


\section{THE FIREGIVER}

That his place is prepared in hell,

And a greater than he shall hurl him down from his throne.

Down, down from his throne!

For the god who shall rule mankind from the deathless skies

By mercy and truth shall be known,

In love and peace shall arise.

1505

For him,-if again I hear him thunder above,

$O$ then, if I crouch or start,

I will press thy lovingkindness more to my heart,

Remember the words of thy mouth rare and precious, Thy heart of hearts and gifts of divine love. 


\section{EROS}

A NARRATIVE POEM IN

TWELVE MEASURES

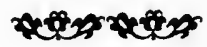

THE STORY DONE INTO ENGLISH FROM THE

LATIN OF APULEIUS 
L'anima semplicetta che sa nulla. DANTE

O latest-born, o loveliest vision far Of all Olympus' faded bierarcby.

REATS 


\title{
EROS ชு PSYCHE
}

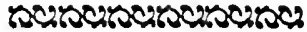 \\ FIRST QUARTER \\ S P R I N G \\ resscisciscrscises
}

PSYCHE'S EARTHLY PARENTAGE - WORSHIPPED BY MEN - \& PERSECUTED BY APHRODITE - SHE IS LOVED \& CARRIED OFF BY EROS

$$
\text { ऊै? }
$$





\section{EROS \& PSYCHE}

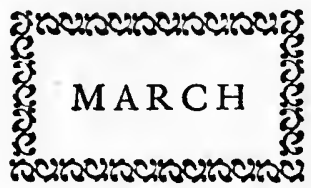

I

IN midmost length of hundred-citied Crete, The land that cradl'd Zeus, of old renown, Where grave Demeter nurseried her wheat, And Minos fashion'd law, ere he went down To judge the quaking hordes of Hell's domain, There dwelt a King on the Omphalian plain Eastward of Ida, in a little town.

2

Three daughters had this King, of whom my tale Time hath preserved, that loveth to despise The wealth which men misdeem of much avail, Their glories for themselves that they devise; For clerkly is he, old hard-featured Time, And poets' fabl'd song, and lovers' rhyme He storeth on his shelves to please his eyes. 
These three princesses all were fairest fair; And of the elder twain 'tis truth to say That if they stood not high above compare, Yet in their prime they bore the palm away; Outwards of loveliness; but Nature's mood, Gracious to make, had grudgingiy endued And marr'd by gifting ill the beauteous clay.

\section{4}

And being in honour they were well content To feed on lovers' looks and courtly smiles, To hang their necks with jewel'd ornament, And gold, that vanity in vain beguiles, And live in gaze, and take their praise for due, To be the fairest maidens then to view Within the shores of Greece and all her isles.

\section{5}

But of that youngest one, the third princess, There is no likeness; since she was as far From pictured beauty as is ugliness, Though on the side where heavenly wonders are, Ideals out of being and above, Which music worshipeth, but if love love, 'Tis, as the poet saith, to love a star. 


\section{6}

Her vision rather drave from passion's heart

What earthly soil it had afore possest;

Since to man's purer unsubstantial part

The brightness of her presence was addrest:

And such as mock'd at God, when once they saw

Her heavenly glance, were humbl'd, and in awe

Of things unseen, return'd to praise the Best.

\section{7}

And so before her, wheresoe'er she went, Hushing the crowd a thrilling whisper ran, And silent heads were reverently bent;

Till from the people the belief began

That Love's own mother had come down on earth, Sweet Cytherea, or of mortal birth A greater Goddess was vouchsaf't to man.

\section{8}

Then Aphrodite's statue in its place

Stood without worshippers; if Cretans pray'd For beauty or for children, love or grace, The prayer and vow were offer'd to the maid; Unto the maid their hymns of praise were sung, Their victims bled for her, for her they hung Garland and golden gift, and none forbade. 


\section{9}

And thence opinion spread beyond the shores, From isle to isle the wonder flew, it came Across the Ægræan on a thousand oars, Athens and Smyrna caught the virgin's fame; And East or West, where'er the tale had been, The adoration of the foam-born queen Fell to neglect, and men forgot her name.

IO

No longer to high Paphos now 'twas sail'd; The fragrant altar by the Graces served At Cnidus was forsaken; pilgrims fail'd The rocky island to her name reserved, Proud Ephyra, and Meropis renown'd; 'Twas all for Crete her votaries were bound, And to the Cretan maid her worship swerved.

\section{I}

Which when in heaven great Aphrodite saw, Who is the breather of the year's bright morn, Fount of desire and beauty without flaw, Herself the life that doth the world adorn; Seeing that without her generative might Nothing can spring upon the shores of light, Nor any bud of joy or love be born; 
12

She, when she saw the insult, did not hide

Her indignation, that a mortal frail

With her eterne divinity had vied,

Her fair Hellenic empire to assail,

For which she had fled the doom of Ninus old,

And left her wanton images unsoul'd

In Babylon and Zidon soon to fail.

\section{3}

'Not long,' she cried, 'shall that poor girl of Crete God it in my despite; for I will bring Such mischief on the sickly counterfeit As soon shall cure her tribe of worshipping: Her beauty will I mock with loathèd lust, Bow down her dainty spirit to the dust, And leave her long alive to feel the sting.'

\section{4}

With that she calls to her her comely boy, The limber scion of the God of War, The fruit adulterous, which for man's annoy To that fierce partner Cytherea bore, ERos, the ever young, who only grew In mischief, and was Cupid named anew In westering aftertime of latin lore. 
What the first dawn of manhood is, the hour When beauty, from its fleshy bud unpent, Flaunts like the corol of a summer flower, As if all life were for that ornament, Such Eros seemed in years, a trifler gay, The prodigal of an immortal day For ever spending, and yet never spent.

\section{6}

His skin is brilliant with the nimble flood Of ichor, that comes dancing from his heart, Lively as fire, and redder than the blood, And maketh in his eyes small flashes dart, And curleth his hair golden, and distilleth Honey on his tongue, and all his body filleth With wanton lightsomeness in every part.

\section{7}

Naked he goeth, but with sprightly wings Red, iridescent, are his shoulders fledged. A bow his weapon, which he deftly strings, And little arrows barb'd and keenly edged; And these he shooteth true; but else the youth For all his seeming recketh naught of truth, But most deceiveth where he most is pledged. 
I 8

'Tis he that maketh in men's heart a strife Between remorseful reason and desire, Till with life lost they lose the love of life, And by their own hands wretchedly expire; Or slain in bloody rivalries they miss Even the short embracement of their bliss, His smile of fury and his kiss of fire.

\section{I9}

He makes the strong man weak, the weak man wild; Ruins great business and purpose high; Brings down the wise to folly reconciled, And martial captains on their knees to sigh : He changeth dynasties, and on the head Of duteous heroes, who for honour bled, Smircheth the laurel that can never die.

20

Him then she call'd, and gravely kissing told The great dishonour to her godhead done; And how, if he from that in heaven would hold, On earth he must maintain it as her son; The rather that his weapons were most fit, As was his skill ordain'd to champion it; And flattering thus his ready zeal she won. 
Whereon she quickly led him down on earth, And show'd him PSYCHE, thus the maid was named; Whom when she show'd, but could not hide her worth,

She grew with envy tenfold more enflamed. 'But if,' she cried, 'thou smite her as I bid, Soon shall our glory of this affront be rid, And she and all her likes for ever shamed.

22

'Make her to love the loathliest, basest wretch, Deform'd in body, and of moonstruck mind, A hideous brute and vicious, born to fetch Anger from dogs and cursing from the blind. And let her passion for the monster be As shameless and detestable as he Is most extreme and vile of humankind.'

Which said, when he agreed, she spake no more, But left him to his task, and took her way Beside the ripples of the shell-strewn shore, The southward stretching margin of a bay, Whose sandy curves ste pass'd, and taking stand Upon its taper horn of furthest land, Lookt left and right to rise and set of day. 
Fair was the sight; for now, though full an hour The sun had sunk, she saw the evening light In shifting colour to the zenith tower, And grow more gorgeous ever and more bright. Bathed in the warm and comfortable glow, The fair delighted queen forgot her woe, And watch'd the unwonted pageant of the night.

\section{5}

Broad and low down, where late the sun had been, A wealth of orange-gold was thickly shed,

Fading above into a field of green, Like apples ere they ripen into red;

Then to the height a variable hue Of rose and pink and crimson freak'd with blue, And olive-border'd clouds o'er lilac led.

\section{6}

High in the opposèd west the wondering moon All silvery green in flying green was fleec't; And round the blazing South the splendour soon Caught all the heaven, and ran to North and East; And Aphrodite knew the thing was wrought By cunning of Poseidon, and she thought She would go see with whom he kept his feast.

$\dagger \quad \mathrm{G}_{2}$ 
Swift to her wish came swimming on the waves His lovely ocean nymphs, her guides to be, The Nereids all, who live among the caves And valleys of the deep, Cymodocè, Agavè, blue-eyed Hallia and Nesæa, Speio, and Thoë, Glaucè and Actæa, Iaira, Melitè and Amphinomè,

\section{8}

Apseudès and Nemertès, Callianassa,

Cymothoë, Thaleia, Limnorrhea,

Clymenè, Ianeira and Ianassa,

Doris and Panopè and Galatea,

Dynamenè, Dexamenè and Maira,

Ferusa, Doto, Proto, Callianeira,

Amphithö̈, Oreithuia and Amathea.

29

And after them sad Melicertes drave His chariot, that with swift unfellied wheel, By his two dolphins drawn along the wave, Flew as they plunged, yet did not dip nor reel, But like a plough that shears the heavy land Stood on the flood, and back on either hand O'erturn'd the briny furrow with its keel. 
30

Behind came Tritons, that their conches blew, Greenbearcied, tail'd like fish, all sleek and stark; And hippocampi tamed, a bristly crew, The browzers of old Proteus' weedy park, Whose chiefer Mermen brought a shell for boat, And balancing its hollow fan afloat, Push'd it to shore and bade the queen embark :

\section{I}

And then the goddess stept upon the shell Which took her weight; and others threw a train Of soft silk o'er her, that unfurl'd to swell In sails, at breath of flying Zephyrs twain; And all her way with foam in laughter strewn, With stir of music and of conches blown, Was Aphrodite launch'd upon the main.

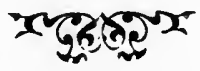




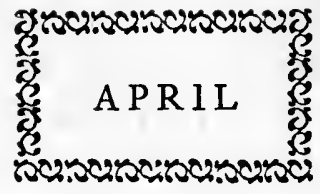

$\mathbf{I}$

BUT fairest Psyche still in favour rose,

Nor knew the jealous power against her sworn :

And more her beauty now surpass't her foe's,

Since 'twas transfigured by the spirit forlorn,

That writeth, to the perfecting of grace,

Immortal question in a mortal face,

The vague desire whereunto man is born.

2

Already in good time her sisters both,

Whose honest charms were never famed as hers,

With princes of the isle had plighted troth,

And gone to rule their foreign courtiers;

But she, exalted evermore beyond

Their loveliness, made yet no lover fond,

And gain'd but number to her worshippers. 


\section{APRIL}

3

To joy in others' joy had been her lot, And now that that was gone she wept to see How her transcendent beauty overshot The common aim of all felicity.

For love she sigh'd; and had some peasant rude For true love's sake in simple passion woo'd, Then Psyche had not scorn'd his wife to be.

\section{4}

For what is Beauty, if it doth not fire The loving answer of an eager soul? Since 'tis the native food of man's desire, And doth to good our varying world control; Which, when it was not, was for Beauty's sake Desired and made by Love, who still doth make A beauteous path thereon to Beauty's goal.

5

Should all men by some hateful venom die, The pity were that o'er the unpeopl'd sphere The sun would still bedeck the evening sky And the unimaginable hues appear, With none to mark the rose and gold and green; That Spring should walk the earth, and nothing seen

Of her fresh delicacy year by year. 
And if some beauteous things, - whose heavenly worth

And function overpass our mortal sense,-

Lie waste and unregarded on the earth

By reason of our gross intelligence,

These are not vain, because in nature's scheme

It lives that we shall grow from dream to dream

In time to gather an enchantment thence.

$$
7
$$

Even as we see the fairest works of men Awhile neglected, and the makers die; But Truth comes weeping to their graves, and then Their fames victoriously mounting high Do battle with the regnant names of eld, To win their seats; as when the Gods rebel'd Against their sires and drave them from the sky.

8

But to be praised for beauty and denied The meed of beauty, this was yet unknown : The best and bravest men have ever vied To win the fairest women for their own. Thus Psyche spake, or reason'd in her mind, Disconsolate; and with self-pity pined, In the deserted halls wandering alone. 


\section{A PRIL}

9

And grievèd grew the King to see her woe : And blaming first the gods for her disease, He purposed to their oracle to go To question how he might their wrath appease, Or, if that might not be, the worst to hear,Which is the last poor hope of them that fear.So he took his ship upon the northern seas,

\section{Io}

And journeying to the shrine of Delphi went, The temple of Apollo Pythian, Where when the god he question'd if 'twas meant That Psyche should be wed, and to what man, The tripod shook, and o'er the vaporous well The chanting Pythoness gave oracle, And thus in priestly verse the sentence ran:

I I

High on the topmost rock with funeral feast Convey and leave the maid, nor look to find A mortal busband, but a savage beast, The viperous scourge of gods and bumankind; Who shames and vexes all, and as be fies With sword and fire, Zeus trembles in the skies, And groans arise from souls to bell consign'd. 
I 2

With which reply the King return'd full sad : For though he nothing more might understand, Yet in the bitter bidding that he had No man made question of the plain command, That he must sacrifice the tender flower Of his own blood to a demonian power, Upon the rocky mount with his own hand.

\section{3}

Some said that she to Talos was devote, The metal giant, who with mile-long stride Cover'd the isle, walking around by rote Thrice every day at his appointed tide; Who shepherded the sea-goats on the coast, And, as be past, caught up and live would roast, Pressing them to his burning ribs and side :

\section{4}

Whose head was made of fine gold-beaten work, Of silver pure his arms and gleaming chest, Thence of green-b'oomèd bronze far as the fork, Of iron weather-rusted all the rest.

One single vein he had, which running down From head to foot was open in his crown, And closèd by a nail; such was this pest. 
15

A little while they spent in sad delay, Then order'd, as the oracle rad said, The cold feast and funereal display Wherewith the fated bridal should be sped: And their black pageantry and vain despairing When Psyche saw, and for herself preparing The hopeless ceremonial of the dead,

\section{6}

Then spake she to the King and said ' $O$ Sire, Why wilt thou veil those venerable eyes With piteous tears, which must of me require More tears again than for myself arise? Then, on the day my beauty first o'erstept Its mortal place it had been well to have wept; But now the fault beyond our ruing lies.

I 7

'As to be worship'd was my whole undoing, So my submission must the forfeit pay : And welcome were the morning of my wooing, Tho' after it should dawn no other day. Up to the mountain! for I hear the voice Of my belovèd on the winds, Rejoice, Arise, my love, my fair one, and come away!" 
With such distemper'd speech, that little cheer'd Her mourning house, she went to choose with care The raiment for her day of wedlock weird, Her body as for burial to prepare; But laved with bridal water, from the stream Where Hera bathed; for still her fate supreme Was doubtful, whether Love or Death it were :

\section{I9}

Love that is made of joy, and Death of fear : Nay, but not these held Psyche in suspense; Hers was the hope that following by the bier Boweth its head beneath the dark immense : Her fear the dread of life that turns to hide Its tragic tears, what hour the happy bride Ventures for love her maiden innocence.

\section{0}

They set on high upon the bridal wain Her bed for bier, and yet no corpse thereon; But like as when unto a warrior slain And not brought home the ceremonies done Are empty, for afar his body brave Lies lost, deep buried by the wandering wave, Or 'neath the foes his fury fell upon,- 


\section{I}

So was her hearse : and with it went afore, Singing the solemn dirge that moves to tears, The singers; and behind, clad as for war, The King uncrown'd among his mournful peers, All 'neath their armour robed in linen white; And in their left were shields, and in their right Torches they bore aloft instead of spears.

\section{2}

And next the virgin tribe in white forth sail'd, With wreaths of dittany; and 'midst them there Went Psyche, all in lily-whiteness veil'd, The white Quince-blossom chapleting her hair : And last the common folk, a weeping crowd, Far as the city-gates with wailings loud Follow'd the sad procession in despair.

\section{3}

Thus forth and up the mount they went, until The funeral chariot must be left behind, Since road was none for steepness of the hill; And slowly by the narrow path they wind: All afternoon their white and scatter'd file Toil'd on distinct, ascending many a mile Over the long brown slopes and crags unkind. 


\section{4}

But ere unto the snowy peak they came Of that stormshapen pyramid so high, 'Twas evening, and with footsteps slow and lame They gather'd up their lagging company : And then her sire, even as Apollo bade, Set on the topmost rock the hapless maid, With trembling hands and melancholy cry.

\section{5}

And now the sun was sunk; only the peak Flash'd like a jewel in the deepening blue : And from the shade beneath none cared to speak, But all look'd up, where glorified anew Psyche sat islanded in living day. Breathless they watcht her, till the last red ray Fled from her lifted arm that waved adicu.

\section{6}

There left they her, turning with sad farewells To haste their homeward course, as best they might: But night was crowding up the barren fells, And hid full soon their rocky path from sight; And each unto his stumbling foot to hold His torch was fain, for o'er the moon was roll'd A mighty cloud from heaven, to blot her light. 
And thro' the darkness for long while was seen That armour'd train with waving fires to thread Downwards, by pass, defile, and black ravine, Each leading on the way that he was led. Slowly they gain'd the plain, and one by one Into the shadows of the woods were gone, Or in the clinging mists were quench'd and fled.

\section{8}

But unto Psyche, pondering o’er her doom In tearful silence on her stony chair,

A Zephyr straying out of heaven's wide room Rush'd down, and gathering round her unaware Fill'd with his breath her vesture and her veil; And like a ship, that crowding all her sail Leans to accompany the tranquil air,

She yielded, and was borne with swimming brain And airy joy, along the mountain side, Till, hid from earth by ridging summits twain, They came upon a valiey deep and wide; Where the strong Zephyr with his burden sank, And laid her down upon a grassy bank, 'Mong thyme and vio'ets and daisies pied. 
And straight upon the touch of that sweet bed Both woe and wonder melted fast away: And sleep with gentle stress her sense o'erspread, Gathering as darkness doth on drooping day : And nestling to the ground, she slowly drew Her wearied limbs together, and, ere she knew, Wrapt in forgetfulness and slumber lay. 


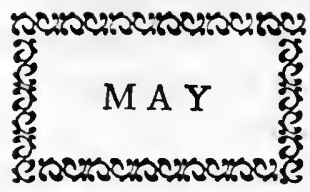

I

A FTER long sleep when Psyche first awoke Among the grasses 'neath the open skies, And heard the mounting larks, whose carol spoke Delighted invitation to arise, She lay as one who after many a league Hath slept off memory with his long fatigue, And waking knows not in what place he lies:

\section{2}

Anon her quickening thought took up its task, And all came back as it had happ'd o'ernight; The sad procession of the wedding mask, The melancholy toiling up the height, The solitary rock where she was left; And thence in dark and airy waftage reft, How on the flowers she had been disburden'd light. 
Thereafter she would rise and see what place That voyage had its haven in, and found She stood upon a little hill, whose base Shelved off into the valley all around; And all round that the steep cliffs rose away, Save on one side where to the break of day The widening dale withdrew in falling ground.

\section{4}

There, out from over sea, and scarce so high As she, the sun above his watery blaze Upbroke the grey dome of the morning sky, And struck the island with his level rays; Sifting his gold thro' lazy mists, that still Climb'd on the shadowy roots of every hill, And in the tree-tops breathed their silvery haze.

\section{5}

At hand on either side there was a wood; And on the upward lawn, that sloped between, Not many paces back a temple stood, By even steps ascending from the green; With shaft and pediment of marble made, It fill'd the passage of the rising glade, And there withstay'd the sun in dazzling sheen. 
Too fair for human art, so Psyche thought,

It might the fancy of some god rejoice;

Like to those halls which lame Hephæstos wrought,

Original, for each god to his choice,

In high Olympus; where his matchless lyre

Apollo wakes, and the responsive choir

Of Muses sing alternate with sweet voice.

\section{7}

Wondering she drew anigh, and in a while Went up the steps as she would entrance win, And faced her shadow 'neath the peristyle Upon the golden gate, whose flanges twinAs there she stood, irresolute at heart To try-swung to her of themselves apart; Whereat she past between and stood within.

8

A foursquare court it was with marble floor'd, Embay'd about with pillar'd porticoes, That echo'd in a somnolent accord The music of a fountain, which arose Sparkling in air, and splashing in its tank; Whose wanton babble, as it swell'd or sank, Gave idle voice to silence and repose. 
Thro' doors beneath the further colonnade, Like a deep cup's reflected glooms of gold, The inner rooms glow'd with inviting shade: And, standing in the court, she might behold Cedar, and silk, and silver; and that all The pargeting of ceiling and of wall Was fresco'd o'er with figures manifold.

10

Then making bold to go within, she heard Murmur of gentle welcome in her ear; And seeing none that coud have spoken word, She waited: when again $\mathbf{z l a d y}$, oraw near; Enter! was cried; and now more voices came From all the air around calling her name, And bidding her rejoice and have no fear.

\section{II}

And one, if she would rest, would show her bed, Pillow'd for sleep, with fragrant linen fine;

One, were she hungry, had a table spread Like as the high gods have it when they dine:

Or, would she bathe, were those would heat the bath;

The joyous cries contending in her path,

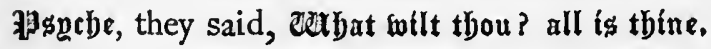




\section{2}

Then Psyche would have thank'd their service true, But that she fear'd her echoing words might scare Those sightless tongues; and well by dream she knew

The voices of the messengers of prayer, Which fly upon the gods' commandment, when They answer the supreme desires of men, Or for a while in pity hush their care.

I3

'Twas fancy's consummation, and because She would do joy no curious despite, She made no wonder how the wonder was; Only concern'd to take her full delight. So to the bath, - what luxury could be Better enhanced by eyeless ministry?She follows with the voices that invite.

\section{I4}

There being deliciously refresht, from soil Of earth made pure by water, fire, and air, They clad her in soft robes of Asian toil, Scented, that in her queenly wardrobe were; And led her forth to dine, and all around Sang as they served, the while a choral sound Of strings unseen and reeds the burden bare. 
15

$P$ athetic strains and passionate they wove,

$U$ rgent in ecstasies of beavenly sense;

$\mathbf{R}$ esponsive rivalries, that, while they strove,

$C$ ombined in full harmonious suspense,

E ntrancing wild desire, then fell at last

L ull'd in soft closes, and with gay contrast

$\mathrm{L}$ aunch'd forth their fresh unwearied excellence.

\section{6}

Now Psyche, when her twofold feast was o'er, Would feed her eye; and choosing for her guide A low-voiced singer, bade her come explore The wondrous house; until on every side As surfeited with beauty, and seeing nought But what was rich and fair beyond her thought, And all her own, thus to the voice she cried :

I 7

' Am I indeed a goddess, or is this

But to be dead; and through the gates of death Passing unwittingly doth man not miss Body nor memory nor living breath; Nor by demerits of his deeds is cast, But, paid with the desire he holdeth fast, Is holp with all his heart imagineth?' 


\section{I8}

But her for all reply the wandering tongue

Call'd to the chamber where her bed was laid,

With flower'd broideries of linen hung :

And round the walls in painting were portray'd

Love's victories over the gods renown'd.

Ares and Aphrodite here lay bound

In the fine net that dark Hephæstus made :

I9

Here Zeus, in likeness of a tawny bull,

Stoop'd on the Cretan shore his mighty knee,

While off his back Europa beautiful

Stept pale against the blue Carpathian sea;

And here Apollo, as he caught amazed

Daphne, for lo! her hands shot forth upraised

In leaves, her feet were rooted like a tree :

20

Here Dionysos, springing from his car At sight of Ariadne; here uplept Adonis to the chase, breaking the bar Of Aphrodite's arm for love who wept : He spear in hand, with leastèd dogs at strain; A marvellous work. But Psyche soon grown fain Of rest, betook her to her bed and slept. 
Nor long had slept, when at a sudden stir She woke; and one, that thro' the dark made way, Drew near, and stood beside; and over her The curtain rustl'd. Trembling now she lay, Fainting with terror: till upon her face A kiss, and with two gentle arms' embrace, $A$ voice that call'd her name in loving play.

\section{2}

Though for the darkness she coud nothing see, She wish'd not then for what the night denied: This was the lover she had lack'd, and she, Loving his loving, was his willing bride. O'erjoy'd she slept again, o'erjoy'd awoke At break of morn upon her love to look; When lo! his empty place lay by her side.

\section{3}

So all that day she spent in company Of the soft voices; and of riggt, they said, art tbou our 3 adon now. 23e bappily Tbn bridal morrofo by tbu serbants sped. But she but long'd for night, if that might bring Her lover back; and he on secret wing Came with the dark, and in the darkness fled. 


\section{4}

And this was all her life; for every night He came, and though his name she never learn'd, Nor was his image yielded to her sight At morn or eve, she neither look'd nor yearn'd Beyond her happiness : and custom brought An ease to pleasure; nor would Psyche's thought Have ever to her earthly home return'd,

\section{5}

But that one night he said 'Psyche, my soul, Sad danger threatens us : thy sisters twain Come to the mountain top, whence I thee stole, And thou wilt hear their voices thence complain. Answer them not: for it must end our love If they should hear or spy thee from above.' And Psyche said 'Their cry shall be in vain.'

\section{6}

But being again alone, she thought 'twas hard On her own blood; and blamed her joy as thief Of theirs, her comfort which their comfort barr'd; When she their care might be their care's relief. All day she brooded on her father's woe, And when at night her lover kisst her, lo! Her tender face was wet with tears of grief. 
Then question'd why she wept, she all confest; And begg'd of him she might but once go nigh To set her sire's and sisters' fears at rest;

Till he for pity coud not but comply : 'Only if they should ask thee of thy love Discover nothing to their ears above.' And Psyche said 'In vain shall be their cry.'

And yet with day no sooner was alone, Than she for loneliness her promise rued : That having so much pleasure for her own, 'Twas all unshared and spent in solitude. And when at night ler love flew to his place, More than afore she shamed his fond embrace, And piteously with tears her plaint renew'd.

The more he now denied, the more she wept; Nor would in anywise be comforted, Unless ker sisters, on the Zephyr swept, Should in those halls be one day bathed and fed, And see themselves the palace wlere she reign'd. And he by force of tears at last constrain'd, Granted her wish unwillingly, and said : 


\section{0}

'Much to our peril hast thou won thy will;

'Thy sisters' love, seeing thee honour'd so,

Will sour to envy, and with jealous skill

Will pry to learn the thing that none may know.

Answer not, nor inquire; for know that I

The day thou seest my face far hence shall fly,

And thou anew to bitterest fate must go.'

\section{I}

But Psyche said, 'Thy love is more than life;

To have thee leaveth nothing to be won:

For should the noonday prove me to be wife

Even of the beauteous Eros, who is son Of Cypris, I coud never love thee more.' Whereat he fondly kisst her o'er and o'er, And peace was 'twixt them till the night was done. 



\title{
EROS $ॄ$ PSYCHE
}

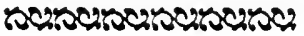 \\ SECOND QUARTER \\ S U M M E R \\ sersensisciscist
}

PSYCHE'S SISTERS - SNARING HER TO DESTRUCTION - ARE THEMSELVES DESTROYED

$$
\text { अृ }
$$




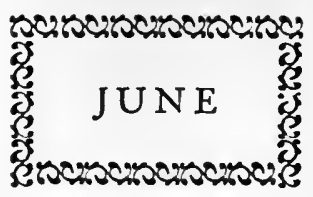

I

$A^{\text {ND truly need there was to the old King }}$ For consolation: since the mournful day

Of Psyche's fate he took no comforting, But only for a speedy death would pray; And on his head his hair grew silver-white. -Such on life's topmost bough is sorrow's blight, When the stout heart is cankering to decay.

Which when his daughters learnt, they both were quick

Comfort and solace to their sire to lend. But as not seldom they who nurse the sick Will take the malady from them they tend, So happ'd it now ; for they who fail'd to cheer Grew sad themselves, and in that palace drear Increased the evil that they came to mend. 
3

And them the unhappy father sent to seek Where Psyche had been left, if they might find What monster held her on the savage peak; Or if she there had died of hunger pined, And, by wild eagles stript, her scatter'd bones Might still be gather'd from the barren stones; Or if her fate had left no trace behind.

\section{4}

So just upon this time her sisters both Climb'd on the cliff that hung o'er Psyche's vale; And finding there no sign, to leave were loth Ere well assured she lurk'd not within hail. So calling loud her name, 'Psyche!' they cried, 'Psyche, O Psyche!' and when none replied They sank upon the rocks to weep and wail.

5

But Psyche heard their voices where she sat, And summoning the Zephyr bade him fleet Those mourners down unto the grassy plat 'Midst of her garden, where she had her seat. Then from the dizzy steep the wondering pair Came swiftly sinking on his buoyant air, And stood upon the terrace at her feet. 
Upsprang she then, and kiss'd them and embraced, And said ' Lo, here am I, I whom ye mourn. I am not dead, nor tortured, nor disgraced, But blest above all days since I was born : Wherefore be glad. Enter my home and see How little cause has been to grieve for me, And my desertion on the rocks forlorn.'

\section{7}

So entering by the golden gate, or e'er The marvel of their hither flight had waned, Fresh wonder took them now, for everywhere Their eyes that lit on beauty were enchain'd; And Psyche's airy service, as she bade, Perform'd its magic office, and display'd The riches of the palace where she reign'd.

\section{8}

And through the perfumed chambers they were led, And bathed therein; and after, set to sup, Were upon dreamlike delicacies fed, And wine more precious than its golden cup. 'Till seeing nothing lack'd and naught was theirs, Their happiness fell from them unawares, And bitter envy in their hearts sprang up. 
9

At last one said ' Psyche, since not alone Thou livest here in joy, as well we wot, Who is the man who should these wonders own, Or god, I say, and still appeareth not? What is his name? What rank and guise hath he, Whom winds and spirits serve, who honoureth thee Above all others in thy blissful lot??

\section{IO}

But Psyche when that wistful speech she heard Was ware of all her spouse had warn'd her of : And uttering a disingenuous word, Said ' A youth yet unbearded is my love; He goeth hunting on the plains to-day, And with his dogs hath wander'd far away; And not till eve can he return above.'

\section{I}

Then fearing to be nearer plied, she rose And brought her richest jewels one by one, Bidding them choose and take whate'er they chose; And beckoning the Zephyr spake anon That he should waft her sisters to the peak; The which ke did, and, ere they more coud speak, They rose on high, and in the wind were gone. 
I 2

Nor till again they came upon the road, Which from the mountain shoulder o'er the plain Led to the city of their sire's abode,

Found they their tongues, though full of high disdain Their hearts were, but kept silence, till the strength Of pride and envious hatred burst at length In voice, and thus the elder gan complain :

\section{3}

'Cruel and unjust fortune! that of three Sisters, whose being from one fountain well'd, Exalts the last so high from her degree, And leaves the first to be so far excel'd. My husband is a poor and niggard churl To him, whoe'er he be, that loves the girl. $\mathrm{Oh}$ ! in what godlike state her house is held!'

14

'Ay,' said the other, ' to a gouty loon Am I not wedded? Lo! thy hurt is mine : But never call me woman more, if soon I cannot lure her from her height divine. Nay, she shall need her cunning wit to save The wealth of which so grudgingly she gave; Wherefore thy hand and heart with me combine. 
I5

'She but received us out of pride, to show Her state, well deeming that her happiness Was little worth while there was none to know;

So is our lot uninjured if none guess.

Reveal we nothing therefore, but the while Together scheme this wanton to beguile, And bring her boasting godhead to distress.'

\section{I6}

So fresh disordering their dress and hair, With loud lament they to their sire return, Telling they found not Psyche anywhere, And of her sure mischance could nothing learn : And with that lie the wounded man they slew, Hiding the saving truth which well they knew; Nor did his piteous grief their heart concern.

\section{I7}

Meanwhile her unknown lover did not cease To warn poor Psyche how her sisters plan'd To undermine her love and joy and peace; And urged how well she might their wiles withstand, By keeping them from her delight aloof: For better is security than proof, And malice held afar than near at hand. 
18

'And, dearest wife,' he said, 'since 'tis not long Ere one will come to share thy secrecy, And be thy babe and mine; let nothing wrong The happy months of thy maternity. If thou keep trust, then shalt thou see thy child A god; but if to pry thou be beguiled, The lot of both is death and misery.'

I9

Then Psyche's simple heart was fill'd with joy, And counting to herself the months and days, Look'd for the time, when she should bear a boy To be her growing stay and godlike praise. And ' $O$ be sure,' she said, 'be sure, my pride Having so rich a promise cannot slide, Even if my love coud fail which thee obeys.'

20

And so most happily her life went by, In thoughts of love dear to her new estate; Until at length the evil day drew nigh, When now her sisters, joined in jealous hate, Set forth again, and plotted by the way How they might best allure her to betray Her secret; with what lie their angle bait. 
That night her husband spake to her, and said 'Psyche, thy sisters come : and when they climb The peak they will not tarry to be sped Down by the Zephyr, as that other time, But winging to the wind will cast themselves Out in the air, and on the rocky shelves Be dasht, and pay the penalty of crime.

'So let it be, and so shall we be saved.' Which meditated vengeance of his fear When Psyche heard, now for their life she craved, Whose mere distress erewhile had toucht her near. Around her lover's neck her arms she threw, And pleaded for them by her faith so true, Although they went on doom in judgment clear.

\section{3}

In terror of bloodguiltiness she now Forgot all other danger; she adjured; Or using playfulness deep sobs would plow Her soft entreaties, not to be endured : Till he at last was fain once more to grant The service of the Zephyr, to enchant That wicked couple from their fate assured. 


\section{4}

So ere 'twas noon were noises at the door Of knocking loud and voices high in glee;

Such as within that vale never before

Had been, and now seem'd most unmeet to be. And Psyche blush'd, though being alone, and rose To meet her sisters and herself unclose

The gate that made them of her palace free.

\section{5}

Fondly she kiss'd them, and with kindly cheer Sought to amuse; and they with outward smile O'ermask'd their hate, and called her sweet and dear,

Finding affection easy to beguile:

And all was smooth, until at last one said

' Tell us, I pray, to whom 'tis thou art wed;

'Mong gods or men, what is his rank and style?

\section{6}

'Thou canst not think to hide the truth from us, Who knew thy peevish sorrows when a maid, And see thee now so glad and rapturous, As changed from what thou wert as light from shade; Thy jewels, too, the palace of a king,

Nor least the serviceable spiriting, By everything thy secret is betray'd : 


\section{EROS छ PSYCHE}

27

' And yet thou talkest of thy wondrous man No more than if his face thou didst not know.' At which incontinently she began, Forgetful of her word a month ago, Answering ' A merchant rich, of middle age, My husband is; and o'er his features sage His temples are already touch'd with snow.

\section{8}

'But 'gainst his wish since hither ye were brought 'Twere best depart.' Then her accustom'd spell Sped them upon the summit quick as thought; And being alone her doing pleased her well : So was she vext to find her love at night More sad than ever, of her sisters' spite Speaking as one that coud the end foretell.

29

'And ere long,' said he, 'they will spy again : Let them be dash'd upon the rocks and die; 'Tis they must come to death or thou to pain, To separation, Psyche, thou and I; Nay, and our babe to ill. I therefore crave Thou wilt not even once more these vipers save, Nor to thy love his only boon deny.' 


\section{JUNE}

\section{0}

But Psyche would not think her sisters' crime So gross and strange, nor coud her danger see;

Since 'twere so easy, if at any time

They show'd the venom of their hearts, that she Should fan them off upon the willing gust. So she refused, and claiming truer trust, Would in no wise unto their death agree.

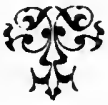




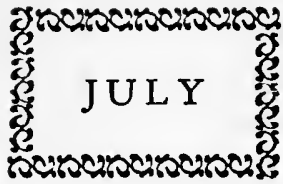

I

'WHAT think you, sister:' thus one envious fiend

To other spake upon their homeward route,

'What of the story that our wit hath glean'd

Of this mysterious lover, who can shoot

In thirty days from beardless youth to prime,

With wisdom in his face before his time,

And snowy locks upon his head to boot?'

2

'Ay,' said the other, 'true, she lied not well; And thence I gather knows no more than we:

For surely 'tis a spirit insensible

To whom she is wedded, one she cannot see.

'Tis that I fear; for if 'tis so, her child Will be a god, and she a goddess styled, Which, though I die to let it, shall not be. 
3

'Lament we thus no longer. Come, consult What may be done.' And home they came at night, Yet not to rest, but of their plots occult Sat whispering on their beds; and ere 'twas light Resolving on the deed coud not defer; But roused the sleeping house with sudden stir, And sallied forth alone to work their spite.

\section{4}

And with the noon were climb'd upon the peak, And swam down on the Zephyr as before; But now with piercing cry and doleful shriek They force their entrance through the golden door, Feigning the urgency of bitter truth; Such as deforms a friendly face with ruth, . When kindness may not hide ill tidings more.

\section{5}

Then Psyche when she heard their wailful din, And saw their countenances wan and worn With travel, vigil, and disfiguring sin, Their hair dishevel'd and their habits torn, For trembling scarce could ask what ill had hapt; And they alert with joy to see her trapt, Launch'd forth amain, and on their drift were borne. 


\section{6}

'O Psyche, happiest certainly and blest Up to this hour,' they said, 'thou surely wert, Being of thy fearful peril unpossest; Which now we would not tell but to avert. But we in solemn truth thy spouse have found To be the dragon of this mountain ground, Who holds thee here to work thy shame and hurt.

\section{7}

'As yesternight we rode upon the wind $\mathrm{He}$ issued to pursue us from the wood; We saw his back, that through the tree-tops finn'd, His fiery eyes glared from their wrinkl'd hood. Lo, now betimes the oracle, which said How to the savage beast thou shouldst be wed, Is plainly for thy safety understood.

\section{8}

'Long time hath he been known to all that dwell Upon the plain; but now his secret lair Have we discover'd, which none else coud tell :

Though many women fallen in his snare Hath he enchanted; who, tradition saith, Taste love awhile, ere to their cruel death They pass in turn upon the summits bare. 


\section{JULY}

9

'Fly with us while thou mayst: no more delay; Renounce the spells of this accursed vale. We come to save thee, but we dare not stay; Among these sightless spirits our senses quail. Fly with us, fly!' Then Psyche, for her soul Was soft and simpie, lost her self-control, And, thinking only of the horrid tale,

\section{IO}

'Dear sisters,' said she, and her sobbing speech Was broken by her terror, ' it is true That much hath hapt to stablish what ye teach; For ne'er hath it been granted me to view My husband; and, for aught I know, he may Be even that cruel dragon, which ye say Peer'd at you from the forest to pursue.

\section{II}

"Tis sure that scarcely can I win his grace To see you here; and still he mischief vows If ever I should ask to see his face, Which, coming in the dark, he ne'er allows. Therefore, if ye can help, of pity show, Since doubt I must, how I may come to know What kind of spirit it is that is my spouse.' 
Then to her cue the younger was afore : 'Hide thou a razor,' cried she, 'near thy bed; And have a lamp prepared, but whelm thereo'er Some cover, that no light be from it shed. And when securely in first sleep he lies, Look on him well, and ere he can arise, Gashing his throat, cut off his hideous head.'

\section{3}

Which both persuading, off they flew content, Divining that whate'er she was forbid Was by her lover for her safety meant, Which only coud be sure while he was hid. But Psyche, to that miserable deed Being now already in her mind agreed, Wander'd alone, and knew not what she did.

\section{I4}

Now she would trust her lover, now in turn Made question of his bidding as unjust; But thirsting curiosity to learn His secret overcame her simple trust, O'ercame her spoken troth, o'ercame her fear; And she prepared, as now the hour drew near, The mean contrivances, nor felt disgust. 


\section{JULY}

I5

She set the lamp beneath a chair, and cloked Thickly its rebel lustre from the eye : And laid the knife, to mortal keenness stroked, Within her reach, where she was wont to lie: And took her place full early; but her heart Beat fast, and stay'd her breath with sudden start, Feeling her lover's arm laid fond thereby.

\section{I6}

But when at last he slept, then she arose, All faint and tremulous : and though it be That wrong betrayeth innocence with shews Of novelty, its guilt from shame to free, Yet 'twas for shame her hand so strangely shook That held the steel, and from the cloke that took The lamp, and raised it o'er the bed to see.

\section{7}

She had some fear she might not well discern By that small flame a monster in the gloom; When lo! the air about her seem'd to burn, And bright celestial radiance fill'd the room. Too plainiy $O$ she saw, $O$ fair to see! Eros, 'twas Eros' self, her lover, he, The God of love, reveal'd in deathless bloom. 
Her fainting strength forsook her; on her knees Down by the bed she sank; the shameless knife Fell flashing, and her heart took thought to seize Its desperate haft, and end her wicked life. Yet coud she not her loving eyes withdraw From her fair sleeping lover, whom she saw Only to know she was no more his wife.

\section{I9}

O treasure of all treasures, late her own!

O loss above all losses, lost for aye !

Since there was no repentance coud atone For her dishonour, nor her fate withstay. But yet 'twas joy to have her love in sight; And, to the rapture yielding while she might, She gazed upon his body where he lay.

\section{0}

Above all mortal beauty, as was hers, She saw a rival; but if passion's heart Be rightly read by subtle questioners, It owns a wanton and a gentler part. And Psyche wonder'd, noting every sign By which the immortal God, her spouse divine, Betray'd the image of our earthly art; 
2 I

His thickly curling hair, his ruddy cheeks, And pouting lips, his soft and dimpl'd chin, The full and cushion'd eye, that idly speaks Of self-content and vanity within, The forward, froward ear, and smooth to touch His body sleek, but rounded overmuch For dignity of mind and pride akin.

\section{2}

She noted that the small irradiant wings, That from his shoulders lay along at rest, Were yet disturb'd with airy quiverings, As if some wakeful spirit his blood possest;

She feared he was awaking, but they kept Their sweet commotion still, and still he slept, And still she gazed with never-tiring zest.

And now the colour of her pride and joy Outflush'd the hue of Eros; she, so cold, To have fired the passion of the heartless boy, Whom none in heaven or earth were found to hold! Psyche, the earthborn, to be prized above The heavenly Graces by the God of love, And worshipt by his wantonness untold! 


\section{4}

Nay, for that very thing she loved him more, More than herself her sweet self's complement :

Until the sight of him again upbore

Her courage, and renew'd her vigour spent. And looking now around, she first espied Where at the bed's foot, cast in haste aside, Lay his full quiver, and his bow unbent.

One of those darts, of which she had heard so oft, She took to try if 'twas so very keen; And held its point against her finger soft So gently, that to touch it scarce was seen; Yet was she sharply prickt, and felt the fire Run through her veins; and now a strange desire Troubl'd her heart, which ne'er before had been :

\section{6}

Straight sprang she to her lover on the bed, And kisst his cheek, and was not satisfied : When, O the lamp, held ill-balanced o'erhead, One drop of burning oil spill'd from its side. On Eros' naked shoulder as he slept, Who waken'd by the sudden smart uplept Upon the floor, and all the mischief eyed. 


\section{JULY}

27

With nervous speed he seized his bow, and past

Out of the guilty chamber at a bound;

But Psyche, following his flight as fast,

Caught him, and crying threw her arms around :

Till coming to the court he rose in air;

And she, close clinging in her last despair,

Was dragg'd, and then lost hold and fell to ground.

\section{8}

Wailing she fell; but he, upon the roof Staying his feet, awhile his flight delay'd : And turning to her as he stood aloof Beside a cypress, whose profoundest shade Drank the reflections of the dreamy night In its stiff pinnacle, the nimble light Of million stars upon his body play'd :

\section{9}

'O simple-hearted Psyche,' thus he spake, And she upraised her piteous eyes and hands, 'O simple-hearted Psyche, for thy sake I dared to break my mother's stern commands; And gave thee godlike marriage in the place Of vilest shame; and, not to hurt thy grace, Spared thee my arrows, which no heart withstands. 
'But thou, for doubt I was some evil beast, Hast mock'd the warnings of my love, to spy Upon my secret, which concern'd thee least, Seeing that thy joy was never touch'd thereby. By faithless prying thou hast work'd thy fall, And, even as I foretold thee, losest all For looking on thy happiness too nigh :

\section{I}

'Which loss may be thine ample punishment. But to those fiends, by whom thou wert misled, Go tell each one in turn that $I$ have sent This message, that I love her in thy stead; And bid them by their love haste hither soon.' Whereat he fled; and Psyche in a swoon Fell back upon the marble floor as dead.

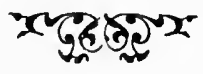




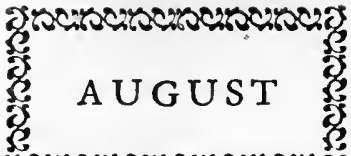 \\ 4.5\%)}

WHEN from the lowest ebbing of her blood The fluttering pulses thrill'd and swell'd again,

Her stricken heart recovering force to flood With life the sunken conduits of her brain,

Then Psyche, where she had fallen, numb and cold Arose, but scarce her quaking sense control'd, Seeing the couch where she that night had lain.

\section{2}

The level sunbeams search'd the grassy ground For diamond dewdrops. Ah! was this the place? Where was the court, her home? she look'd around And question'd with her memory for a space. There was the cypress, there the well-known wood, That wall'd the spot: 'twas here her palace stood, As surely as 'twas vanish'd without trace. 
Was all a dream?' To think that all was dreamt Were now the happier thought; but arguing o'er That dream it was, she fell from her attempt, Feeling the wifely burden that she bore. Nay, true, 'twas true. She had had all and lost; The joy, the reckless wrong, the heavy cost Were hers, the dead end now, and woe in store.

\section{4}

What to be done? Fainting and shelterless Upon the mountain it were death to bide: And harbour knew she none, where her distress Might comfort find, or love's dishonour hide; Nor felt she any dread like that of home: Yet forth she must, albeit to rove and roam An outcast o'er the country far and wide.

\section{5}

Anon she marvel'd noting from the vale A path lead downward to the plain below, Crossing the very site, whereon the pale Of all her joy had stood few hours ago; A run of mountain beasts, that keep their track Through generations, and for ages back Had trod the self-same footing to and fro. 


\section{6}

That would she try: so forth she took her way, Turning her face from the dishonour'd dell, Adown the broadening eastward lawns, which lay In gentle slant, till suddenly they fell

In sheer cliff; whence the path that went around, Clomb by the bluffs, or e'er it downward wound Beneath that precipice impassable.

\section{7}

There once she turn'd, and gazing up the slope She bid the scene of all her joy adieu; 'Ay, and farewell,' she cried, 'farewell to hope, Since there is none will rescue me anew, Who have kill'd God's perfection with a doubt.' Which said, she took the path that led about, And hid the upland pleasance from her view.

8

But soon it left her, entering 'neath the shade Of cedar old and russeted tall pine, Whose mighty tops, seen from the thorny glade, Belted the hills about; and now no sign Had she to guide her, save the slow descent. But swiftly o'er the springy floor she went, And drew the odorous air like draughts of wine. 
9

Then next she past a forest thick and dark With heavy ilexes and platanes high,

And came to long lush grass; and now coud mark By many a token that the plain was nigh. When lo! a river : to whose brink at last Being come, upon the bank her limbs she cast, And through her sad tears watch'd the stream go by.

\section{0}

And now the thought came o'er her that in death There was a cure for sorrow, that before Her eyes ran Lethe, she might take one breath Of water and be freed for evermore. Leaning to look into her tomb, thereon She saw the horror of her image wan, And up she rose at height to leap from shore.

\section{I}

When suddenly a mighty voice, that fell With fury on her ears, their sense to scare, That bounding from the tree trunks like the yell Of hundred brazen trumpets, cried 'Forbear! Forbear, fond maid, that froward step to take, For life can cure the ills that love may make; But for the harm of death is no repair.' 


\section{AUGUST}

12

Then looking up she saw. an uncouth form Perch'd on the further bank, whose parted lips Volley'd their friendly warning in a storm : A man he might have been, but for the tips Of horus appearing from his shaggy head, For o'er his matted beard his face was red, And all his shape was manlike to the hips.

\section{I3}

In forehead low, keen eye, and nostril flat He bore the human grace in mean degree, But, set beneath his body squat and fat, Legs like a goat's, and from the hairy knee The shank fell spare; and, though crosswise he put His limbs in easeful posture, for the foot The beast's divided hoof was plain to see.

\section{I4}

Him then she knew the mighty choric God, The great hill-haunting and tree-loving $P$ an; Whom Zeus had laught to see when first he trod Olympus, neither god nor beast nor man : Who every rocky peak and snowy crest Of the Aspran mountains for his own possest, And all their alps with bacchic rout o'erran : 
Whom, when his pipe he plays on loud and sweet, And o'er the fitted reeds his moist lip flees, Around in measured step with nimble feet Water-nymphs dance and Hamadryades : And all the woodland's airy folk, who shun Man's presence, to his frolic pastime run From their perennial wells and sacred trees.

\section{I6}

Now on his knee his pipe laid by, he spoke With flippant tongue, wounding unwittingly The heart he sought to cheer with jest and joke.

'And what hast thou to do with misery,' He said, 'who hast such beauty as might gain The love of Eros? Cast away thy pain, And give thy soul to mirth and jollity.

I7

' Thy mortal life is but a brittle vase, But as thee list with wine or tears to fill; For all the drops therein are Ohs and Ahs Of joy or grief according to thy will; And wouldst thou learn of me my merry way, I'd teach thee change thy lover every day, And prize the cup that thou wert fain to spill. 
18

'Nay, if thou plunge thou shalt not drown nor sink, For I will to thee o'er the stream afloat, And bear thee safe; and O I know a drink For care, that makes sweet music in the throat. Come live with me, my love ; I'll cure thy chance : For I can laugh and quaff, and pipe and dance, Swim like a fish, and caper like a goat.'

\section{9}

Speaking, his brute divinity explored The secret of her silence; and old Pan Grew kind and told her of a shallow ford Where lower down the stream o'er pebbles ran, And one might pass at ease with ankles dry: Whither she went, and crossing o'er thereby, Her lonely wanderings through the isle began.

\section{0}

But none could tell, no, nor herself had told Where food she found, or shelter through the land By day or night; until by fate control'd She came by steep ways to the southern strand, Where, sacred to the Twins and Britomart, Pent in its rocky theatre apart, A little town stood on the level sand. 
'Twas where her younger sister's husband reign'd : And Psyche to the palace gate drew near, Helplessly still by Eros' hest constrain'd, And knocking begg'd to see her sister dear; But when in state stepp'd down that haughty queen, And saw the wan face spent with tears and teen, She smiled, and said 'Psyche, what dost thou here?'

\section{2}

Then Psyche told how, having well employ'd Their means, and done their bidding not amiss, Looking on him her hand would have destroy'd, 'Twas Eros; whom in love leaning to kiss, Even as she kisst, a drop of burning oil Fall'n from the lamp had served her scheme to foil, Discovering her in vision of her bliss;

Wherewith the god stung, like a startled bird Arose in air, and she fell back in swoon; ' But ere he parted,' said she, ' he confer'd On thee the irrecoverable boon By prying lost to me: Go tell, he said, Thy sister that I love ber in thy stead, And bid ber by ber love baste bitber soon.' 


\section{4}

Which when that heart of malice heard, it took

The jealous fancy of her silly lust:

And pitilessly with triumphant look

She drank the flattery, and gave full trust;

And leaving Psyche ere she more could tell,

Ran off to bid her spouse for aye farewell,

And in his ear this ready lie she thrust:

\section{5}

' My dearest sister Psyche, she whose fate We mourn'd, hath reappear'd alive and hale, But brings sad news; my father dies : full late These tidings come, but love may yet avail; Let me be gone.' And stealing blind consent, Forth on that well-remember'd road she went, And climb'd upon the peak above the dale.

\section{6}

There on the topmost rock, where Psyche first Had by her weeping sire been left to die, She stood a moment, in her hope accurst Being happy; and the cliffs took up her cry With chuckling mockery from her tongue above, Zepbyr, sweet Zephyr, waft me to my love! When off she lept upon his wings to fly. 


\section{7}

But as a dead stone, from a height let fall, Silent and straight is gather'd by the force Of earth's vast mass upon its weight so small, In speed increasing as it nears its source Of motion-by which law all things so'er Are clutch'd and dragg'd and held-so fell she there, Like a dead stone, down in her headlong course.

\section{8}

The disregardful silence heard her strike Upon the solid crags; her dismal shriek Rang on the rocks and died out laughter-like Along the vale in hurried trebles weak; And soon upon her, from their skiey haunt Fell to their feast the great birds bald and gaunt, And gorged on her fair flesh with bloody beak.

\section{9}

But Psyche, when her sister was gone forth, Went out again her wandering way to take: And following a stream that led her north, After some days she pass'd the Corian Lake, Whereby Athena's temple stands, and he Who traverses the isle from sea to sea May by the plain his shortest journey make: 
30

Till on the northern coast arrived she came Upon a city built about a port,

The which she knew, soon as she heard the name, Was where her elder sister had her court;

To whom, as Eros had commanded her,

She now in turn became the messenger

Of vengeful punishment, that fell not short :

\section{I}

For she too hearing gan her heart exalt, Nor pity felt for Psyche's tears and moans, But, fellow'd with that other in her fault, Follow'd her to her fate upon the stones; And from the peak leaping like her below The self-same way unto the self-same woe, Lay dasht to death upon her sister's bones.

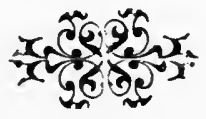




\section{EROS \& PSYCHE}

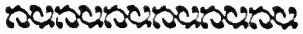

\section{THIRD QUARTER}

\section{A U T U M N

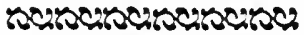

PSYCHE'S WANDERINGS

$$
\text { कृ }
$$




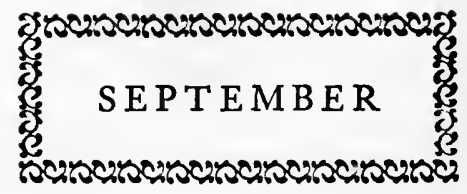

$\mathbf{I}$

$\mathrm{O}^{\mathrm{N}}$ the Hellenic board of Crete's fair isle,

Westward of Drepanon, along a reach

Which massy Cyamum for many a mile

Jutting to sea delivers from the breach

Of North and East,-returning to embay

The favour'd shore_an ancient city lay,

Aptera, which is Wingless in our speech.

\section{2}

And hence the name; that here in rocky cove,

Thence called Museion, was the trial waged

What day the Sirens with the Muses strove,

By jealous Hera in that war engaged:

Wherein the daughters of Mnemosyrè

O'ercame the chauntresses who vex'd the sea,

Nor vengeance spared them by their pride enraged. 
For those strange creatures, who with women's words

And wiles made ravenous prey of passers-by,

Were throated with the liquid pipe of birds :

Of love they sang; and none, who sail'd anigh

Through the grey hazes of the cyanine sea,

Had wit the whirlpool of that song to flee,

Nor fear'd the talon hook'd and feather'd thigh.

4

But them the singers of the gods o'ercame, And pluck'd them of their plumage, where in fright They vainly flutter'd off to hide their shame,

Upon two rocks that lie within the bight, Under the headland, barren and alone; Which, being with the scatter'd feathers strewn, Were, by the folk named Leukx, which is White.

\section{5}

Thereon about this time the snowy gull, Minion of Aphrodite, being come, Plumed himself, standing on the sea-wrack dull, That drifted from the foot of Cyamum; And 'twas his thought, that had the goddess learnt The tale of Psyche loved and Eros burnt, She ne'er so long had kept aloof and dumb. 


\section{6}

Wherefore that duteous gossip of Love's queen

Devised that he the messenger would be; And rising from the rock, he skim'd between The chasing waves - such grace have none but he ;Into the middle deep then down he dived, And rowing with his glistening wings arrived At Aphrodite's bower beneath the sea.

\section{7}

The eddies from his silver pinions swirl'd The crimson, green, and yellow floss, that grew About the caves, and at his passing curl'd Its graceful silk, and gently waved anew : Till, oaring here and there, the queen he found Stray'd fom her haunt unto a sandy ground, Dappl'd with eye-rings in the sunlight blue.

\section{8}

She, as he came upon her from above, With Hora play'd; Hora, her herald fair, That lays the soft necessity of Love On maidens' eyelids, and with tender care Marketh the hour, as in all works is fit : And happy they in love who time outwit, Fondly constrainèd in her season rare. 
9

But he with garrulous and laughing tongue Broke up his news; how Eros, fallen sick, Lay tossing on his bed, to frenzy stung By such a burn as did but barely prick : A little bleb, no bigger than a pease, Upon his shoulder 'twas, that kill'd his ease, Fever'd his heart, and made his breathing thick.

\section{Io}

'For which disaster hath he not been seen This many a day at all in any place : And thou, dear mistress,' piped he, ' hast not been Thyself amongst us now a dreary space: The pining mortals suffer from a dearth Of love; and for this sadness of the earth Thy family is darken'd with disgrace.

\section{I}

'Now on the secret paths of dale and wood, Where lovers walk'd are lovers none to find : And friends, besworn to equal brotherhood, Forget their faith, and part with words unkind : In the first moon thy honey bond is loath'd : And I could tell even of the new-betroth'd That fly o'ersea, and leave their loves behind. 
12

'Summer is over, but the merry pipe, That wont to cheer the harvesting, is mute: And in the vineyards, where the grape is ripe, No voice is heard of them that take the fruit. No workman singeth at eve nor maiden danceth : All joy is dead, and as the year advanceth The signs of woe increase on man and brute.

13

' 'Tis plain that if thy pleasure longer pause, Thy mighty rule on earth hath seen its day: The race must come to perish, and no cause But that thou sittest with thy nymphs at play, While on a Cretan hill thy truant boy Hath with his pretty mistress turn'd to toy, And less for pain than love pineth away.'

\section{4}

'Ha! Mistress!' cried she; 'Hath my beardless son Been hunting for himself his lovely game? Some young Orestiad hath his fancy won? Some Naiad? say; or is a Grace his flame? Or maybe Muse, and then 'tis Erato, The trifling wanton. Tell me, if thou know, Woman or goddess is she? and her name.' 
Then said the snowy gull, ' $\mathrm{O}$ heavenly queen, What is my knowledge, who am but a bird? Yet is she only mortal, as I ween, And namèd Psyche; if I rightly heard.'But Aphrodite's look daunted his cheer, Ascare he fled away, screaming in fear, To see what wrath his simple tale had stirr'd.

\section{6}

He flasht his pens, and sweeping widely round Tower'd to air; so swift in all his way, That whence he dived he there again was found As soon as if he had but dipt for prey : And now, or e'er he join'd his wailful flock, Once more he stood upon the Sirens' rock, And preen'd his ruffl'd quills for fresh display.

\section{I7}

But as ill tidings will their truth assure Without more witness than their fatal sense,

- So, since was nothing bitterer to endure, The injured goddess guess'd the full offence : And doubted only whether first to smite Or Psyche for her new presumptuous flight, Or Eros for his disobedience. 


\section{8}

But full of anger to her son she went, And found him in his golden chamber laid; And with him sweet Euphrosynè, attent Upon his murmur'd wants, aye as he bade Shifted the pillows with each fretful whim; But scornfully his mother look'd at him, And reckless of his pain gan thus upbraid:

\section{I9}

' $\mathrm{O}$ worthy deeds, I say, and true to blood, The crown and pledge of promise! thou that wast In estimation my perpetual bud,

Now fruiting thus untimely to my cost;

Backsliding from commandment, ay, and worse, With bliss to favour one I bade thee curse, And save the life I left with thee for lost !

20

' Thou too to burn with love, and love of her Whom I did hate; and to thy bed to take My rival, that my trusted officer Might of mine enemy my daughter make! Dost thou then think my love for thee so fond, And miserably doting, that the bond By such dishonour strainèd will not break? 
' Or that I cannot bear another son As good as thou; or, if I choose not bear, Not beg as good a lusty boy of one Of all my nymphs, -and some have boys to spare, Whom I might train, to whom thine arms made o'er Should do me kinder service than before, To smite my foes and keep my honour fair?

\section{2}

' For thou hast ever mockt me, and beguiled In amours strange my God, thy valiant sire : And having smirch'd our fame while yet a child Wilt further foul it now with earthly fire. But I-do as thou may-have vow'd to kill Thy fancied girl, whether thou love her still, Or of her silly charms already tire.

23

'Tell me but where she hides.' And Eros now, Proud in his woe, boasted his happy theft : Confessing he had loved her well, and how By her own doing she was lost and left; And homeless in such sorrow as outwent The utmost pain of other punishment, Was wandering of his love and favour reft. 


\section{4}

By which was Cypris gladden'd, not appeased, But hid her joy and spake no more her threat: And left with face like one that much displeased Hath yet betray'd that he can wrong forget.

When lo! as swiftly she came stepping down From her fair house into the heavenly town The Kronian sisters on the way she met;

\section{5}

Hera, the Wife of Zeus, her placid front Dark with the shadow of his troubl'd reign, And tall Demeter, who with men once wont, Holding the high Olympians in disdain For Persephassa's rape; which now forgiven, She had return'd unto the courts of Heaven, And 'mong the immortals liv'd at peace again :

\section{6}

Whose smile told Aphrodite that they knew The meaning of her visit; and a flush Of anger answer'd them, while hot she grew. But Hera laugh'd outright : ' Why thou dost blush! Now see we modest manners on my life! And all thy little son has got a wife Can make the crimson to thy forehead rush. 
'Didst think he, whom thou madest passion's prince, No privy dart then for himself would poise? Nay, by the cuckoo on my sceptre, since 'Twas love that made thee mother of his joys, Art thou the foremost to his favour bound; As thou shouldst be the last to think to sound The heart, and least of all thy wanton boy's.'

\section{8}

But her Demeter, on whose stalwart arm She lean'd, took up: 'If thou wilt hark to me, This Psyche,' said she, 'hath the heavenly charm, And will become immortal. And maybe To marry with a woman is as well As wed a god and live below in Hell: As 'twas my lot in child of mine to see.'

29

Which things they both said, fearing in their hearts That savage Eros, if they mockt his case, Would kill their peace with his revengeful darts, And bring them haply to a worse disgrace : But Aphrodite, saying ' Good! my dames; Behind this smoke I see the spite that flames,' Left them, and on her journey went apace. 
30

For having purposed she would hold no truce With Psyche or her son, 'twas in her mind To go forthwith unto the throne of Zeus, And beg that Hermes might be sent to find The wanderer; and secure that in such quest He would not fail, she ponder'd but how best She might inflict her vengeance long-design'd: 


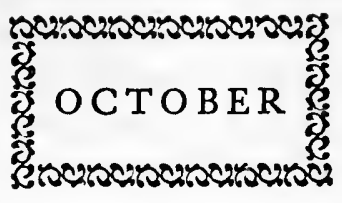

I

HEAVY meanwhile at heart, with bruisèd feet Was Psyche wandering many nights and days Upon the paths of hundred-citied Crete, And chose to step the most deserted ways; Being least unhappy when she went unseen; Since else her secret sorrow had no screen From the plain question of men's idle gaze.

2

Yet wheresoe'er she went one hope she had; Like mortal mourners, who 'gainst reason strong Hope to be unexpectedly made glad With sight of their dead friends, so much they long; So she for him, whom loss a thousandfold Endear'd and made desired; nor could she hold He would not turn and quite forgive her wrong. 
3

Wherefore her eager eyes in every place Lookt for her lover; and 'twixt hope and fear She follow'd oft afar some form of grace, In pain alike to lose or venture near. And still this thought cheer'd her fatigue, that he, Or on some hill, or by some brook or tree, But waited for her coming to appear.

\section{4}

And then for comfort many an old love-crost And doleful ditty would she gently sing, Writ by sad poets of a lover lost, Now sounding sweeter for her sorrowing: Echo, sweet Echo, watching up on bigh, Say bast thou seen to-day my love go by, Or where thou sittest by thy mossy spring?

\section{5}

Or say ye nymphs, that from the crystal rills, When ye bave batbed your limbs from morn till eve, Flying at midnight to the bare-topt bills, Beneath the stars your mazy dances weave, Say, my deserter whom ye well may know $B y$ bis small wings, bis quiver, and bis bow, Say, have ye seen my love, wbose loss I grieve? 
Till climb'd one evening on a rocky steep Above the plain of Cisamos, that lay, Robb'd of its golden harvest, in the deep Mountainous shadows of the dying day, She saw a temple, whose tall columns fair Recall'd her home; and ' $\mathrm{O}$ if thou be there, My love,' she cried, 'fly not again away.'

\section{7}

Swiftly she ran, and entering by the door She stood alone within an empty fane Of great Demeter : and, behold, the floor Was litter'd with thank-offerings of grain, With wheat and barley-sheaves together heapt In holy harvest-home of them that reapt The goddess' plenteous gifts upon the plain;

\section{8}

And on the tithe the tackle of the tithe Thrown by in such confusion, as are laid Upon the swath sickle, and hook, and scythe, When midday drives the reapers to the shade. And Psyche, since had come no priestess there To trim the temple, in her pious care Forgat herself, and lent her duteous aid. 


\section{9}

She drew the offerings from the midst aside, And piled the sheaves at every pillar's base; And sweeping therebetween a passage wide, Made clear of corn and chaff the temple space: As countrymen who bring their wheat to mart, Set out their show along the walls apart By their allotted stations, each in place;

IO

Thus she, and felt no weariness,- - such strength Hath duty to support our feeble frame,Till all was set in order, and at length Up to the threshold of the shrine she came: When lo! before her face with friendly smile, Tall as a pillar of the peristyle,

The goddess stood reveal'd, and call'd her name.

\section{I}

'Unhappy Psyche,' said she, 'know'st thou not How Aphrodite to thy hurt is sworn? And thou, thy peril and her wrath forgot, Spendest thy thought my temple to adorn. Take better heed!'--And Psyche, at the voice Even of so little comfort, gan rejoice, And at her feet pour'd out this prayer forlorn. 
' $\mathrm{O}$ Gracious giver of the golden grain, Hide me, I pray thee, from her wrath unkind; For who can pity as canst thou my pain, Who wert thyself a wanderer, vex'd in mind For loss of thy dear Corè once, whenas, Ravisht to hell by fierce Agesilas, Thou soughtest her on earth and coudst not find.

I 3

' How coud thy feet bear thee to western night, And where swart Libyans watch the sacred tree, And thrice to ford o'er Achelous bright, And all the streams of beauteous Sicily? And thrice to Enna cam'st thou, thrice, they tell, Satest athirst by Callichorus' well, Nor tookest of the spring to comfort thee.

\section{4}

' By that remember'd anguish of thine heart, Lady, have pity even on me, and show Where I may find my love; and take my part For peace, I pray, against my cruel foe: Or if thou canst not from her anger shield, Here let me lie among the sheaves conceal'd Such time till forth I may in safety go.' 


\section{5}

Demeter answer'd, 'Nay, though thou constrain My favour with thy plea, my help must still Be hidden, else I work for thee in vain To thwart my mighty sister in her will. Thou must fly hence: Yet though I not oppose, Less will I aid her; and if now I close My temple doors to thee, take it not ill.'

\section{I6}

Then Psyche's hope founder'd; as when a ship, The morrow of the gale can hardly ride The swollen seas, fetching a deeper dip At every wave, and through her gaping side And o'er her shattered bulwark ever drinks, Till plunging in the watery wild she sinks, To scoop her grave beneath the crushing tide :

\section{7}

So with each word her broken spirit drank Its doom; and overwhelm'd with deep despair She turn'd away, and coming forth she sank Silently weeping on the temple stair, In midmost night, forspent with long turmoil : But sleep, the gracious pursuivant of toil, Came swiftly down, and nursed away her care. 
And when the sun awaked her with his beams She found new hope, that still her sorrow's cure Lay with the gods, who in her morning dreams $\mathrm{Had}$ sent her comfort in a vision sure; Wherein the Cretan-born, almightiest god, Cloud-gathering Zeus himself had seem'd to nod, And bid her with good heart her woes endure.

So coming that same day unto a shrine Of Hera, she took courage and went in : And like to one that to the cell divine For favour ventures or a suit to win, She drew anigh the altar, from her face Wiping the tears, ere to the heavenly grace, As thus she pray'd, she would her prayer begin.

\section{0}

' Most honour'd Lady, who from ancient doom Wert made heaven's wife, and art on earth besought With gracious happiness of all to whom Thy holy wedlock hath my burden brought, Save me from Aphrodite's fell pursuit, And guard unto the birth Love's hapless fruit, Which she for cruel spite would bring to nought. 
' As once from her thou wert not shamed to take Her beauty's zone, thy beauty to enhance; For which again Zeus loved thee, to forsake His warlike ire in faithful dalliance; Show me what means may win my Love to me, Or how that I may come, if so may be, Within the favour of his countenance.

' If there be any place for tears or prayer, If there be need for succour in distress, Now is the very hour of all despair, Here is the heart of grief and bitterness. Motherly pity, bend thy face and grant One beam of ruth to thy poor suppliant, Nor turn me from thine altar comfortless.'

\section{3}

Even as she pray'd a cloud spread through the cell, And 'mid the wreathings of the vapour dim The goddess grew in glory visible, Like some barbaric queen in festal trim; Such the attire and ornaments she wore, When o'er the forgèd threshold of the floor Of Zeus's house she stept to visit him. 
From either ear, ring'd to its piercèd lobe A triple jewel hung, with gold enchas't ; And o'er her breasts her wide ambrosial robe With many a shining golden clasp was brac't; The flowering on its smooth embroider'd lawn Gather'd to colour where the zone was drawn In fringe of golden tassels at her waist.

\section{5}

Her curling hair with plaited braid and brail, Pendant or loop'd about her head divine, Lay hidden half beneath a golden veil, Bright as the rippling ocean in sunshine : And on the ground, flashing whene'er she stept, Beneath her feet the dazzling lightnings lept From the gold network of her sandals fine.

\section{6}

Thus Hera stood in royal guise bedeckt Before poor Psyche on the stair that knelt, Whose new-nursed hope at that display was checkt, And all her happier thoughts gan fade and melt. She saw no kindness in such haughty mien, And venturing not to look upon the queen, Bow'd down in woe to hear her sentence dealt. 
And thus the goddess spake, 'In vain thou suest, Most miserable Psyche; though my heart Be full of hate for her whose hate thou ruest, And pride and pity move me to thy part: Yet not till Zeus make known his will, coud I, Least of the blameless gods that dwell on high, Assist thee, wert thou worthier than thou art.

\section{8}

'But know if Eros love thec, that thy hopes Should rest on him; and I would bid thee go Where in his mother's house apart he mopes Grieving for loss of thee in secret woe : For should he take thee back, there is no power In earth or heaven will hurt thee from that hour, Nay, not if Zeus himself should prove thy foe.'

\section{9}

Thus saying she was gone, and Psyche now Surprised by comfort rose and went her way, Resolved in heart, and only wondering how 'Twas possible to come where Eros lay; Since that her feet, however she might roam, Could never travel to the heavenly home Of Love, beyond the bounds of mortal day : 


\section{0}

Yet must she come to him. And now 'twas proved How that to Lovers, as is told in song, Seeking the way no place is far removed; Nor is there any obstacle so strong, Nor bar so fix'd that it can hinder them : And how to reach heaven's gate by stratagem Vex'd not the venturous heart of Psyche long.

\section{I}

To face her enemy might well avail :

Wherefore to Cypris' shrine her steps she bent, Hoping the goddess in her hate might hale Her body to the skies for punishment, Whate'er to be; yet now her fiercest wrath Seem'd happiest fortune, seeing 'twas the path Whereby alone unto her love she went.

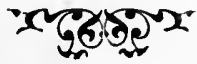




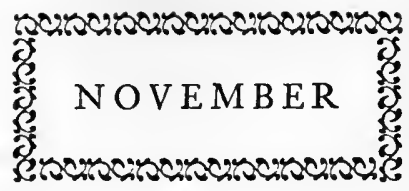

I

BUT Aphrodite to the house of Zeus

Being bound, bade beckon out her milkwhite steeds,

Four doves, that ready to her royal use

In golden cages stood and peck'd the seeds :

Best of the nimble air's high-sailing folk That wore with pride the marking of her yoke, And cooed in envy of her gentle needs.

\section{2}

These drew in turn her chariot, when in state Along the heaven with all her train she fared; And oft in journeying to the skicy gate Of Zeus's palace high their flight had dared, Which darkest vapour and thick glooms enshroud Above all else in the perpetual cloud, Wherethro' to mount again they stood prepared, 
Sleeking their feathers, by her shining car;

The same Hephæstos wrought for her, when he, Bruised in his hideous fall from heaven afar, Was nursed by Thetis, and Eurynomè, The daughter of the ever-refluent main; With whom he dwelt till he grew sound again, Down in a hollow cave beside the sea :

\section{4}

And them for kindness done was prompt to serve, Forging them brooches rich in make and mode, Earrings, and supple chains of jointed curve, And other trinkets, while he there abode : And none of gods or men knew of his home, But they two only; and the salt sea-foam To and fro past his cavern ever flow'd.

\section{5}

'Twas then he wrought this work within the cave, Emboss'd with rich design, a moonèd car; And when return'd to heaven to Venus gave, In form imagined like her crescent star; Which circling nearest earth, maketh at night To wakeful mortal men shadow and light Alone of all the stars in heaven that are. 


\section{6}

Two slender wheels it had, with fretted tires Of biting adamant, to take firm hold Of cloud or ether; and their whirling fires Threw off the air in halo where they roll'd : And either nave that round the axle turn'd A ruby was, whose steady crimson burn'd Betwixt the twin speed-mingling fans of gold.

\section{7}

Thereon the naked goddess mounting, shook The reins; whereat the doves their wings outspread,

And rising high their flight to heaven they took : And all the birds, that in those courts were bred, Of her broad eaves the nested families,

Sparrows and swallows, join'd their companies Awhile and twitter'd to her overhead.

\section{8}

But onward she with fading tracks of flame Sped swiftly, till she reacht her journey's end : And when within the house of Zeus she came, She pray'd the Sire of Heaven that he would lend Hermes, the Argus-slayer, for her hest; And he being granted her at her request, She went forthwith to seek him and to send. 
9

Who happ'd within the palace then to wait Upon the almighty pleasure; and her tale Was quickly told, and he made answer straight That he would find the truant without fail; Asking the goddess by what signs her slave Might best be known, and what the price she gave For capture, or admitted for the bail.

\section{IO}

All which he took his silver stile to write In letters large upon a waxèd board; Her age and name, her colour, face and height, Her home, and parentage, and the reward : And then read o'er as 'twas to be proclaim'd. And she took oath to give the price she named, Without demur, when Psyche was restored.

\section{I}

Then on his head he closely set his cap With earèd wings erect, and o'er his knee He cross'd each foot in turn to prove the strap That bound his wingèd sandals, and shook free His chlamys, and gat up, and in his hand Taking his fair white-ribbon'd herald's wand, Lept forth on air, accoutred cap-a-pè. 
I 2

And piloting along the mid-day sky,

Held southward, till the narrow map of Crete

Lay like a fleck in azure 'neath his eye;

When down he came, and as an eagle fleet

Drops in some combe, then checks his headlong stoop

With wide-flung wing, wheeling in level swoop

To strike the bleating quarry with his feet,

\section{3}

Thus he alighted; and in every town

In all the isle before the close of day

Had cried the message, which he carried down,

Of Psyche, Aphrodite's runaway;

That whosoever found the same and caught,

And by such time unto her temple brought,

To him the goddess would this guerdon pay:

\section{I4}

SIX HONIED KISSES FROM HER ROSY MOUTH Would Cytherea give, and one beside

TO QUENCH AT HEART FOR AYE LOVE'S MORTAL DROUTH :

But UNTO HIM THAT HID HER, WOE BETIDE!

Which now was on all tongues, and Psyche's name Herself o'erheard, or ever nigh she came To Aphrodite's temple where she hied. 


\section{5}

When since she found her way to heaven was safe, She only wisht to make it soon and sure; Nor fear'd to meet the goddess in her chafe, So she her self-surrender might secure, And not be given of other for the price; Nor was there need of any artifice Her once resplendent beauty to obscure.

\section{6}

For now so changed she was by heavy woe, That for the little likeness that she bore To her description she was fear'd to go Within the fane; and when she stood before The priestess, scarce coud she with oath persuade That she was Psyche, the renownèd maid, Whom men had left the temple to adore.

\section{7}

But when to Hermes she was shown and given, He took no doubt, but eager to be quit, . And proud of speed, return'd with her to heaven, And left her with the proclamation writ, Hung at her neck, the board with letters large, At Aphrodite's gate with those in charge; And up whence first he came made haste to fit. 
But hapless Psyche fell, for so it chanced, To moody Synethea's care, the one Of Aphrodite's train whom she advanced To try the work abandon'd by her son. Who by perpetual presence made ill end Of good or bad; though she coud both amend, And merit praise for work by her begun.

\section{I9}

But she to better thought her heart had shut, And proved she had a spite beyond compare: Nor coud the keenest taunts her anger glut, Which she when sour'd was never wont to spare: And now she mock'd at Psyche's shame and grief, As only she might do, and to her chief Along the courtyard dragg'd her by the hair.

\section{0}

Nor now was Aphrodite kinder grown : Having her hated rival in her power, She laught for joy, and in triumphant tone Bade her a merry welcome to her bower : 6'Tis fit indeed daughters-in-law should wait Upon their mothers; but thou comest late, Psyche; I lookt for thee before this hour. 
'And yet,' thus gave she rein to jeer and gibe,

'Forgive me if I held thee negligent,

Or if accustom'd vanity ascribe

An honour to myself that was not meant.

Thy lover is it, who so dearly prized

The pretty soul, then left her and despised?

To him more like thy heavenward steps were bent :

\section{2}

'Nor without reason: Zeus, I tell thee, swoon'd To hear the story of the drop of oil, The revelation and the ghastly wound : My merriment is but my fear's recoil. But if my son was unkind, thou shalt see How kind a goddess can his mother be To bring thy tainted honour clear of soil.'

23

And so, to match her promise with her mirth, Two of her ministers she call'd in ken, That work the melancholy of the earth; MERIMNA that with care perplexes, when The hearts of mortals have the gods forgot, And LYPe, that her sorrow spares them not, When mortals have forgot their fellow men. 
24

These, like twin sharks that in a fair ship's wake Swim constant, showing 'bove the water blue Their shearing fins, and hasty ravin make Of overthrow or offal, so these two On Aphrodite's passing follow hard; And now she offer'd to their glut's regard Sweet Psyche, with command their wont to do.

\section{5}

But in what secret chamber their foul task These soul-tormentors plied, or what their skill, Pity of tender nature may not ask, Nor poet stain his rhyme with such an ill. But they at last themselves turn'd from their rack, Weary of cruelty, and led her back, Saying that further torture were to kill.

\section{6}

Then when the goddess saw her, more she mockt, 'Art thou the woman of the earth,' she said, 'That hast in sorceries mine Eros lockt, And stood thyself for worship in my stead? Looking that I should pity thee, or care For what illicit offspring thou mayst bear; Or let thee to that god my son be wed? 
'I know thy trick; and thou art one of them Who steal love's favour in the gentle way, Wearing submission for a diadem, Patience and suffering for thy rich array: Thou wilt be modest, kind, implicit, so To rest thy wily spirit out of show That it may leap the livelier into play :

\section{8}

'Devout at doing nothing, if so be The grace become thee well; but active yet Above all others be there none to see Thy business, and thine eager face asweat. Lo! I will prove thy talent : thou mayst live, And all that thou desirest will I give, If thou perform the task which I shall set.'

\section{9}

She took her then aside, and bade her heed A heap of grains piled high upon the floor, Millet and mustard, hemp and poppy seed, And fern-bloom's undistinguishable spore, All kinds of pulse, of grasses, and of spice, Clover and linseed, rape, and corn, and rice, Dodder, and sesame, and many more. 
'Sort me these seeds' she said; ' it now is night, I will return at morning; if I find

That thou hast separated all aright,

Each grain from other grain after its kind, And set them in unmingl'd heaps apart,

Then shall thy wish be granted to thine heart.' Whereat she turn'd, and closed the door behind. 


\title{
EROS \& PSYCHE
}

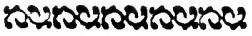 \\ FOURTH QUARTER \\ W I N T E R \\ schesscisis \\ PSYCHE'S TRIALS AND RECEPTION \\ INTO HEAVEN

$$
\text { कृष }
$$




$$
\text { - }
$$




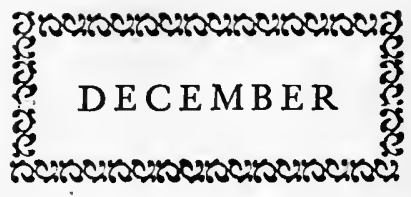

I

A SINGLE lamp there stood beside the heap, And shed thereon its mocking golden light;

Such as might tempt the weary eye to sleep Rather than prick the nerve of taskèd sight. Yet Psyche, not to fail for lack of zeal, -With good will sat her down to her ordeal, Sorting the larger seeds as best she might.

2

When lo! upon the wall, a shadow past Of doubtful shape, across the chamber dim Moving with speed : and seeing nought that cast The shade, she bent her down the flame to trim; And there the beast itself, a little ant, Climb'd up in compass of the lustre scant, Upon the bowl of oil ran round the rim. 
Smiling to see the creature of her fear So dwarf'd by truth, she watcht him where he crept, For mere distraction telling in his ear What straits she then was in, and telling wept. Whereat he stood and trim'd his horns; but ere Her tale was done resumed his manner scare, Ran down, and on his way in darkness kept.

\section{4}

But she intent drew forth with dextrous hand The larger seeds, or push'd the smaller back, Or light from heavy with her breathing fan'd. When suddenly she saw the floor grow black, And troops of ants, flowing in noiseless train, Moved to the hill of sceds, as o'er a plain Armies approach a city for attack;

\section{5}

And gathering on the grain, began to strive With grappling horns: and each from out the heap His burden drew, and all their motion live Struggled and slid upon the surface steep. And Psyche wonder'd, watching them, to find The creatures separated kind from kind : Till dizzied with the sight she fell asleep. 
6

And when she woke 'twas with the morning sound Of Aphrodite's anger at the door, Whom high amaze stay'd backward, as she found Her foe asleep with all her trouble o'er : And round the room beheld, in order due, The piles arranged distinct and sorted true, Grain with grain, seed with seed, and spore with spore.

\section{7}

She fiercely cried ' Thou shalt not thus escape; For to this marvel dar'st thou not pretend. There is but one that coud this order shape, Demeter,--but I knew her not thy friend. Therefore another trial will I set, In which she cannot aid thee nor abet, But thou thyself must bring it fair to end.'

8

Thereon she sped her to the bounds of Thrace, And set her by a river deep and wide, And said ' $T o$ east beyond this stream, a race Of golden-fleecèd sheep at pasture bide. Go seek them out; and this thy task, to pull. But one lock for me of their precious wool, And give it in my hands at eventide : 
'This do and thou shalt have thy heart's desire.' Which said, she fled and left her by the stream: And Psyche then, with courage still entire Had plunged therein; but now of great esteem Her life she rated, while it lent a spell Wherein she yet might hope to quit her well, And in one winning all her woes redeem.

\section{Io}

There as she stood in doubt, a fluting voice Rose from the flood, ' Psyche, be not afraid To hear a reed give tongue, for 'twas of choice That I from mortal flesh a plant was made. My name is Syrinx; once from mighty Pan Into the drowning river as I ran, A fearful prayer my steps for ever stay'd.

\section{I}

' But by that change in many climes I live; And Pan, my lover, who to me alone Is true and does me honour, I forgiveNor if I speak in sorrow is't my own : Rather for thee my voice I now uplift To warn thee plunge not in the river swift, Nor seek the golden sheep to men unknown. 
I 2

'If thou should cross the stream, which may not be Thou coudst not climb upon the hanging rocks, Nor ever, as the goddess bade thee, see The pasture of the yellow-fleecèd flocks : Or if thou coud, their herded horns would gore And slay thee on the crags, or thrust thee o'er Ere thou coudst rob them of their golden locks.

\section{3}

'The goddess means thy death. But I can show How thy obedience yet may thwart her will. At noon the golden flocks descend below, Leaving the scented herbage of the hill, And where the shelving banks to shallows fall, Drink at the rippling water one and all, Nor back return till they have drawn their fill.

\section{I4}

'I will command a thornbush, that it stoop Over some ram that steppeth by in peace, And him in all its prickles firmly coop, Making thee seizure of his golden fleece; So without peril of his angry horns Shalt thou be quit: for he upon the thorns Must leave his ransom ere he win release.' 
Then Psyche thankt her for her kind befriending, And hid among the rushes looking east; And when noon came she saw the flock descending Out of the hills; and lo! one golden beast Caught in a thornbush; and the mighty brute Struggl'd and tore it from its twisted root Into the stream, or e'er he was releas't.

\section{6}

And when they water'd were and gone, the breeze Floated the freighted thorn where Psyche lay: Whence she unhook'd the golden wool at ease, And back to heaven for passage swift gan pray. And Hermes, who was sent to be her guide Ifso she lived, came down at eventide, And bore her thither ere the close of day.

17

But when the goddess saw the locks of gold Held to her hands, her heart with wrath o'erran : 'Most desperate thou, and by abetting bold, That dost outwit me, prove thee as I can. Yet this work is not thine: there is but one Of all the gods who coud the thing have done. Hast thou a friend too in the lusty Pan? 
18

'I'll give thee trial where he cannot aid.' Which said, she led her to a torrid land, Level and black, but not with flood or shade, For nothing coud the mighty heat withstand, Which aye from morn till eve the naked sun Pour'd on that plain, where never foot had run, Nor any herb sprung on its molten sand.

\section{9}

Far off a gloomy mountain rose alone : And Aphrodite, thither pointing, said ' There lies thy task. Out of the topmost stone Of yonder hill upwells a fountain head. Take thou this goblet; brimming must thou bring Its cup with water from that sacred spring, If ever to my son thou wouldst be wed.'

20

Saying, she gave into her hands a bowl Cut of one crystal, open, broad and fair; And bade her at all hazard keep it whole, For heaven held nought beside so fine or rare. Then was she gone; and Psyche on the plain Now doubted if she ever should regain The love of Eros, strove she howsoe'er. 
Yet as a helmsman, at the word to tack, Swiftly without a thought puts down his helm, So Psyche turn'd to tread that desert black, Since was no fear that coud her heart o'erwhelm; Nor knew she that she went the fount to seek Of cold Cocytus, springing to the peak, Secretly from his source in Pluto's realm.

\section{2}

All night and day she journey'd, and at last Come to the rock gazed up in vain around : Nothing she saw but precipices vast O'er ruined scarps, with rugged ridges crown'd : And creeping to a cleft to rest in shade, Or e'er the desperate venture she assay'd, She fell asleep upon the stony ground.

\section{3}

A dream came to her, thus : she stood alone Within her palace in the high ravine; Where nought but shewas changed, but she to stone. Worshippers throng'd the court, and still were seen Folk flying from the peak, who, ever more Flying and flying, lighted on the floor, Hail! cried they, wife of Eros, adorèd queen! 


\section{4}

A hurtling of the battl'd air disturb'd

Her sunken sense, and waked her eyes to meet The kingly bird of Zeus, himself that curb'd His swooping course, alighting at her feet; With motion gentle, his far-darting eye In kindness dim'd upon her, he drew nigh, And thus in words unveil'd her foe's deceit :

\section{5}

'In vain, poor Psyche, hast thou hither striven Across the fiery plain toiling so well; Cruelly to destruction art thou driven By her, whose hate thou canst not quit nor quell. No mortal foot may scale this horrid mount, And those black waters of its topmost fount Are guarded by the hornèd snakes of hell.

\section{6}

' Its little rill is an upleaping jet

Of co'd Cocytus, which for ever licks Earth's base, and when with Acheron 'tis met,

Its waters with that other cannot mix, Which holds the elemental air dissolved; But with it in its ceaseless course revolved Issues unmingl'd in the lake of Styx. 
'The souls of murderers, in guise of fish, Scream as they swim therein and wail for cold, Their times of woe determined by the wish Of them they murder'd on the earth of old : Whom each five years they see, whene'er they make Their passage to the Acherusian lake, And there release may win from pains condoled.

\section{8}

'For if the pitying ear of them they slew Be haply piercèd by their voices spare, Then are they freed from pain; as are some few; But, for the most, again they forward fare To Tartarus obscene, and outcast thence Are hurried back into the cold intense, And with new company their torments share.

\section{9}

' Its biting lymph may not be touch'd of man Or god, unless the Fates have so ordain'd; Nor coud I in thy favour break the ban, Nor pass the dragons that thereby are chain'd, Didst thou not bear the sacred cup of Zeus; Which, for thy peril lent, shall turn to use; And truly do the service which it feign'd.' 
30

Thus as he spake, his talons made he ring Around the crystal bowl, and soaring high

Descended as from heaven upon the spring:

Nor dared the hornèd snakes of hell deny

The minister of Zeus, that bore his cup,

To fill it with their trusted water up,

Thence to the King of heaven therewith to fly.

\section{$3 \mathrm{I}$}

But he to Psyche bent his gracious speed, And bidding her to mount his feather'd back Bore her aloft as once young Ganymede; Nor ever made his steady flight to slack, Ere that he set her down beside her goal, And gave into her hands the crystal bowl Unspill'd, o'erbrimming with the water black.

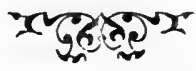




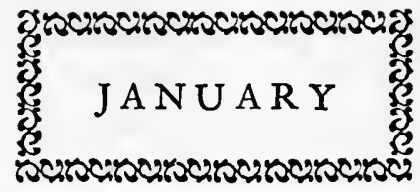

I

BUT Eros now recover'd from his hurt,

Felt other pangs; for who would not relent Weighing the small crime and unmatch'd desert Of Psyche with her cruel punishment?

And shamed he grew to be so near allied To her, who by her taunts awoke his pride, As his compassion by her spite unspent.

2

Which Aphrodite seeing, wax'd more firm That he should never meet with Psyche more; And had in thought already set the term To their communion with that trial sore, Which sent her forth upon a quest accurst, And not to be accomplisht, that of thirst She there might perish on hell's torrid shore. 
And now it chanced that she had called her son Into her presence-chamber, to unfold Psyche's destruction, that her fate might stun What love remained by duty uncontrol'd; And he to hide his tears' rebellious storm Was fled; when in his place another form Rose 'neath the golden lintel; and behold

\section{4}

Psyche herself, in slow and balanced strain, Poising the crystal bowl with fearful heed, Her eyes at watch upon the steadied plane, And whole soul gather'd in the single deed. Onward she came, and stooping to the floor Set down the cup unspill'd and brimming o'er At Aphrodite's feet, and rose up freed.

\section{5}

Surprise o'ercame the goddess, and she too Stood like a statue, but with passion pale: Till, when her victim nothing spake, she threw Some kindness in her voice, and bade her hail; But in the smiling judge 'twas plain to seeSaying 'What water bringst thou here to me?'That justice over hate should not prevail. 
Then Psyche said ' This is the biting flood Of black Cocytus, silver'd with the gleam Of souls, that guilty of another's blood Are pent therein, and as they swim they scream. The hornèd snakes of hell, upon the mount Enchain'd, for ever guard the livid fount : And but the Fates can grant to touch the stream.'

\section{7}

'Wherefore,' the goddess cried, ' 'tis plain that none But one I wot of coud this thing have wrought. That which another doth may well be done, Nor thou the nearer to my promise brought. Thou buildest on a hope to be destroy'd, If thou accept conditions, and avoid Thy parcel, nor thyself accomplish aught.

8

'Was it not kindness in me, being averse To all thy wish, to yield me thus to grant Thy heart's desire, -and nothing loathe I worse,If thou wouldst only work as well as want? See, now I will not yet be all denial, But offer thee one last determining trial; And let it be a mutual covenant: 
9

'This box,' and in her hands she took a pyx Square-cut, of dark obsidian's rarest green, 'Take; and therewith beyond Tartarean Styx Go thou, and entering Hades' house obscene, Say to Persephonè, If 'tis thy will To shew me so much favour, pritbee fill This little vase with beauty for Love's queen.

10

'Sbe begs but what shall well o'erlast a day;

For of ber own was much of late outspent

In nursing of ber son, in bed who lay

Wounded by me, who for the gift am sent.

Then bring me what she gives, and with all speed;

For truth to say I stand, thou seest, in need

Of some such charm in my disparagement.

\section{I}

'If thou return to me with that acquist,

Having thyself the journey made, I swear That day to give thee whatsoe'er thou list, An be it my son. Now, Psyche, wilt thou dare?' And Psyche said 'If this thou truly mean, I will go down to Tartarus obscene, And beg of Hades' queen thy beauty there. 
'Show me the way.' But Aphrodite said, 'That mayst thou find. Yet I will place thee whence A way there is : mortals have on it sped; Ay, and return'd thereby : so let us hence.' Then swift to earth her willing prey she bore, And left her on the wide Laconian shore, Alone, at midnight, in the darkness dense.

13

'Twas winter; and as shivering Psyche sat Waiting for morn, she question'd in her mind What place the goddess meant, arrived whereat She might descend to hell, or how should find The way which Gods to living men deny. 'No Orpheus, nay, nor Hercules am I,' Said she, 'to loosen where the great Gods bind.'

\section{I4}

And when at length the long-delaying dawn Broke on the peaks of huge Taÿgetus, And Psyche through the skirts of dark withdrawn Look'd on that promontory mountainous, And saw high-crested Taleton in snow, Her heart sank, and she wept with head bent low The malice of her foe dispiteous. 


\section{JANUARY}

15

And seeing near at hand an ancient tower,

Deserted now, but once a hold of men,

She came thereto, and, though 'twas all her power,

Mounted its steep unbroken stair again.

'Surely,' she said, for now a second time

She thought to die-' this little height I climb

Will prove my shortest road to Pluto's den.

16

'Hence must I come to Tartarus; once there Turn as I may,' and straight to death had sprung;

When in the mossy tower the imprison'd air

Was shaken, and the hoary stones gave tongue,

'Stand firm! stand firm!' that rugged voice outcried;

' Of such as choose despondency for guide

Hast thou not heard what bitterest fate is sung?

17

'Hearken; for I the road and means can teach How thou mayst come to hell and yet escape. And first must thou, that upper gate to reach, Along these seagirt hills thy journey shape, To where the land in sea dips furthest South At Tænarus and Hades' earthly mouth, Hard by Poseidon's temple at the cape. 
' Thereby may one descend: but they that make That passage down must go provided well. So take in either hand a honey-cake Of pearlèd barley mix'd with hydromel; And in thy mouth two doits, first having bound The pyx beneath thy robe enwrap'd around : Thus set thou forth; and mark what more I tell.

\section{I9}

'When thou hast gone alone some half thy road Thou wilt o'ertake a lame outwearied ass; And one that beats him, tottering 'neath his load Of loosely bundl'd wood, will cry Alas; Help me, kind friend, my faggots to adjust! But thou that silly cripple's words mistrust; 'Tis planted for thy death. Note it and pass.

' And when thy road the Stygian river joins, Where woolly Charon ferries o'er the dead, He will demand his fare : one of thy coins Force with thy tongue between thy teeth, thy head Offering instead of hand to give the doit. His fingers in this custom are adroit, And thine must not set down the barleybread. 
' Then in his crazy bark as, ferrying o'er The stream, thou sittest, one that seems to float Rather than swim, midway 'twixt shore and shore, Will stretch his fleshless hand upon the boat, And beg thee of thy pity take him in. Shut thy soft ear unto his clamour thin, Nor for a phantom deed thyself devote.

\section{2}

'Next, on the further bank when thou art stept, Three wizen'd women weaving at the woof Will stop, and pray thee in their art adept To free their tangl'd threads. Hold thou aloof; For this and other traps thy foe hath plan'd To make thee drop the cakes out of thy hand, Putting thy prudence to perpetual proof.

\section{3}

' For by one cake thou comest into Hell, And by one cake departest; since the hound That guards the gate is ever pleasèd. well To taste man's meal, or sweeten'd grain unground. Cast him a cake; for that thou mayst go free Even to the mansion of Persephonè, Withouten stay or peril, safe and sound. 
24

'She will receive thee kindly; thou decline Her courtesies, and make the floor thy seat; Refusing what is offer'd, food or wine; Save only beg a crust of bread to eat. Then tell thy mission, and her present take; Which when thou hast, set forth with pyx and cake, One in each hand, while yet thou mayst retreat.

25

'Giving thy second cake to Cerberus, The coin to Charon, and that way whereby Thou camest following, thou comest thus To see again the starry choir on high. But guard thou well the pyx, nor once uplift The lid to look on Persephassa's gift; Else 'tis in vain I bid thee now not die.'

26

Then Psyche thank'd the tower, and stoopt her mouth

To kiss the stones upon his rampart hoary; And coming down his stair went hasting south, Along the steep Trenarian promontory; And found the cave and temple by the cape, And took the cakes and coins, and made escape Beneath the earth, according to his story. 
27

And overtook the ass, but lent no aid; And offer'd Charon with her teeth his fee; And pass'd the floating ghost, in vain who pray'd; And turned her back upon the weavers three: And threw the honey-cake to that hell-hound Three-headed Cerberus; and safe and sound, Came to the mansion of Persephonè.

\section{8}

Kindly received, she courtesy declined; Sat on the ground; ate not, save where she lay, A crust of bread; reveal'd the goddess' mind; The gift took; and return'd upon her way: Gave Cerberus his cake, Charon his fare, And saw through Hell's mouth to the purple air And one by one the keen stars melt in day.

\section{9}

Awhile from so long journeying in the shades Resting at Tænarus she came to know How, up the eastern coast some forty stades, There stood a temple of her goddess foe. There would she make her offering, there reclaim The prize, which now 'twas happiness to name, The joy that should redeem all passèd woe. 


\section{0}

And wending by the sunny shore at noon, She with her pyx, and wondering what it hid, Of what kind, what the fashion of the boon Coud be, that she to look on was forbid,Alas for Innocence so hard to teach !At fancy's prick she sat her on the beach, And to content desire lifted the lid.

\section{1}

She saw within nothing: But o'er her sight That looked on nothing gan a darkness creep. A cloudy poison, mix'd of Stygian night, Rapt her to deadly and infernal sleep. Backward she fell, like one when all is o'er, And lay outstretch'd, as lies upon the shore A drown'd corpse cast up by the murmuring deep.

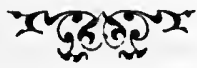




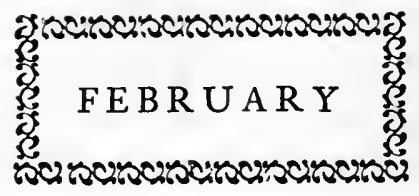

$\mathbf{I}$

WHILE Eros in his chamber hid his tears, Mourning the loss of Psyche and her fate,

The rumour of her safety reacht his ears And how she came to Aphrodite's gate: Whereat with hope return'd his hardihood, And secretly he purposed while he coud Himself to save her from the goddess' hate.

2

Then learning what he might and guessing more,

His ready wit came soon to understand The journey to the far Laconian shore; Whither to fly and seek his love he plan'd : And making good escape in dark of night, Ere the sun crost his true meridian flight He by Teuthronè struck the southern strand. 
There as it chanct he found that snowy bird Of Crete, that late made mischief with his queen, And now along the cliffs with wings unstir'd Sail'd, and that morn had cross'd the sea between : Whom as he past he hail'd, and question'd thus, 'O snowy gull, if thou from Tænarus Be come, say, hast thou there my Psyche seen ?'

\section{4}

The gull replied ' Thy Psyche have I seen; Walking beside the sea she joy'th to bear A pyx of dark obsidian's rarest green, Wherein she gazeth on her features fair. She is not hence by now six miles at most.' Then Eros bade him speed, and down the coast Held on his passage through the buoyant air.

\section{5}

With eager eye he search'd the salty marge Boding all mischief from his mother's glee; And wondering of her wiles, and what the charge Shut in the dark obsidian pyx might be. And lo! at last, outstretch'd beside the rocks, Psyche as lifeless; and the open box Laid with the weedy refuse of the sea. 
6

He guess'd all, flew down, and beside her knelt, With both his hands stroking her temples wan; And for the poison with his fingers felt, And drew it gently from her; and anon She slowly from those Stygian fumes was freed; Which he with magic handling and good heed Replaced in pyx, and shut the lid thereon.

\section{7}

'O Psyche,' thus, and kissing her he cried,

' O simple-hearted Psyche, once again Hast thou thy foolish longing gratified, A second time hath prying been thy bane. But lo! I, love, am come, for I am thine: Nor ever more shall any fate malign, Or spite of goddess smite our love in twain.

\section{8}

'Let now that I have saved thee twice outweigh The once that I deserted thee: and thou Hast much obey'd for once to disobey, And wilt no more my bidding disallow. Take up thy pyx; to Aphrodite go, And claim the promise of thy mighty foe; Maybe that she will grant it to thee now. 
'If she should yet refuse, despair not yet!'

Then Psyche, when she felt his arms restore Their old embrace, and as their bodies met, Knew the great joy that grief is pardon'd for ; And how it doth first ecstasy excel, When love well-known, long-lost, and mournèd well

In long days of no hope, comes home once more.

\section{Io}

But Eros leaping up with purpose keen Into the air, as only love can fly, Bore her to heaven, and setting her unseen At Aphrodite's golden gate, - whereby They came as night was close on twilight dim,There left, and bidding her say nought of him, Went onward to the house of Zeus most high.

\section{I}

Where winning audience of the heavenly sire, Who well disposed to him was used to be, He told the story of his strong desire; And boldly begg'd that Zeus would grant his plea, That he might have sweet Psyche for his wife, And she be dower'd with immortal life, Since she was worthy, by his firm decree. 
I 2

And great Zeus smiled; and at the smile of Zeus All heaven was glad, and on the earth below Was calm and peace awhile and sorrow's truce: The sun shone forth and smote the winter snow, The flowërs sprang, the birds gan sing and pair, And mortals, as they drew the brighten'd air, Marvel'd, and quite forgot their common woe.

13

Yet gave the Thunderer not his full consent Without some words : ' At length is come the day,' Thus spake he, 'when for all thy youth misspent, Thy mischief-making and thy wanton play Thou art upgrown to taste the sweet and sour: Good shall it work upon thee : from this hour Look we for better things. And this I say,

\section{4}

' That since thy birth, which all we took for bliss, Thou hast but mock'd us; and no less on me Hast brought disfavour and contempt, ywiss, Than others that have had to do with thee : Till only such as vow'd themselves aloof From thee and thine were held in good aproof; And few there were, who thus of shame went free. 
' That punishment is shapen as reward Is like thy fortune : but our good estate We honour, while we sit to be adored: And thus 'twas written in the book of Fate. Not for thy pleasure, but the general weal Grant I the grace for which thou here dost kneel; And that which I determine shall not wait.'

So wingèd Hermes through the heaven he sped, To warn the high celestials to his hall, Where they should Psyche see with Eros wed, And keep the day with feast ambrosial. And Hermes, flying through the skiey ways Of high Olympus, spread sweet Psyche's praise, And bade the mighty gods obey his call.

17

Then all the Kronian gods and goddesses Assembl'd at his cry, -and now 'twas known Why Zeus had smiled,-the lesser majesties Attending them before his royal throne. Athena, mistress good of them that know, Came, and Apollo, warder off of woe, Who had to Psyche's sire her fate foreshown; 
18

Demeter, giver of the golden corn,

Fair Hebe, honour'd at her Attic shrine,

And Artemis with hunting spear and horn,

And Dionysos, planter of the vine,

With old Poseidon from the barren sea,

And Leto, and the lame Hephrstos, he

Himself who built those halls with skill divine.

19

And ruddy Pan with many a quip and quirk Air'd 'mong those lofty gods his mirth illbred, Bearing a mighty bowl of cretan work: Stern Arês, with his crisp hair helmeted,

Came, and retirèd Hestia, and the god Hermes, with wingèd cap and ribbon'd rod, By whom the company was heralded.

\section{0}

And Hera sat by Zeus, and all around The Muses, that of learning make their choice; Who, when Apollo struck his strings to sound, Sang in alternate music with sweet voice: And righteous Themis, and the Graces three Ushering the anger'd Aphrodite; she Alone of all were there might not rejoice. 
But ere they sat to feast, Zeus bade them fill The cup ambrosial of immortal life, And said 'If Psyche drink, -and 'tis my will,There is an end of this unhappy strife. Nor can the goddess, whose mislike had birth From too great honour paid the bride on earth, Forbid her any more for Eros' wife.'

Then Aphrodite said 'So let it 'be.' And Psyche was brought in, with such a flush Of joy upon her face, as there to see Was fairer to love's eye than beauty's blush. And then she drank the eternal wine, whose draught Can Terror cease : which flesh hath never quafft, Nor doth it flow from grape that mortals crush.

\section{3}

And next stood Eros forth, and took her hand, And kisst her happy face before them all : And Zeus proclaim'd them married, and outban'd From heaven whoever should that word miscall. And then all sat to feast, and one by one Pledged Psyche ere they drank and cried Well done! And merry laughter rang throughout the hall. 


\section{4}

So thus was Eros unto Psyche wed, The heavenly bridegroom to his earthly bride, Who won his love, in simple maidenhead: And by her love herself she glorified, And him from wanton wildness disinclined; Since in his love for her he came to find A joy unknown through all Olympus wide.

\section{5}

And Psyche for her fall was quite forgiven, Since 'gainst herself when tempted to rebel, By others' malice on her ruin driven, Only of sweet simplicity she fell :Wherein who fall may fall unto the skies;And being foolish she was yet most wise, And took her trials patiently and well.

\section{6}

And Aphrodite since her full defeat Is kinder and less jealous than before, And smiling on them both, calls Psyche sweet; But thinks her son less manly than of yore : Though still she holds his arm of some renown, When he goes smiting mortals up and down, Piercing their marrow with his weapons sore. 
So now in steadfast love and happy state They hold for aye their mansion in the sky, And send down heavenly peace on those who mate, In virgin love, to find their joy thereby : Whom gently Eros shooteth, and apart Keepeth for them from all his sheaf that dart Which Psyche in his chamber pickt to try.

\section{8}

Now in that same month Psyche bare a child, Who straight in heaven was namèd Hedonè In mortal tongues by other letters styled; Whom all to love, however named, agree: Whom in our noble English JOY we call, And honour them among us most of all, Whose happy children are as fair as she.

29

ENVOY

IT IS MY PRAYER THAT SHE MAY SMILE ON ALL WHO READ MY TALE AS SHE HATH SMILED ON ME. 


THE GROWTH

\author{
OF \\ L OVE
}

\%ా 



\section{THE GROW TH \\ OF LOVE}

\section{(1)}

\section{I}

THEY that in play can do the thing they would, Having an instinct throned in reason's place, -And every perfect action hath the grace Of indolence or thoughtless hardihoodThese are the best : yet be there workmen good Who lose in earnestness control of face,

Or reckon means, and rapt in effort base Reach to their end by steps well understood.

Me whom thou sawest of late strive with the pains Of one who spends his strength to rule his nerve, -Even as a painter breathlessly who strains His scarcely moving hand lest it should swerveBehold me, now that I have cast my chains, Master of the art which for thy sake I serve. 


\section{2}

For thou art mine : and now I am ashamed To have usèd means to win so pure acquist, And of my trembling fear that might have misst Thro' very care the gold at which I aim'd; And am as happy but to hear thee named, As are those gentle souls by angels kisst In pictures seen leaving their marble cist To go before the throne of grace unblamed.

Nor surer am I water hath the skill To quench my thirst, or that my strength is freed In delicate ordination as I will, Than that to be myself is all I need For thee to be most mine: so I stand still, And save to taste my joy no more take heed. 


\section{3}

THE whole world now is but the minister

Of thee to me: I see no other scheme

But universal love, from timeless dream

Waking to thee his joy's interpreter.

I walk around and in the fields confer

Of love at large with tree and flower and stream,

And list the lark descant upon my theme,

Heaven's musical accepted worshipper.

Thy smile outfaceth ill : and that old feud 'Twixt things and me is quash'd in our new truce; And nature now dearly with thee endued No more in shame ponders her old excuse, But quite forgets her frowns and antics rude, So kindly hath she grown to her new use. 


\section{4}

THE very names of things belov'd are dear, And sounds will gather beauty from their sense, As many a face thro' love's long residence Groweth to fair instead of plain and sere: But when I say thy name it hath no peer, And I suppose fortune determined thence Her dower, that such beauty's excellence Should have a perfect title for the ear.

Thus may I think the adopting Muses chose Their sons by name, knowing none would be heard Or writ so oft in all the world as those,Dan Chaucer, mighty Shakespeare, then for third The classic Milton, and to us arose Shelley with liquid music in the word. 


\section{s}

THE poets were good teachers, for they taught Earth had this joy; but that 'twould ever be That fortune should be perfected in me, My heart of hope dared not engage the thought. So I stood low, and now but to be caught By any self-styled lords of the age with thee Vexes my modesty, lest they should see I hold them owls and peacocks, things of nought.

And when we sit alone, and as I please I taste thy love's full smile, and can enstate The pleasure of my kingly heart at ease, My thought swims like a ship, that with the weight Of her rich burden sleeps on the infinite seas Becalm'd, and cannot stir her golden freight. 


\section{6}

WHILE yet we wait for spring, and from the dry And blackening east that so embitters March, Well-housed must watch grey fields and meadows parch,

And driven dust and withering snowflake fly; Already in glimpses of the tarnish'd sky

The sun is warm and beckons to the larch, And where the covert hazels interarch Their tassell'd twigs, fair beds of primrose lie.

Beneath the crisp and wintry carpet hid A million buds but stay their blossoming; And trustful birds have built their nests amid The shuddering boughs, and only wait to sing Till one soft shower from the south shall bid, And hither tempt the pilgrim steps of spring. 


\section{7}

IN thee my spring of life hath bid the while

A rose unfold beyond the summer's best,

The mystery of joy made manifest

In love's self-answering and awakening smile;

Whereby the lips in wonder reconcile

Passion with peace, and show desire at rest, -

A grace of silence by the Greek unguesst,

That bloom'd to immortalize the Tuscan style :

When first the angel-song that faith had ken'd Fancy pourtray'd, above recorded oath Of Israel's God, or light of poem pen'd; The very countenance of plighted troth 'Twixt heaven and earth, where in one moment blend The hope of one and happiness of both. 


\section{8}

For beauty being the best of all we know Sums up the unsearchable and secret aims Of nature, and on joys whose earthly names Were never told can form and sense bestow; And man hath sped his instinct to outgo The step of science; and against her shames Imagination stakes out heavenly claims, Building a tower above the head of woe.

Nor is there fairer work for beauty found Than that she win in nature her release From all the woes that in the world abound : Nay with his sorrow may his love increase, If from man's greater need beauty redound, And claim his tears for homage of his peace. 


\section{9}

Thus to thy beauty doth my fond heart look, That late dismay'd her faithless faith forbore; And wins again her love lost in the lore Of schools and script of many a learned book: For thou what ruthless death untimely took Shalt now in better brotherhood restore, And save my batter'd ship that far from shore High on the dismal deep in tempest shook.

So in despite of sorrow lately learn'd I still hold true to truth since thou art true, Nor wail the woe which thou to joy hast turn'd : Nor come the heavenly sun and bathing blue To my life's need more splendid and unearn'd Than hath thy gift outmatch'd desire and due. 


\section{IO}

WINTER was not unkind because uncouth; His prison'd time made me a closer guest, And gave thy graciousness a warmer zest, Biting all else with keen and angry tooth : And bravelier the triumphant blood of youth Mantling thy cheek its happy home possest, And sterner sport by day put strength to test, And custom's feast at night gave tongue to truth.

Or say hath flaunting summer a device To match our midnight revelry, that rang With steel and flame along the snow-girt ice?

Or when we hark't to nightingales that sang On dewy eves in spring, did they entice To gentler love than winter's icy fang ? 


\section{II}

THERE's many a would-be poet at this hour, Rhymes of a love that he hath never woo'd, And o'er his lamplit desk in solitude Deems that he sitteth in the Muses' bower : And some the flames of earthly love devour, Who have taken no kiss of Nature, nor renew'd In the world's wilderness with heavenly food The sickly body of their perishing power.

So none of all our company, I boast, But now would mock my penning, could they see How down the right it maps a jagged coast; Seeing they hold the manlier praise to be Strong hand and will, and the heart best when most 'Tis sober, simple, true, and fancy-free. 


\section{I2}

How could I quarrel or blame you, most dear, Who all thy virtues gavest and kept back none;

Kindness and gentleness, truth without peer, And beauty that my fancy fed upon?

Now not my life's contrition for my fault Can blot that day, nor work me recompence, Tho' I might worthily thy worth exalt, Making thee long amends for short offence.

For surely nowhere, love, if not in thee Are grace and truth and beauty to be found; And all my praise of these can only be A praise of thee, howe'er by thee disown'd :

While still thou must be mine tho' far removed, And I for one offence no more beloved. 


\section{I3}

Now since to me altho' by thee refused

The world is left, I shall find pleasure still;

The art that most I have loved but little used Will yield a world of fancies at my will :

And tho' where'er thou goest it is from me,

I where I go thee in my heart must bear; And what thou wert that wilt thou ever be, My choice, my best, my loved, and only fair.

Farewell, yet think not sucil farewell a change From tenderness, tho' once to meet or part But on short absence so could sense derange That tears have graced the greeting of my heart;

They were proud drops and had my leave to fall, Not on thy pity for my pain to call. 


\section{I4}

WHEN sometimes in an ancient house where state

From noble ancestry is handed on,

We see but desolation thro' the gate,

And richest heirlooms all to ruin gone;

Because maybe some fancied shame or fear,

Bred of disease or melancholy fate,

Hath driven the owner from his rightful sphere

To wander nameless save to pity or hate :

What is the wreck of all he hath in fief, When he that hath is wrecking? nought is fine Unto the sick, nor doth it burden grief That the house perish when the soul doth pine.

Thus I my state despise, slain by a sting So slight 'twould not have hurt a meaner thing. 


\section{OF LOVE}

\section{I5}

WHO builds a ship must first lay down the keel Of health, whereto the ribs of mirth are wed : And knit, with beams and knees of strength, a bed For decks of purity, her floor and ceil. Upon her masts, Adventure, Pride, and Zeal, To fortune's wind the sails of purpose spread : And at the prow make figured maidenhead O'erride the seas and answer to the wheel.

And let him deep in memory's hold have stor'd Water of Helicon : and let him fit The needle that doth true with heaven accord : Then bid her crew, love, diligence and wit With justice, courage, temperance come aboard, And at her helm the master reason sit. 


\section{I6}

THIs world is unto God a work of art, Of which the unaccomplish'd heavenly plan Is hid in life within the creature's heart, And for perfection looketh unto man.

Ah me! those thousand ages: with what slow Pains and persistence were his idols made, Destroy'd and made, ere ever he could know The mighty mother must be so obey'd.

For lack of knowledge and thro' little skill His childish mimicry outwent his aim; His effort shaped the genius of his will; Till thro' distinction and revolt he came, True to his simple terms of good and ill, Seeking the face of Beauty without blame. 


\section{I7}

$S_{A Y}$ who be these light-bearded, sunburnt faces In negligent and travel-stain'd array,

That in the city of Dante come to-day,

Haughtily visiting her holy places?

$\mathrm{O}$ these be noble men that hide their graces,

True England's blood, her ancient glory's stay,

By tales of fame diverted on their way

Home from the rule of oriental races.

Life-trifling lions these, of gentle eyes And motion delicate, but swift to fire For honour, passionate where duty lies, Most loved and loving: and they quickly tire Of Florence, that she one day more denies The embrace of wife and son, of sister or sire. 


\section{I8}

Where San Miniato's convent from the sun At forenoon overlooks the city of flowers I sat, and gazing on her domes and towers Call'd up her famous children one by one: And three who all the rest had far outdone, Mild Giotto first, who stole the morning hours, I saw, and god-like Buonarroti's powers, And Dante, gravest poet, her much-wrong'd son.

Is all this glory, I said, another's praise? Are these heroic triumphs things of old, And do I dead upon the living gaze? Or rather doth the mind, that can behold The wondrous beauty of the works and days, Create the image that her thoughts enfold? 


\section{I9}

Rejorce, ye dead, where'er your spirits dwell, Rejoice that yet on earth your fame is bright; And that your names, remember'd day and night, Live on the lips of those that love you well. 'Tis ye that conquer'd have the powers of hell, Each with the special grace of your delight : Ye are the world's creators, and thro' might Of everlasting love ye did excel.

Now ye are starry names, above the storm And war of Time and nature's endless wrong Ye flit, in pictured truth and peaceful form, Wing'd with bright music and melodious song,-

The flaming flowers of heaven, making May-dance In dear Imagination's rich pleasance. 


\section{0}

THE world still goeth about to shew and hide, Befool'd of all opinion, fond of fame : But he that can do well taketh no pride, And see'th his error, undisturb'd by shame :

So poor's the best that longest life can do, The most so little, diligently done; So mighty is the beauty that doth woo, So vast the joy that love from love hath won.

God's love to win is easy, for He loveth Desire's fair attitude, nor strictly weighs The broken thing, but all alike approveth Which love hath aim'd atHim: that is heaven's praise:

And if we look for any praise on earth, 'Tis in man's love : all else is nothing worth. 


\section{OF LOVE}

\section{$2 I$}

O FLESH and blood, comrade to tragic pain

And clownish merriment; whose sense could wake Sermons in stones, and count death but an ache, All things as vanity, yet nothing vain :

The world, set in thy heart, thy passionate strain Reveal'd anew; but thou for man didst make Nature twice natural, only to shake Her kingdom with the creatures of thy brain.

Lo, Shakespeare, since thy time nature is loth To yield to art her fair supremacy;

In conquering one thou hast so enrichèd both. What shall I say? for God-whose wise decree Confirmeth all $\mathrm{He}$ did by all $\mathrm{He}$ dothDoubled His whole creation making thee. 


\section{2}

I would be a bird, and straight on wings I arise, And carry purpose up to the ends of the air : In calm and storm my sails I feather, and where By freezing cliffs the unransom'd wreckage lies : Or, strutting on hot meridian banks, surprise The silence : over plains in the moonlight bare I chase my shadow, and perch where no bird dare In treetops torn by fiercest winds of the skies.

Poor simple birds, foolish birds! then I cry, Ye pretty pictures of delight, unstir'd By the only joy of knowing that ye fly;

Ye are not what ye are, but rather, sum'd in a word, The alphabet of a god's idea, and I Who master it, I am the only bird. 


\section{3}

O WEARY pilgrims, chanting of your woe,

That turn your eyes to all the peaks that shine,

Hailing in each the citadel divine

The which ye thought to have enter'd long ago;

Until at length your feeble steps and slow

Falter upon the threshold of the shrine,

And your hearts overburden'd doubt in fine Whether it be Jerusalem or no:

Dishearten'd pilgrims, I am one of you; For, having worshipp'd many a barren face, I scarce now greet the goal I journey'd to:

I stand a pagan in the holy place;

Beneath the lamp of truth I am found untrue, And question with the God that I embrace. 


\section{4}

SPRING hath her own bright days of calm and peace; Her melting air, at every breath we draw, Floods heart with love to praise God's gracious law : But suddenly - so short is pleasure's leaseThe cold returns, the buds from growing cease, And nature's conquer'd face is full of awe; As now the traitrous north with icy flaw Freezes the dew upon the sick lamb's fleece,

And 'neath the mock sun searching everywhere Rattles the crispèd leaves with shivering din : So that the birds are silent with despair Within the thickets; nor their armour thin Will gaudy flies adventure in the air, Nor any lizard sun his spotted skin. 


\section{OF LOVE}

\section{5}

Nothrng is joy without thee : I can find

No rapture in the first relays of spring,

In songs of birds, in young buds opening,

Nothing inspiriting and nothing kind;

For lack of thee, who once wert throned behind All beauty, like a strength where graces cling,-

The jewel and heart of light, which everything Wrestled in rivalry to hold enshrined.

Ah! since thou'rt fled, and $I$ in each fair sight The sweet occasion of my joy deplore, Where shall I seek thee best, or whom invite Within thy sacred temples and adore? Who shall fill thought and truth with old delight, And lead my soul in life as heretofore? 


\section{6}

THE work is done, and from the fingers fall

The bloodwarm tools that brought the labour thro':

The tasking eye that overrunneth all

Rests, and affirms there is no more to do.

Now the third joy of making, the sweet flower

Of blessed work, bloometh in godlike spirit;

Which whoso plucketh holdeth for an hour

The shrivelling vanity of mortal merit.

And thou, my perfect work, thou'rt of to-day;

To-morrow a poor and alien thing wilt be,

True only should the swift life stand at stay:

Therefore farewell, nor look to bide with me.

Go find thy friends, if there be one to love thee;

Casting thee forth, my child, I rise above thee. 


\section{7}

THE fabled seasnake, old Leviathan,

Or else what grisly beast of scaly chine

That champ'd the oceanwrack and swash'd the brine,

Before the new and milder days of man,

Had never rib nor bray nor swindging fan

Like his iron swimmer of the Clyde or Tyne,

Late-born of golden seed to breed a line

Of offspring swifter and more huge of plan.

Straight is her going, for upon the sun When once she hath look'd, her path and place are plain;

With tireless speed she smiteth one by one The shuddering seas and foams along the main; And her eased breath, when her wild race is run, Roars thro' her nostrils like a hurricane. 


\section{8}

A THOUSAND times hath in my heart's behoof My tongue been set his passion to impart;

A thousand times hath my too coward heart My mouth reclosed and fix'd it to the roof; Then with such cunning hath it held aloof, A thousand times kept silence with such art That words could do no more : yet on thy part Hath silence given a thousand times reproof.

I should be bolder, seeing I commend Love, that my dilatory purpose primes, But fear lest with my fears my hope should end: Nay I would truth deny and burn my rhymes, Renew my sorrows rather than offend, A thousand times, and yet a thousand times. 


\section{9}

I TRAVEL to thee with the sun's first rays,

That lift the dark west and unwrap the night;

I dwell beside thee when he walks the height,

And fondly toward thee at his setting gaze.

I wait upon thy coming, but always-

Dancing to meet my thoughts if they invite-

Thou hast outrun their longing with delight,

And in my solitude dost mock my praise.

Now doth my drop of time transcend the whole : I see no fame in Khufu's pyramid, No history where loveless Nile doth roll.

- This is eternal life, which doth forbid

Mortal detraction to the exalted soul,

And from her inward eye all fate hath hid. 


\section{0}

My lady pleases me and I please her ; This know we both, and I besides know well Wherefore I love her, and I love to tell My love, as all my loving songs aver. But what on her part could the passion stir, Tho' 'tis more difficult for love to spell, Yet can I dare divine how this befel, Nor will her lips deny it if I err.

She loves me first because I love her, then Loves me for knowing why she should be loved, And that I love to praise her, loves again. So from her beauty both our loves are moved, And by her beauty are sustain'd; nor when The earth falls from the sun is this disproved. 


\section{I}

IN all things beautiful, I cannot see

Her sit or stand, but love is stir'd anew :

'Tis joy to watch the folds fall as they do,

And all that comes is past expectancy.

If she be silent, silence let it be ;

He who would bid her speak might sit and sue

The deep-brow'd Phidian Jove to be untrue

To his two thousand years' solemnity.

$\mathrm{Ah}$, but her launchèd passion, when she sings, Wins on the hearing like a shapen prow Borne by the mastery of its urgent wings : Or if she deign her wisdom, she doth show She hath the intelligence of heavenly things, Unsullied by man's mortal overthrow. 


\section{2}

THus to be humbled: 'tis that ranging pride

No refuge hath; that in his castle strong

Brave reason sits beleaguer'd, who so long

Kept field, but now must starve where he doth hide;

That industry, who once the foe defied,

Lies slaughter'd in the trenches; that the throng

Of idle fancies pipe their foolish song,

Where late the puissant captains fought and died.

Thus to be humbled: 'tis to be undone;

A forest fell'd; a city razed to ground;

A cloak unsewn, unwoven and unspun

Till not a thread remains that can be wound.

And yet, O lover, thee, the ruin'd one,

Love who hath humbled thus hath also crown'd. 


\section{3}

I CARE not if I live, tho' life and breath

Have never been to me so dear and sweet.

I care not if I die, for I could meet-

Being so happy-happily my death.

I care not if I love; to-day she saith

She loveth, and love's history is complete.

Nor care I if she love me; at her feet

My spirit bows entranced and worshippeth.

I have no care for what was most my care,

But all around me see fresh beauty born,

And common sights grown lovelier than they were :

I dream of love, and in the light of morn

Tremble, beholding all things very fair

And strong with strength that puts my strength to scorn. 


\section{4}

O Mr goddess divine sometimes I say :-

Now let this word for ever and all suffice;

Thou art insatiable, and yet not twice

Can even thy lover give his soul away:

And for my acts, that at thy feet I lay;

For never any other, by device

Of wisdom, love or beauty, could entice My homage to the measure of this day.

I have no more to give thee: 1o, I have sold My life, have emptied out my heart, and spent Whate'er I had; till like a beggar, bold With nought to lose, I laugh and am content. A beggar kisses thee; nay love, behold, I fear not: thou too art in beggarment. 


\section{5}

ALL earthly beauty hath one cause and proof,

To lead the pilgrim soul to beauty above:

Yet lieth the greater bliss so far aloof,

That few there be are wean'd from earthly love.

Joy's ladder it is, reaching from home to home,

The best of all the work that all was good;

Whereof 'twas writ the angels aye upclomb,

Down sped, and at the top the Lord God stood.

But I my time abuse, my eyes by day

Center'd on thee, by night my heart on fire-

Letting my number'd moments run away-

Nor e'en 'twixt night and day to heaven aspire:

So true it is that what the eye seeth not But slow is loved, and loved is soon forgot. 


\section{6}

MY life's mischief, once my love's delight,

That drew'st a mortgage on my heart's estate,

Whose baneful clause is never out of date,

Nor can avenging time restore my right:

Whom first to lose sounded that note of spite,

Whereto my doleful days were tuned by fate :

That art the well-loved cause of all my hate,

The sun whose wandering makes my hopeless night:

Thou being in all my lacking all I lack,

It is thy goodness turns my grace to crime, Thy fleetness from my goal which holds me back; Wherefore my feet go out of step with time, My very grasp of life is old and slack, And even my passion falters in my rhyme. 


\section{7}

Aт times with hurried hoofs and scattering dust I race by field or highway, and my horse Spare not, but urge direct in headlong course Unto some fair far hill that gain I must : But near arrived the vision soon mistrust, Rein in, and stand as one who sees the source Of strong illusion, shaming thought to force From off his mind the soil of passion's gust.

My brow I bare then, and with slacken'd speed Can view the country pleasant on all sides, And to kind salutation give good heed: I ride as one who for his pleasure rides, And stroke the neck of my delighted steed, And seek what cheer the village inn provides. 


\section{8}

AN idle June day on the sunny Thames,

Floating or rowing as our fancy led,

Now in the high beams basking as we sped,

Now in green shade gliding by mirror'd stems;

By lock and weir and isle, and many a spot

Of memoried pleasure, glad with strength and skill, Friendship, good wine, and mirth, that serve not ill The heavenly Muse, tho' she requite them not:

I would have life-thou saidst-all as this day, Simple enjoyment calm in its excess, With not a grief to cloud, and not a ray Of passion overhot my peace to oppress; With no ambition to reproach delay, Nor rapture to disturb its happiness. 


\section{9}

A MAN that sees by chance his picture, made As once a child he was, handling some toy, Will gaze to find his spirit within the boy, Yet hath no secret with the soul pourtray'd : He cannot think the simple thought which play'd Upon those features then so frank and coy; 'Tis his, yet oh! not his : and o'er the joy His fatherly pity bends in tears dismay'd.

Proud of his prime maybe he stand at best, And lightly wear his strength, or aim it high, In knowledge, skill and courage self-possest :Yet in the pictured face a charm doth lie, The one thing lost more worth than all the rest, Which seeing, he fears to say This child was $I$. 


\section{0}

TEars of love, tears of joy and tears of care,

Comforting tears that fell uncomforted,

Tears o'er the new-born, tears beside the dead,

Tears of hope, pride and pity, trust and prayer,

Tears of contrition; all tears whatsoe'er

Of tenderness or kindness had she shed

Who here is pictured, ere upon her head

The fine gold might be turn'd to silver there.

The smile that charm'd the father hath given place Unto the furrow'd care wrought by the son; But virtue hath transform'd all change to grace : So that I praise the artist, who hath done A portrait, for my worship, of the face Won by the heart my father's heart that won. 


\section{$4 \mathrm{I}$}

IF I could but forget and not recall

So well my time of pleasure and of play,

When ancient nature was all new and gay,

Light as the fashion that doth last enthrall,Ah mighty nature, when my heart was small, Nor dream'd what fearful searchings underlay The flowers and leafy ecstasy of May, The breathing summer sloth, the scented fall:

Could I forget, then were the fight not hard, Press'd in the melée of accursed things, Having such help in love and such reward: But that 'tis I who once-'tis this that stingsOnce dwelt within the gate that angels guard, Where yet I'd be had I but heavenly wings. 


\section{2}

WHEN I see childhood on the threshold seize The prize of life from age and likelihood, I mourn time's change that will not be withstood, Thinking how Christ said Be like one of these. For in the forest among many trees Scarce one in all is found that hath made good The virgin pattern of its slender wood, That courtesied in joy to every breeze;

But scath'd, but knotted trunks that raise on high Their arms in stiff contortion, strain'd and bare; Whose patriarchal crowns in sorrow sigh. So, little children, ye-nay nay, ye ne'er From me shall learn how sure the change and nigh, When ye shall share our strength and mourn to share. 


\section{3}

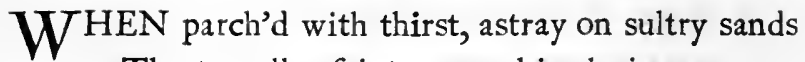
The traveller faints, upon his closing ear

Steals a fantastic music: he may hear

The babbling fountain of his native land.

Before his eyes the vision seems to stand, Where at its terraced brink the maids appear, Who fill their deep urns at its waters clear, And not refuse the help of lover's hand.

O cruel jest-he cries, as some one flings The sparkling drops in sport or shew of ireO shameless, $O$ contempt of holy things. But never of their wanton play they tire, As not athirst they sit beside the springs, While he must quench in death his lost desire. 


\section{4}

THE image of thy love, rising on dark And desperate days over my sullen sea, Wakens again fresh hope and peace in me, Gleaming above upon my groaning bark. Whate'er my sorrow be, I then may hark A loving voice: whate'er my terror be, This heavenly comfort still I win from thee, To shine my lodestar that wert once my mark.

Prodigal nature makes us but to taste One perfect joy, which given she niggard grows; And lest her precious gift should run to waste, Adds to its loss a thousand lesser woes : So to the memory of the gift that graced Her hand, her graceless hand more grace bestows. 


\section{5}

IN this neglected, ruin'd edifice

Of works unperfected and broken schemes,

Where is the promise of my early dreams,

The smile of beauty and the pearl of price?

No charm is left now that could once entice

Wind-wavering fortune from her golden streams,

And full in flight decrepit purpose seems,

Trailing the banner of his old device.

Within the house a frore and numbing air Has chill'd endeavour : sickly memories reign In every room, and ghosts are on the stair : And hope behind the dusty window-pane Watches the days go by, and bow'd with care Forecasts her last reproach and mortal stain. 


\section{6}

ONCE I would say, before thy vision came, My joy, my life, my love, and with some kind Of knowledge speak, and think I knew my mind Of heaven and hope, and each word hit its aim. Whate'er their sounds be, now all mean the same, Denoting each the fair that none can find; . Or if I say them, 'tis as one long blind Forgets the sights that he was used to name.

Now if men speak of love, 'tis not my love; Nor are their hopes nor joys mine, nor their life Of praise the life that I think honour of: Nay tho' they turn from house and child and wife And self, and in the thought of heaven above Hold, as do I, all mortal things at strife. 


\section{7}

SINCE then 'tis only pity looking back,

Fear looking forward, and the busy mind

Will in one woeful moment more upwind

Than lifelong years unroll of bitter or black;

What is man's privilege, his hoarding knack

Of memory with foreboding so combined,

Whereby he comes to dream he hath of kind

The perpetuity which all things lack?

Which but to hope is doubtful joy, to have Being a continuance of what, alas, We mourn, and scarcely bear with to the grave;

Or something so unknown that it o'erpass

The thought of comfort, and the sense that gave

Cannot consider it thro' any glass. 


\section{8}

Come gentle sleep, I woo thee : come and take Not now the child into thine arms, from fright Composed by drowsy tune and shaded light, Whom ignorant of thee thou didst nurse and make; Nor now the boy, who scorn'd thee for the sake Of growing knowledge or mysterious night, 'Tho' with fatigue thou didst his limbs invite, And heavily weigh the eyes that would not wake;

No, nor the man severe, who from his best Failing, alert fled to thee, that his breath, Blood, force and fire should come at morn redrest; But me, from whom thy comfort tarrieth, For all my wakeful prayer sent without rest To thee, $\mathrm{O}$ shew and shadow of my death. 


\section{9}

$T^{H E}$ spirit's eager sense for sad or gay

Filleth with what he will our vessel full :

Be joy his bent, he waiteth not joy's day,

But like a child at any toy will pull :

If sorrow, he will weep for fancy's sake, And spoil heaven's plenty with forbidden care. What fortune most denies we slave to take; Nor can fate load us more than we can bear.

Since pleasure with the having disappeareth, He who hath least in hand hath most at heart, While he keep hope : as he who alway feareth A grief that never comes hath yet the smart; And heavier far is our self-wrought distress, For when God sendeth sorrow, it doth bless. 


\section{0}

THE world comes not to an end : her city-hives Swarm with the tokens of a changeless trade, With rolling wheel, driver and flagging jade, Rich men and beggars, children, priests and wives. New homes on old are set, as lives on lives; Invention with invention overlaid: But still or tool or toy or book or blade Shaped for the hand, that holds and toils and strives.

The men to-day toil as their fathers taught, With little better'd means; for works depend On works and overlap, and thought on thought : And thro' all change the smiles of hope amend The weariest face, the same love changed in nought : In this thing too the world comes not to an end. 


\section{SI}

$\mathrm{O} M \mathrm{Y}$ uncared-for songs, what are ye worth, That in my secret book with so much care I write you, this one here and that one there, Marking the time and order of your birth? How, with a fancy so unkind to mirth, A sense so hard, a style so worn and bare, Look ye for any welcome anywhere From any shelf or heart-home on the earth ?

Should others ask you this, say then I yearn'd To write you such as once, when I was young, Finding I should have loved and thereto turn'd. 'Twere something yet to live again among The gentle youth beloved, and where I learn'd My art, be there remember'd for my song. 


\section{2}

WHo takes the census of the living dead,

Ere the day come when memory shall o'ercrowd The kingdom of their fame, and for that proud And airy people find no room nor stead?

Ere hoarding Time, that ever thrusteth back The fairest treasures of his ancient store, Better with best confound, so he may pack His greedy gatherings closer, more and more?

Let the true Muse rewrite her sullied page, And purge her story of the men of hate, That they go dirgeless down to Satan's rage With all else foul, deform'd and miscreate :

She hath full toil to keep the names of love Honour'd on earth, as they are bright above. 


\section{3}

I HEARD great Hector sounding war's alarms, Where thro' the listless ghosts chiding he strode, As tho' the Greeks besieged his last abode, And he his Troy's hope still, her king-at-arms. But on those gentle meads, which Lethe charms With weary oblivion, his passion glow'd Like the cold night-worm's candle, and only show'd Such mimic flame as neither heats nor harms.

'Twas plain to read, even by those shadows quaint, How rude catastrophe had dim'd his day, And blighted all his cheer with stern complaint : To arms! to arms! what more the voice would say Was swallow'd in the valleys, and grew faint Upon the thin air, as he pass'd away. 


\section{4}

SINCE not the enamour'd sun with glance more fond Kisses the foliage of his sacred tree,

Than doth my waking thought arise on thee, Loving none near thee, like thee nor beyond; Nay since I am sworn thy slave, and in the bond Is writ my promise of eternity;

Since to such high hope thou'st encouraged me, That if thou look but from me I despond;

Since thou'rt my all in all, $O$ think of this : Think of the dedication of my youth: Think of my loyalty, my joy, my bliss : Think of my sorrow, my despair and ruth, My sheer annihilation if I miss : Think_-if thou shouldst be false-think of thy truth. 


\section{OF LOVE}

\section{5}

THESE meagre rhymes, which a returning mood Sometimes o'errateth, I as oft despise; And knowing them illnatured, stiff and rude, See them as others with contemptuous eyes. Nay, and I wonder less at God's respect For man, a minim jot in time and space, Than at the soaring faith of His elect, That gift of gifts, the comfort of His grace.

$\mathrm{O}$ truth unsearchable, $\mathrm{O}$ heavenly love, Most infinitely tender, so to touch The work that we can meanly reckon of: Surely-I say-we are favour'd overmuch. But of this wonder, what doth most amaze Is that we know our love is held for praise. 


\section{6}

BEAUTY sat with me all the summer day, Awaiting the sure triumph of her eye; Nor mark'd I till we parted, how, hard by, Love in her train stood ready for his prey. She, as too proud to join herself the fray, Trusting too much to her divine ally, When she saw victory tarry, chid him_- Why Dost thou not at one stroke this rebel slay?'

Then generous Love, who holds my heart in fee, Told of our ancient truce : so from the fight We straight withdrew our forces, all the three. Baffled but not dishearten'd she took flight Scheming new tactics: Love came home with me, And prompts my measured verses as I write. 


\section{7}

IN autumn moonlight, when the white air wan Is fragrant in the wake of summer hence, 'Tis sweet to sit entranced, and muse thereon In melancholy and godlike indolence :

When the proud spirit, lull'd by mortal prime To fond pretence of immortality, Vieweth all moments trom the birth of time, All things whate'er have been or yet shall be.

And like the garden, where the year is spent, The ruin of old life is full of yearning, Mingling poetic rapture of lament With flowers and sunshine of spring's sure returning;

Only in visions of the white air wan By godlike fancy seized and dwelt upon. 


\section{8}

WHEN first I saw thee, dearest, if I say

The spells that conjure back the hour and place,

And evermore I look upon thy face,

As in the spring of years long passed away;

No fading of thy beauty's rich array,

No detriment of age on thee I trace,

But time's defeat written in spoils of grace,

From rivals robb'd, whom thou didst pity and slay.

So hath thy growth been, thus thy faith is true, Unchanged in change, still to my growing sense, To life's desire the same, and nothing new: But as thou wert in dream and prescience At love's arising, now thou standst to view In the broad noon of his magnificence. 


\section{OF LOVE}

\section{9}

'TWAS on the very day winter took leave

Of those fair fields I love, when to the skies

The fragrant Earth was smiling in surprise At that her heaven-descended, quick reprieve,

I wander'd forth my sorrow to relieve;

Yet walk'd amid sweet pleasure in such wise As Adam went alone in Paradise, Before God of His pity fashion'd Eve.

And out of tune with all the joy around I laid me down beneath a flowering tree, And o'er my senses crept a sleep profound; In which it seem'd that thou wert given to me, Rending my body, where with hurried sound I feel my heart beat, when I think of thee. 


\section{0}

Love that I know, love I am wise in, love, My strength, my pride, my grace, my skill untaught, My faith here upon earth, my hope above, My contemplation and perpetual thought:

The pleasure of my fancy, my heart's fire, My joy, my peace, my praise, my happy theme, The aim of all my doing, my desire Of being, my life by day, by night my dream:

Love, my sweet melancholy, my distress, My pain, my doubt, my trouble, my despair, My only folly and unhappiness, And in my careless moments still my care :

O love, sweet love, earthly love, love divine, Sayst thou to-day, O love, that thou art mine? 


\section{I}

THE dark and serious angel, who so long Vex'd his immortal strength in charge of me, Hath smiled for joy and fled in liberty To take his pastime with the peerless throng. Oft had I done his noble keeping wrong, Wounding his heart to wonder what might be God's purpose in a soul of such degree; And there he had left me but for mandate strong.

But seeing thee with me now, his task at close He knoweth, and wherefore he was bid to stay, And work confusion of so many foes: The thanks that he doth look for, here I pay, Yet fear some heavenly envy, as he goes Unto what great reward I cannot say. 


\section{2}

I will be what God made me, nor protest Against the bent of genius in my time, That science of my friends robs all the best, While I love beauty, and was born to rhyme.

Be they our mighty men, and let me dwell In shadow among the mighty shades of old, With love's forsaken palace for my cell; Whence I look forth and all the world behold,

And say, These better days, in best things worse, This bastardy of time's magnificence, Will mend in fashion and throw off the curse, To crown new love with higher excellence. Curs'd tho' I be to live my life alone, My toil is for man's joy, his joy my own. 


\section{3}

I LIVE on hope and that I think do all

Who come into this world, and since I see

Myself in swim with such good company,

I take my comfort whatsoe'er befall.

I abide and abide, as if more stout and tall

My spirit would grow by waiting like a tree;

And, clear of others' toil, it pleaseth me

In dreams their quick ambition to forestall.

And if thro' careless eagerness I slide

'To some accomplishment, I give my voice Still to desire, and in desire abide.

I have no stake abroad; if I rejoice In what is done or doing, I confide Neither to friend nor foe my secret choice. 


\section{4}

YE blessed saints, that now in heaven enjoy

The purchase of those tears, the world's disdain,

Doth Love still with his war your peace annoy,

Or hath Death freed you from his ancient pain?

Have ye no springtide, and no burst of May

In flowers and leafy trees, when solemn night

Pants with love-music, and the holy day

Breaks on the ear with songs of heavenly light?

What make ye and what strive for? keep ye thought

Of us, or in new excellence divine

Is old forgot? or do ye count for nought

What the Greek did and what the Florentine?

We keep your memories well : $\mathrm{O}$ in your store

Live not our best joys treasured evermore? 


\section{5}

Aн heavenly joy! But who hath ever heard, Who hath seen joy, or who shall ever find Joy's language? There is neither speech nor word; Nought but itself to teach it to mankind.

Scarce in our twenty thousand painful days We may touch something: but there lives-beyond The best of art, or nature's kindest phaseThe hope whereof our spirit is fain and fond:

The cause of beauty given to man's desires, Writ in the expectancy of starry skies, The faith which gloweth in our fleeting fires, The aim of all the good that here we prize; Which but to love, pursue and pray for well Maketh earth heaven, and to forget it, hell. 


\section{6}

MY wearied heart, whenever, after all,

Its loves and yearnings shall be told complete,

When gentle death shall bid it cease to beat,

And from all dear illusions disenthrall :

However then thou shalt appear to call

My fearful heart, since down at others' feet

It bade me kneel so oft, I'll not retreat

From thee, nor fear before thy feet to fall.

And I shall say, ' Receive this loving heart Which err'd in sorrow only; and in sin Took no delight; but being forced apart From thee, without thee hoping thee to win, Most prized what most thou madest as thou art On earth, till heaven were open to enter in.' 


\section{7}

DREARY was winter, wet with changeful sting Of clinging snowfall and fast-flying frost; And bitterer northwinds then withheld the spring, That dallied with her promise till 'twas lost.

A sunless and half-hearted summer drown'd The flowers in needful and unwelcom'd rain; And Autumn with a sad smile fled uncrown'd From fruitless orchards and unripen'd grain.

But could the skies of this most desolate year In its last month learn with our love to glow, Men yet should rank its cloudless atmosphere Above the sunsets of five years ago :

Of my great praise too part should be its own, Now reckon'd peerless for thy love alone. 


\section{8}

AWAy now, lovely Muse, roam and be free : Our commerce ends for aye, thy task is done: Tho' to win thee I left all else unwon, Thou, whom I most have won, art not for me. My first desire, thou too foregone must be, Thou too, $\mathrm{O}$ much lamented now, tho' none Will turn to pity thy forsaken son, Nor thy divine sisters will weep for thee.

None will weep for thee : thou return, O Muse, To thy Sicilian fields : I once have been On thy loved hills, and where thou first didst use Thy sweetly balanced rhyme, $O$ thankless queen, Have pluck'd and wreath'd thy flowers; but do thou choose Some happier brow to wear thy garlands green. 


\section{9}

Eternal Father, who didst all create,

In whom we live, and to whose bosom move,

To all men be Thy name known, which is Love,

Till its loud praises sound at heaven's high gate.

Perfect Thy kingdom in our passing state,

That here on earth Thou mayst as well approve

Our service, as Thou ownest theirs above,

Whose joy we echo and in pain await.

Grant body and soul each day their daily bread : And should in spite of grace fresh woe begin, Even as our anger soon is past and dead Be Thy remembrance mortal of our sin :

By Thee in paths of peace Thy sheep be led, And in the vale of terror comforted. 



\section{NOTES}




\section{NOTE ON EROS AND PSYCHE.}

This Poem is in all essentials a faithful translation of Apuleius' story, the chief differences being that first, in the way of form, I have, for the sake of balance and contrast, chosen to lengthen the introductory portion; I have also located the story in Crete, and this gives rise to occasional description. -The description of the sunset on p. 83 is a portrait of the phenomena which followed the great eruption of Krakatoa.-Secondly, in the way of ethic I have made a gentler characterization of Psyche, who deserves more care in handling the motives of her conduct than was perhaps felt in Apuleius' time and country.

The acrostic on p. 102 is a remnant of my original dedication. In the first edition there was a note acknowledging the frequent translations from the Greek, and other robberies : and in the second, in which $I$ altered the spelling, I gave my reasons for that, in so far as it is unusual. These reasons 
I need not repeat here, especially as the spelling is not at all as 1 should wish to see it. I advocate liberty in these matters instead of the conventional tyranny. But I will add here that the main inconsistencies of the punctuation are owing to this volume being a reprint of three separate books. The stops are intended solely for the readers' convenience; and almost anything is better than the regulations of a methodic punctuation, which by assuming the possibility of indicating all the varieties of grammatical structure and rhythmic pause by four symbols, cannot be applied without perpetual vexation and injury.

\section{NOTE ON THE GROWTH OF LOVE.}

It was not my wish or intention to offer these sonnets to the public, but since they have been published in America without my permission, and some of them have appeared in collections of poetry in this country, and have been mentioned in professional criticism, I have thought it wise to come to their rescue, and include them in this edition of my poems; to which end I have, while this volume was in the press, revised them; cutting out ten, and amending the worst places in others where I could. 
As they now stand they still make an imperfect poem, but one for which I need not further apologize. Note on Sonnet XIX.-The octett forms part of my 'Purcell Commemoration Ode,' published as No. 2 of Elkin Mathews' 'Shilling Garland,' 1896, and set to music by Dr. Hubert Parry.

$X X X V$. The argument is partly from Michael Angelo's Madrigal xix.

LXIII. Partly from the a nonymous sonnet No. 3793 in the Libro reale, ' Io vivo di speranza.'

$L X I V$. The first quatrain from Michael Angelo's Madrigal, 'Beati voi.'

LXVII. 'The sunsets of five years ago,' which happen to be described on p. 83 of this volume.

R. B.

1898. 

This book is due on the last date stamped below.

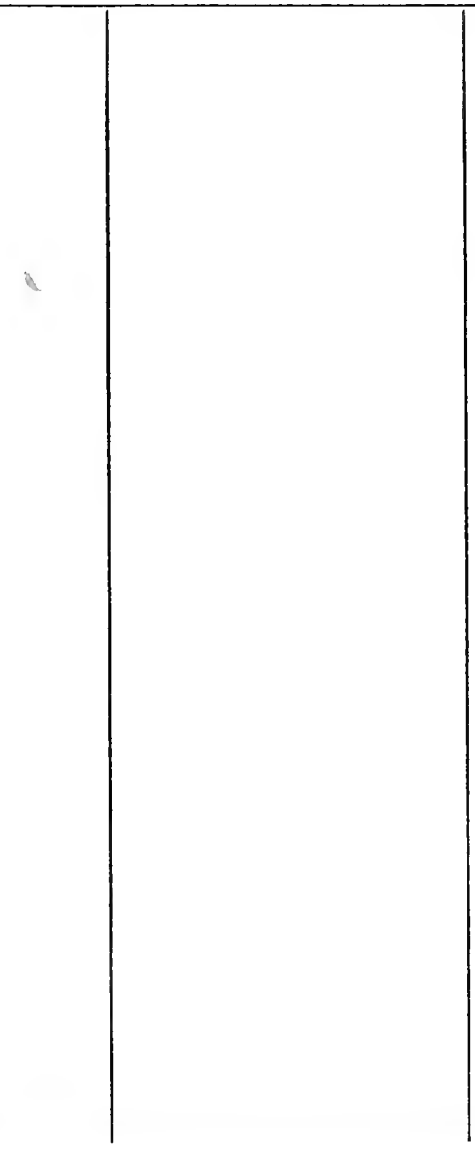




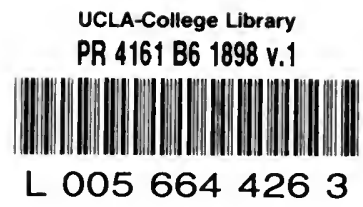

College

Library

PR

4161

B6

1898

v.I

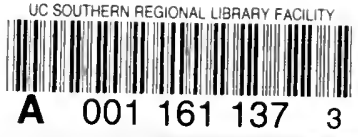


